\title{
Adjudication as Representation
}

Christopher J. Peters

University of Baltimore School of Law, cpeters@ubalt.edu

Follow this and additional works at: http://scholarworks.law.ubalt.edu/all_fac

Part of the Common Law Commons, and the Legislation Commons

\section{Recommended Citation}

Adjudication as Representation, 97 Colum. L. Rev. 312 (1997)

This Article is brought to you for free and open access by the Faculty Scholarship at ScholarWorks@University of Baltimore School of Law. It has been accepted for inclusion in All Faculty Scholarship by an authorized administrator of ScholarWorks@University of Baltimore School of Law. For more information, please contact snolan@ubalt.edu. 


\title{
ADJUDICATION AS REPRESENTATION
}

\author{
Christopher J. Peters*
}

This Article sets forth an interpretive theory of adjudicative lawmaking according to which, under certain conditions, such lawmaking ensures constructive participation through interest representation and thus is not inherently nondemocratic. The author contends that the idea of "judicial activism," courts deciding issues better left to political processes or substituting the personal "values" of judges for law, is based on the incorrect assumptions that courts are unconstrained and nonrepresentative. Instead, when adjudication operates in an archetypal way, it produces law in a manner similar to the parliamentary legislation process. Courts making law are constrained by the process of participatory decisionmaking - the production of judicial decisions through voluntary, self-directed debate among litigants. Moreover, adjudicative lawmaking occurs through the operation of interest representation-the binding of subsequent parties by precedent only to the extent that they are similarly situated to the original parties. The conditions necessary for adjudicative lawmaking to function democratically are that litigants participate to a significant degree in the production of binding decisions, that precedential decisions bind only future parties who are similarly situated to the parties to the original action, and that the conduct of the original litigants meet at least a threshold standard of adequacy. The author examines adjudicative lawmaking from the perspective of proceduralist and functionalist democratic justificatory theories and then demonstrates, using case law and current controversies, that a threat to adjudicative legitimacy arises when the potential binding effects of a decision extend beyond its particular facts. The author concludes that in our concern over judicial decisionmaking, we should monitor the decisionmaking processes used by courts to ensure that adjudication follows or simulates common law processes, thus rendering it democratically legitimate.

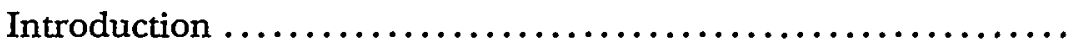

I. The Legitimacy of Democratic Lawmaking ........... 320

A. Proceduralism: Legitimacy Through Process ........ 323

B. Functionalism: Legitimacy Through Results ........ 330

C. Participation and Representation ............... 338

II. The Legitimacy of Adjudicative Lawmaking: Adjudication

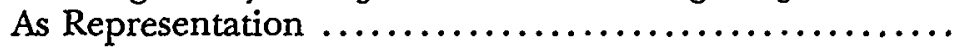

A. Participatory Adjudicative Decisionmaking ............

B. Interest Representation Through the Common Law Method....................................

* Bigelow Teaching Fellow and Lecturer in Law, The University of Chicago Law School. For their invaluable comments on earlier drafts, discussion with me of the issues considered here, and general support, I thank Glenn Butterton, Dick Craswell, Peter DeChiara, Richard Epstein, James Hopenfeld, Dan Kahan, Steve Lawson, John Lott, Jennifer Sachs, David Strauss, Cass Sunstein, and Lloyd Weinreb. 
C. Adjudication As Representation: Three Necessary

Conditions.................................... 374

III. Adjudication As Representation in Action ............ 378

A. Adjudication As Representation in a String of

Common Law Cases ........................... 379

B. Adjudication As Representation in Statutory and

Constitutional Cases ...........................

391

IV. The Theory of Adjudication As Representation: Some

Topical Applications (and Some Surprising Implications) .

A. The Debate Over Legal Rules .................. 401

B. Judicial Review............................. 411

C. Justiciability Doctrines....................... 420

Conclusion: Adjudication As Representation and "Judicial

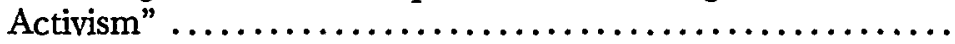

\section{INTRODUCTION}

The Constitution preserves our liberties by providing that all of those given the authority to make policy are directly accountable to the people through regular elections. ... But ... judges are, as they must be to perform their vital role, unelected, unaccountable, and unrepresentative ....

Robert Bork ${ }^{1}$

The democratic integrity of law ... depends entirely upon the degree to which its processes are legitimate.

Robert Bork ${ }^{2}$

It is something of a risk to begin an article with two quotations from Robert Bork's book The Tempting of America; people might make assumptions about one's jurisprudence or one's politics. I have taken the risk for two related reasons. First, these particular quotations nicely frame, in a point-counterpoint fashion, the issues I want to discuss in this Article. Second, Judge Bork's book itself stands as one of the most salient recent examples of a prevalent, fundamental, almost instinctive belief about adjudication that it is my core project to undermine here.

That belief, which is implied by the first quotation excerpted above, is this: that courts act in an inherently nondemocratic way when they make law (or when they invalidate law created through supposedly more democratic means-the phenomenon with which The Tempting of America is chiefly concerned). If courts inherently act nondemocratically when they

1. Robert H. Bork, The Tempting of America 4-5 (1990); see also Vander Jagt v. O'Neill, 699 F.2d 1166, 1178-79 (D.C. Cir. 1983) (Bork, J., concurring) ("All of the doctrines that cluster about Article III ... relate in part . . . to an idea, which is more than an intuition but less than a rigorous and explicit theory, about the constitutional and prudential limits to the powers of an unelected, unrepresentative judiciary in our kind of government.").

2. Bork, supra note 1 , at 2 . 
legislate, then, in a polity in which lawmaking is supposed to be democratic, courts inherently act illegitimately when they do so, to some extent at least. My primary goal in this Article is to demonstrate that the assumption of adjudicative lawmaking's inherent nondemocracy is, in an important way, quite wrong, and that the conclusion of illegitimacy therefore cannot be drawn from it. Courts need not act nondemocratically when they make law, and so we need not worry quite so much about whether they act legitimately when they make it.

The second quotation from Judge Bork's book, on the other hand, expresses on its face what could be considered the underlying premise of this Article: "The democratic integrity of law . . . depends entirely upon the degree to which its processes are legitimate." 3 The quotation seems to suggest that from the standpoint of democracy (and this is a key qualifier), laws have legitimate authority if, and only to the extent that, they are created in a "democratic" way-through "legitimate processes"-without regard to what the laws actually say or do. As the reader will discover, this premise forms a crucial foundation for the conclusions I will draw here.

I am afraid, however, that Judge Bork intends his statement to convey a rather different idea than this. Bork goes on to explain what he means by "legitimate processes":

A judge who announces a decision must be able to demonstrate that he began from recognized legal principles and reasoned in an intellectually coherent and politically neutral way to his result. Those who would politicize the law offer the public, and the judiciary, the temptation of results without regard to democratic legitimacy. 4

As this passage reveals, Bork is not concerned with the democratic legitimacy of the lawmaking processes that judges use; indeed, as I have hinted already, Bork believes that any sort of judicial creation of law is inherently illegitimate from the standpoint of democracy, that when courts make law, "[a] judge has begun to rule where a legislator should." ${ }^{5}$ Bork is concerned in this excerpt, rather, with preserving a certain conception of the proper judicial function by maintaining the separation between judicial lawmaking and judicial law-declaring. Lawmaking, Bork believes, is what elected legislatures do in a democracy. In contrast, courts simply declare what the law already is by "beg[inning] from recognized legal principles and reason [ing] in an intellectually coherent and politically neutral way" to reach a preordained result. 6

What Judge Bork's account fails to recognize is that the same kinds of "processes" that make the activity of the "legislator" legitimate in a democracy, that justify democratic parliamentary legislation, also can make
3. Id.
4. Id.
5. Id. at 1 .
6. Id. at 2. 
adjudicative lawmaking legitimate in a similar way. When the right kind of process is in place, adjudication need not be thought of as inherently nondemocratic, and thus the tenuous distinction between lawmaking and law-declaring need not be clung to so desperately in order to preserve adjudicative legitimacy. That is the fundamental message of this Article.

The salient fact that will animate my discussion here is simply that, despite Judge Bork's wishes, courts do make laws (or, if you prefer, rules) that govern us-that adjudicative lawmaking is, as Cardozo remarked, "one of the existing realities of life."7 My project will be to offer a democratic justification of this reality, one that proceeds from a descriptive account of how adjudication typically functions. As such, my project differs dramatically from that of Judge Bork, who is concerned not with justifying adjudicative lawmaking but with denying that it is capable of justification.

Adjudicative lawmaking 8 occurs in two basic types of circumstances. First, courts make law, in Holmes's phrase, "interstitially"9-acting not on a grand scale, but moving rather "from molar to molecular motions," 10 by filling in gaps where the legislature cannot act, has not yet acted, or has acted only ambiguously. Virtually everyone concedes that necessity legitimizes courts' rulemaking within such gaps ${ }^{11}$ (although not everyone agrees that it is rulemaking rather than rule-declaring that courts are doing

7. Benjamin N. Cardozo, The Nature of the Judicial Process 10 (1921).

8. I try to avoid the phrase "judicial lawmaking" because, as I hope to make clear, the law produced by courts is authored in large part by the litigants themselves through the adjudicative process, and to somewhat less significant a degree by judges than is commonly assumed. See infra Part II.A.

9. Southern Pac. Co. v. Jensen, 244 U.S. 205, 221 (1917) (Holmes, J., dissenting).

10. Id.

11. The idea of courts as gap-fillers, stepping in to create law in specific circumstances where the legislature cannot efficiently act, began at least with Aristotle, who wrote in the Nicomachean Ethics:

[A]ll law is universal, but in some areas no universal rule can be correct . . . . Hence whenever the law makes a universal rule, but in this particular case ... the legislator falls short, and has made an error by making an unconditional rule... it is correct to rectify the deficiency... [ [by doingl what the legislator would have said himself if he had been present there, and what he would have prescribed, had he known, in his legislation.

Aristotle, Nicomachean Ethics 144-45 (Terence Irwin trans., Hackett Publ'g Co. 1985). Similarly, in the Rhetoric, Aristotle wrote of the criminal law:

[T] here are two kinds of right and wrong conduct towards others, one provided for by written ordinances, the other by unwritten. ... [The latter kind] makes up for the defects of a community's written code of law. . . . Its existence partly is and partly is not intended by legislators ... intended, where they find themselves unable to define things exactly, and are obliged to legislate as if that held good always which in fact only holds good usually; or where it is not easy to be complete owing to the endless possible cases presented .... [A] lifetime would be too short to make out a complete list of these [cases]. If, then, a precise statement is impossible and yet legislation is necessary, the law must be expressed in wide terms....

Aristotle, Rhetoric 80 (W. Rhys Roberts trans., Random House 1st ed. 1954). 
there). Legislatures, after all, can neither predict every future situation that will require the application of a rule nor formulate rules both comprehensive and specific enough to cover all situations. Inevitably a great many disputes will arise that are not clearly and noncontroversially governed by an existing statute. Courts are needed to decide these disputes as they appear-that is, to establish rules (however tentative) to govern them, at least until the legislature steps in with a different rule.

Second, courts make law when they invalidate statutes or other acts of democratically elected bodies as contrary to values or standards that have been agreed in advance to be fundamental rules of the polity-that is, on the ground that they are unconstitutional. Although debate rages over just how, when, and to what extent this checking power should be exercised, no one seriously contends anymore that the power does not or should not exist. ${ }^{12}$ It is difficult to deny that some process independent of ordinary politics is needed to define constitutional values or standards and to correct democratic legislation when it fails to accord with them. Courts, because they are supposed to be much less subject to political pressures than legislatures and to make decisions in a very different way than legislatures do, are thought to be particularly well-suited to these twin functions of definition and correction. As Judge Bork asserts, "[f]ederal judges, alone among our public officials, are given life tenure precisely so that they will not be accountable to the people." 13

Adjudicative lawmaking, then, typically is justified as necessary for two purposes: to fill legislative gaps and to check legislative excesses. We tend to accept both justifications grudgingly, and with some angst. Both, after all, assume significant pathologies in the process of democratic legislation. Either the majoritarian legislature is undereffective because it can

Others who have acknowledged the necessity of courts (or similar officials) articulating law in the absence of clear legislative direction include writers as diverse as Holmes, see Southern Pacific, 244 U.S. at 221 (Holmes, J., dissenting); John Austin, see John Austin, The Province of Jurisprudence Determined 35-36 (Wilfrid E. Rumble ed., 1995); Cardozo, see Cardozo, supra note 7, at 14-16; Ronald Dworkin, see Ronald Dworkin, Law's Empire 313-17 (1986); Edward Levi, see Edward H. Levi, An Introduction to Legal Reasoning 28-32 (1949); and Justice Scalia, see Antonin Scalia, The Rule of Law As a Law of Rules, 56 U. Chi. L. Rev. 1175, 1182-83 (1989). There are, of course, many more examples.

12. Well, almost no one. Lino Graglia has argued, at least, that the power of judicial review does not come from the Constitution, and although he seems to accept that it is here to stay in some form, he is not happy about that fact. See Lino A. Graglia, In Defense of Judicial Restraint, in Supreme Court Activism and Restraint 135, 137-42 (Stephen C. Halpern \&c Charles M. Lamb eds., 1982).

Acceptance of judicial review was not always the rule. Thomas Jefferson, for instance, disapproved of the practice. See Letter from Thomas Jefferson to Judge Spencer Roane (Sept. 6, 1819), in Thomas Jefferson: Writings 1425, 1425-28 (Merrill D. Peterson ed., 1984) [hereinafter Jefferson, Writings]; Letter from Thomas Jefferson to Thomas Ritchie (Dec. 25, 1820), in Jefferson, Writings, supra, at 1445, 1445-46. Judge John B. Gibson of the Pennsylvania Supreme Court famously argued against it in his dissent in Eakin v. Raub, 12 Serg. \& Rawle 330, 346-58 ( $\mathrm{Pa} .1825$ ) (Gibson, J., dissenting).

13. Bork, supra note 1 , at 5 . 
act only generally and cannot anticipate every contingency that might arise, or it is all too effective, threatening to overwhelm the rights of the minority or to undermine some other basic tenet of the polity. In either case it is, paradoxically, precisely the nondemocratic nature of courts that is assumed to provide their legitimacy. Courts are flexible enough to apply general principles to specific cases in ways the cumbersome legislature cannot; they are neutral enough to recognize and override the momentary passions of the majority in the name of deeper commitments.

This presumed nondemocracy of adjudication thus places adjudicative lawmaking in tension with itself. Such lawmaking is necessary to solve problems with parliamentary legislation, and it can claim some legitimacy through this necessity; but at the same time (and for the same reasons) it is seen as essentially nondemocratic, a perception that worries us greatly. We view adjudicative lawmaking as a necessary evil, and we continue to hold out "democratic" lawmaking-legislation by representatives who are "directly accountable to the people"14_as our ideal. We wish we could rely entirely on the latter.

The traditional anxiety over the perceived nondemocracy of adjudicative lawmaking becomes most salient, at least in the public eye, when charges of something called "judicial activism" are leveled by critics like Judge Bork. No one is really sure just what judicial activism means, or rather everyone who uses the term has a different idea of what it means. ${ }^{15}$

14. Id.

15. See, e.g., Bradley C. Canon, A Framework for the Analysis of Judicial Activism, in Supreme Court Activism and Restraint, supra note 12, at 385, 385-89 (identifying numerous senses in which term "judicial activism" has been used, articulating six "dimensions" along which activism should be assessed, and identifying two "basic concepts of judicial activism" underlying the dimensions: "significant Court-generated change in public policy" and the "perception of illegitimacy"); Arthur S. Miller, In Defense of Judicial Activism, in Supreme Court Activism and Restraint, supra note 12, at 167, 167 (adopting definition of judicial activism as courts' "propensity to intervene in the governing process'") (quoting Robert G. McCloskey, The Modern Supreme Court 338 (1972)); Daniel Novak, Economic Activism and Restraint, in Supreme Court Activism and Restraint, supra note 12 , at $77,77-78$ (defining judicial activism by contrasting it with "judicial selfrestraint," which includes deferences to other branches, lack of "result-orientation," respect for precedent, and avoidance of "political" questions); Marvin Schick, Judicial Activism on the Supreme Court, in Supreme Court Activism and Restraint, supra note 12, at 37,37 (understanding judicial activism as deciding "cases that once upon a time... were thought to be beyond the pale of judicial power"); Harold J. Spaeth \& Stuart H. Teger, Activism and Restraint: A Cloak for the Justices' Policy Preferences, in Supreme Court Activism and Restraint, supra note 12, at 277, 278-79, 282, 287-88, 294 (defining judicial activism as lack of judicial deference, respectively, to regulatory agencies and states, and as increased allowance of access to federal courts); Archibald Cox, The Role of the Supreme Court: Judicial Activism or Self-Restraint?, 47 Md. L. Rev. 118, 121-22 (1987) (describing "extreme" judicial activism as "the belief that law is only policy and that the judge should concentrate on building the good society according to the judge's own vision"); William Wayne Justice, The Two Faces of Judicial Activism, 61 Geo. Wash. L. Rev. 1, 2 (1992) (contrasting two notions of judicial activism: judicial overturning of statutes or precedents based on constitutional values, and implementation of "expansive remedies" by federal courts); Sanford Levinson, Raoul Berger Pleads for Judicial Activism: A Comment, 74 Tex. 
The term, however, seems to me to have two primary connotations which go hand-in-hand (and indeed these are the two senses in which Judge Bork seems most often to use it).

The first connotation of judicial activism is that of courts deciding issues they should not decide, issues that should be left to the "political process"- of courts stepping in where there has been no legislative failure of the kinds described above. On this view, judicial activism occurs when, in the words of Mark Tushnet (himself no critic of judicial activism), a court "substitutes the judgment of unelected judges for those of elected decisionmakers." ${ }^{6}$ This may happen, for instance, when a court elevates to the constitutional level an issue that belongs in the realm of ordinary politics. Bork believes Roe $v$. Wade $e^{17}$ is an example of this kind of usurpation: In that case "the Supreme Court [ ] . . ma[de] abortion a matter of constitutional right, thus largely removing the issue from state legislatures, where it had rested for all of our history." 18 When courts become activist in this way, Judge Bork laments, "a major heresy has entered the American constitutional system."19

The second primary connotation of judicial activism is that of courts implementing their own personal ideology or "values" through their decisions rather than simply declaring what "the law" is. This is what Bork calls "the politicization of the law," 20 the reduction of the law "to a tame instrument of a particular political thrust."21 When a judge allows her personal predilections to dictate her decision, anti-activists contend, she is rejecting legal reasoning itself: "This results-first, premises-to-follow form of legal 'reasoning' is to law what Robert Frost called free verse, 'tennis with the net down.' There are no rules, only passions."22

Underlying both of these senses of political activism is the assumption that courts are fundamentally unconstrained, at least from a practical standpoint, and a corresponding fear of what unconstrained courts might do-a fear, in the spirited words of the anti-activist scholar Lino Graglia, of "tyranny." ${ }^{23}$ Anti-activists claim that courts should leave important decisions to legislators because they are democratically elected,

L. Rev. 773, 776-78 (1996) (contrasting two notions of judicial activism: lack of deference to legislative judgment and expansive interpretation of constitutional text); Mark V. Tushnet, Comment on Cox, 47 Md. L. Rev. 147, 147-53 (1987) (listing and explaining six different meanings of judicial activism: willingness to render advisory opinions; readiness to overturn precedent; substitution of judicial for legislative judgment; constitutional nonoriginalism; support for an activist government; and simple blameworthiness of decisionmaking).

16. Tushnet, supra note 15 , at 149.

17. 410 U.S. 113 (1973).

18. Bork, supra note 1 , at 3 .

19. Id. at 4.

20. Id. at 2.

21. Id. at 3 . 1935)).

22. Id. at 264 (citing Robert Frost, Address at Milton Academy, Milton, Mass. (May 17,

23. Graglia, supra note 12 , at 135 . 
are "directly accountable to the people,"24 and thus cannot get away with acting in ways of which the people disapprove. They argue that courts should refrain from imposing their own values because their values are not subject to oversight by the people. The anti-activists' motivation is a fear of the judiciary's godlike powers "in a nation founded on the revolutionary principle that the people are capable of governing themselves and need not be governed by an elite"; 25 it is a distrust, shared by Learned Hand, of rule by "Platonic Guardians."26

Opponents of judicial activism, then, adopt the traditional assumption that adjudicative lawmaking is essentially nondemocratic. I think this assumption is wrong, at least much of the time, and it is my intention in this Article to demonstrate how it is wrong. My thesis is simply that under certain, paradigmatic conditions, adjudication produces law through a process of representation that is akin, in crucial ways, to the process at work in parliamentary legislation. This adjudicative processwhat I will call adjudication as representation-imbues adjudicative lawmaking with the same kind (although perhaps not the same degree) of "democratic" legitimacy that parliamentary lawmaking possesses; it renders adjudicative lawmaking legitimate in a way that is independent of the needs to fill legislative gaps and to check majoritarian excesses. As such, the existence of adjudication as representation should ease our angst about the prevalence of court-created laws in an ostensibly democratic system. More particularly, recognizing the existence of this form of legitimacy should help us understand and work through some of the more vexing contemporary issues involving adjudication. ${ }^{27}$

I will proceed as follows. In Part I, I will articulate and discuss the two different (but not necessarily incompatible) types of theories offered in support of the legitimacy of democratic government. First are theories that democratic processes have inherent value apart from the substantive quality of the laws produced by them, what I will call proceduralist theories. Second are theories that democracy produces laws of better substantive quality than alternative forms of government, what I will call functionalist theories. Both proceduralist and functionalist theories, I will point out, are characterized by a strong preference for government through the participation of the governed and a correspondingly strong dislike of government by fiat. This distinction is the essence of democratic legitimacy, either from a proceduralist or a functionalist perspective.

24. Bork, supra note 1 , at 5 .

25. Graglia, supra note 12 , at 135 .

26. Learned Hand, The Bill of Rights 73 (1958).

27. I tentatively assess three such "vexing issues" in this Article: the debate over whether courts should articulate general rules, the problem of judicial review, and the issue of how justiciability doctrines should be applied. See infra Part IV. As we will see, these three difficult areas share crucial features that are relevant to the theory I outline here. 
Part I also shows how systems of lawmaking in a representative democracy serve the goal of participatory government on both a proceduralist and a functionalist approach: they do so through the twin mechanisms of electoral coercion and interest representation. The concept of interest representation as a means of ensuring constructive participation, and thus of imbuing laws with democratic legitimacy, will become important in the context of adjudicative lawmaking.

In Part II-the theoretical meat of the Article-I will explain how adjudicative lawmaking can, under certain conditions, claim democratic legitimacy by ensuring constructive participation through interest representation. The process resulting when these conditions are present I will call adjudication as representation. The necessary conditions are essentially those of traditional adjudication in the common law mode: significant litigant participation in the decisionmaking process and fact-specific, case-by-case decisionmaking.

In Part lII, in order to amplify and clarify my description of adjudication as representation, I will offer some basic examples of adjudication as representation in action, looking in some detail at a string of common law cases and then, in a bit less depth, at lines of statutory interpretation cases and constitutional cases. In Part IV, I will briefly examine three current controversies in American adjudication from the perspective of adjudication as representation, with the intent of suggesting ways in which that theory might help us resolve them. Specifically, I will look at the debate about whether courts should articulate general rules, at the issue of the appropriate scope of judicial review, and at the question of whether justiciability doctrines should be strictly or liberally applied. As it turns out, these three issues have some important features in common, and the theory of adjudication as representation has something interesting to say about each of them.

Finally, in the Conclusion, I will take up briefly the subject with which Judge Bork is primarily occupied in his book, so-called "judicial activism." I will offer a conception of judicial activism that, consistent with the theory of adjudication as representation, is more concerned with the procedure by which courts reach decisions than with the substance of the decisions they reach. My discussion here will echo, in the context of adjudication, the theme that Judge Bork himself has sounded in the context of parliamentary legislation: that " $[\mathrm{t}] \mathrm{he}$ democratic integrity of law ... depends entirely upon the degree to which its processes are legitimate." 28

\section{The Legitimacy of Democratic Lawmaking}

[I]n the United States ... [t]he people take part in the making of the laws by choosing the lawgivers .... The people reign 
over the American political world as God rules over the universe. It is the cause and the end of all things; everything rises out of it and is absorbed back into it.

Alexis de Tocqueville $e^{29}$

So Two cheers for Democracy: one because it admits variety and two because it permits criticism.

\section{E.M. Forster 30}

In order to understand how adjudicative lawmaking can be seen as legitimate, as possessing "democratic integrity,"31 in the same way that democratic parliamentary lawmaking can, we must first consider why democratic parliamentary lawmaking itself is seen as legitimate. What basic properties of parliamentary lawmaking legitimize the authority of a democratic regime to coerce its citizens by means of law?

This question has been answered in two different ways, by two different kinds of justificatory theories of democracy. The first kind can be described as proceduralist theories. Proceduralist theories emphasize the value that may be derived from (or, what amounts to the same thing, the evil that may be avoided by) the very process of citizens participating in their government. Proceduralism is indifferent to the substantive decisions produced by a particular governmental arrangement, caring only that, according to some particular substantive moral theory, the procedures used to produce those decisions either are inherently good or promote good effects. Proceduralist justifications of democracy thus locate the value of that form of government not in the quality of the substantive legislation it generates, but rather in the inherent fairness or justice of its system of substantial and equal participation in legislation by the governed.

The second kind of democratic justificatory theory can be described as functionalist theories. Functionalist theories focus on the quality of the substantive governance provided by democracy. They hold that democracy, because of its characteristic aggregation of diverse interests and viewpoints in the decisionmaking process, is a good way (or at least the best possible way) to produce the best substantive rules to govern society. They posit that objectively better decisions are more likely to be generated by a form of government that, like democracy, takes into account the interests and opinions of all of its citizens, than by a form of government that restricts participation to, for instance, a privileged few.

These two kinds of theory, proceduralism and functionalism, ${ }^{32}$ might perhaps better be thought of as tendencies rather than full-blown

29. Alexis de Tocqueville, Democracy in America 60 (George Lawrence trans. \& J.P. Mayer ed., 1969).

30. E.M. Forster, Two Cheers for Democracy 70 (1951).

31. Bork, supra note 1 , at 2 .

32. What I call here "functionalist" and "proceduralist" theories generally correspond to what Robert Bone has called, respectively, "outcome-oriented" and "process-oriented" 
theories, as strains of thought animating the work of many who have written about democracy. Calling them "theories" might be read to imply that they tend to be comprehensive and self-contained, which usually is not the case. More often, several varieties of proceduralism or functionalism-sometimes varieties of both proceduralism and functionalism-appear as themes or assumptions in the work of a single theorist. Indeed, it might sometimes be helpful to think of proceduralism and functionalism more as ways of categorizing goals or ends of democracy than as independent ways to justify democracy; this will help explain accounts of democracy that justify it by reference both to procedural and to functional values.

For the same reasons, proceduralism and functionalism should not be seen as mutually exclusive. They are not necessarily so, as my discussion of them below will make clear-although they may be so, depending upon the variety of proceduralism or functionalism to which one adheres. And, as this Article proceeds, it will be important to remember that in one sense both proceduralism and functionalism are "procedural," or process-based, theories of legitimacy. This is because, although the goals of each theory are different, the theories share an exclusive focus on the decisionmaking processes used to reach those goals.

Let me describe briefly what I mean by this. As we shall see, functionalism cares about results, about outcomes, about the substantive quality of government decisions, but it cares about them only in a general sense. Functionalism does not assess the democratic legitimacy of a particular decision by asking whether the substantive outcome of that decision is good or bad. Such teleological assessment is the project of moral theories that exist apart from theories of democracy: egalitarian theories, for instance, or utilitarian theories, or rights-based theories.

Rather, functionalism, like proceduralism, measures the democratic legitimacy of a particular decision according to the process that was used to produce it. Thus a functionalist democrat would consider a law produced by representatives in a deliberative body who have been elected by universal suffrage to be a democratically legitimate law, regardless of its substance, and would consider a law declared by a dictator or an absolute monarch to be democratically illegitimate, regardless of its substance. Functionalism, like proceduralism, is concerned entirely with whether the processes of decisionmaking are legitimate, not with whether any given decision produced by those processes is legitimate. Its difference from proceduralism lies in the reasons why it believes a certain kind of process to be legitimate, that is, reasons having to do with the quality of the decisions that kind of process tends to produce.

participation theories. Robert G. Bone, Rethinking the "Day in Court" Ideal and Nonparty Preclusion, 67 N.Y.U. L. Rev. 193, 201-02 (1992). By Professor Bone's description, an outcome-oriented theory is any theory that "evaluates participation for wbat it adds to the quality of the outcome," id. at 201, while a process-oriented theory is any theory that "assumes that participation has value apart from its effect on outcome quality." Id. at 202. 
In other words, both strains of democratic justificatory theory, proceduralist and functionalist, justify democracy solely by reference to its decisionmaking processes. (Indeed, it is accurate to say that both strains of theory see democracy as a particular kind of decisionmaking process.) It is just that functionalism values those processes because it believes them to produce good laws, while proceduralism values those processes because it believes them to produce or preserve goods wholly apart from the quality of the laws they create.

Of course, a democratic theorist, functionalist or proceduralist, might believe a particular government decision to be illegitimate because, for instance, its substantive outcome is the violation of rights guaranteed by a constitution. If so, however, the theorist is not claiming the decision to be democratically illegitimate; she is claiming it to be illegitimate by some other criterion or criteria, in this case the explicitly nondemocratic criterion that the decision impairs rights protected by a constitution from ordinary democratic processes. (We might prefer to think of such criteria as metademocratic rather than nondemocratic: they reflect a commitment to democracy on a higher level, that is, to limits on everyday democracy that themselves have been imposed through a democratic, supermajoritarian process of constitutional authorship and amendment.) The theorist is simply asserting that a law that is democratically legitimate can nonetheless be ultimately illegitimate because it violates certain nondemocratic or metademocratic norms. The theorist's criteria of democratic legitimacy still have everything to do with the processes by which the law was produced.

In this Part, I will flesh out the concepts of proceduralist and functionalist theories in a bit more detail. My aim will be fairly simple: to support the largely intuitive notion that both types of theory see the participation of the governed in lawmaking as the core value animating democratic legitimacy. Then I will relate how representative democracy implements the value of participation through two related mechanisms: electoral coercion and interest representation. All of this will set the stage for Part II, where I will offer a theory that adjudicative lawmaking, because it allows constructive participation through interest representation under certain conditions, often can claim democratic legitimacy in the same way that parliamentary lawmaking can.

\section{A. Proceduralism: Legitimacy Through Process}

Another name for positive freedom is self-government.

Frank Michelman ${ }^{33}$

Proceduralist theories of democracy treat the very act of individual control of or consent to the process of government-the very act of indi-

33. Frank I. Michelman, The Supreme Court, 1985 Term-Foreword: Traces of SelfGovernment, 100 Harv. L. Rev. 4, 26 (1986). 
vidual participation in the process of government in some way-as morally valuable. This is what makes such theories proceduralist: They value the process of democracy, because it allows individual participation; but they care little for the end results of democracy, that is, the substantive legislation (and other governmental decisions) produced by it.

Proceduralist theories differ from one another according to the ways in which each believes participation to be morally valuable. Some see participation as valuable in itself, as an expression or necessary corollary of fundamental moral principles. These I will call deontological proceduralist theories, and they come in several colors. Others see participation as valuable because it promotes certain beneficial results (but not results connected with the substantive decisions produced by participatory government). These I will call consequentialist proceduralist theories, and they too appear in more than one variety. ${ }^{34}$ The two categories of proceduralism share a lack of concern with the quality or type of substantive decisions that democratic government produces; they value that form of government on other grounds.

1. Deontological Proceduralism. - Deontological proceduralism values democratic government because of a belief that its participatory process is an inherent good. The dominant strain of deontological proceduralism is autonomy-based proceduralism, which values individual autonomy for its own sake and sees democratic government as a necessary manifestation of that autonomy. Autonomy-based theories hold that individual autonomy is promoted to the degree that individuals are allowed to participate in shaping the world around them and is retarded to the degree that individuals are not allowed to participate in this way. The connection between individual autonomy and democratic government seems rather intuitive, but it will be helpful to examine it a bit here in order to demonstrate the crucial role of participation in autonomy-based theories.

Individual autonomy, or the ability to act free of constraint by others-in Kant's words, to "seek [one's] happiness in whatever way [one] sees fit"35 - has both negative and positive dimensions. Its negative aspect is freedom from constraint by others; its positive aspect is freedom to shape the conditions under which one lives one's life. Autonomybased theories of democracy hold that democratic government promotes both dimensions of freedom. ${ }^{36}$

34. Compare the distinction I have drawn elsewhere between consequentialist and deontological theories of justification. See Christopher J. Peters, Foolish Consistency: On Equality, Integrity, and Justice in Stare Decisis, 105 Yale L.J. 2031, 2039-44 (1996).

35. Immanuel Kant, On the Common Saying: "This May be True in Theory, but it Does Not Apply in Practice," reprinted in Kant: Political Writings 61, 74 (Hans Reiss ed., H.B. Nisbet trans., 2d ed. 1991) (1793) [hereinafter Kant, Theory and Practice].

36. Of course, something that promotes positive freedom necessarily will also promote negative freedom, and vice versa. But it is useful to divide freedom, or autonomy, into these two dimensions to demonstrate the nuanced implications of autonomy-based theory for participatory government. 
Democracy can be said to promote negative freedom in two ways. First, it ensures that no individual will have disproportionate power over her fellow citizens. According to autonomy-based theorists like Locke, Rousseau, and Kant, the crucial problem of human interaction without government-in what each called "the state of nature"37-was the problem of one individual's coercion by another without a neutral authority to which she could appeal. ${ }^{38}$ Locke referred to this as the problem of "every Man's being Judge in his own Case": 39 the strong individual could deprive the weak individual of his freedom ${ }^{40}$ with impunity, because "he who was so unjust as to do his Brother an Injury, will scarce be so just as to condemn himself for it." 41 The cure for "the Inconveniences of the State of Nature" 42 was, of course, government; but not just any kind of government would do. An absolute monarchy, for instance, replicated the problems of a state of nature because it allowed one individual-the monarch-to serve as judge in his own case. ${ }^{43}$ What was required was a system of government in which all agreed to be bound equally with each other-in which, in Kant's words, "no-one can put anyone else under a legal obligation without submitting simultaneously to . . . be put under the same kind of obligation by the other person." 44 This system was democracy-in which every citizen has an equal voice in determining what the laws will be. ${ }^{45}$

Democracy promotes negative freedom in a second way under autonomy-based theories: it transforms every act of government coercion into an act of constraint by the individual's own consent. The essence of democracy is that each individual consents to be ruled "by the will and determination of the majority" 46 - a fair agreement because every individual has an equal chance of being a member of the majority with respect to any given issue. If an individual has consented to rule by the majority,

37. See, e.g., Immanuel Kant, Perpetual Peace: A Philosophical Sketch, excerpted in Kant: Political Writings, supra note 35, at 93, $97 \mathrm{n} *$ [hereinafter Kant, Perpetual Peace]; John Locke, Two Treatises of Government 304, 309-18 (Peter Laslett ed., Cambridge Univ. Press 1963) (1690); Jean Jacques Rousseau, The Social Contract 17 (Willmoore Kendall ed. \& trans., 1954).

38. See Immanuel Kant, The Metaphysics of Morals $\$ 44$, excerpted in Kant: Political Writings, supra note 35, at 131, 137-38 [hereinafter Kant, Metaphysics]; Locke, supra note 37 , at 316-17, 367-69, 374-76; Rousseau, supra note 37, at 6-8, 17.

39. Locke, supra note 37 , at 369.

40. For Locke, freedom was bound up with the idea of property. See, e.g., id. at 327-44.

41. Id. at 316 .

42. Id.

43. See id. at 317-18, 369-74.

44. Kant, Perpetual Peace, supra note 37, at $99 \mathrm{n}$; see also Locke, supra note 37 , at 376 (" $[E]$ very Man, by consenting with others to make one Body Politick under one Government, puts himself under an Obligation to every one of that Society ....").

45. See Kant, Perpetual Peace, supra note 37, at $99 \mathrm{n} *$; Kant, Theory and Practice, supra note 35, at 74-79; Locke, supra note 37, at 374-77.

46. Locke, supra note 37 , at 375 (emphasis omitted). 
she necessarily has consented to whatever particular decisions the majority might make, even if those decisions are harmful to her personal interests, to what Rousseau called her "private will." ${ }^{47}$ Thus her freedom is not really being restricted by government at all: she has acted autonomously in granting her general consent to all specific limitations on her autonomy that government may impose in the future. ${ }^{48}$

Note that both aspects of democracy's promotion of negative freedom incorporate a strong preference for government through participation over government by fiat. Democracy's allowance of an equal voice to each citizen in the creation of the laws supposes that every individual has an opportunity to participate in legislation and that no one individual or group of individuals is allowed to legislate by ukase. Democracy's production of consensual legislation through majority rule supposes that every individual, through participation, has the opportunity to be among the majority with respect to any given issue and that no one individual or group is entitled to permanent majority status.

The other dimension of autonomy, the positive dimension, is freedom to shape the conditions under which one lives one's life. It is fairly clear how a system of democratic government can be thought to promote this aspect of freedom. Part of an individual's life in a polity always will be regulated by government. To the extent the individual can participate in determining what this regulation looks like and the circumstances in which it will take effect, that individual participates in shaping part of her own life. Democracy is a form of government that allows this kind of participation; as such, it promotes the positive autonomy derived from the ability to shape the conditions of one's life.

This line of thinking appears most clearly in Kant, who identifies as an "a priori principle" the principle of "freedom of every member of society as a human being." 49 According to Kant, this principle of freedom

can be expressed in the following formula. No-one can compel me to be happy in accordance with his conception of the welfare of others, for each may seek his happiness in whatever way he sees fit, so long as he does not infringe upon the freedom of others to pursue a similar end which can be reconciled with the freedom of everyone else within a workable general law . . . .50 This vision encompasses a positive notion of autonomy as freedom affirmatively to shape one's life, to "seek ... happiness in whatever way [one] sees fit"51 (as well, of course, as a corresponding negative notion of freedom from constraint by others). For Kant, self-government actuated this

47. Rousseau, supra note 37, at 24.

48. See generally Kant, Metaphysics, supra note 38, $\S \S 43-49$, at 136-43; Kant, Theory and Practice, supra note 35, at 79-87; Locke, supra note 37, ch. VIII, §§ 95-122, at 374-94; Rousseau, supra note 37 , bk. 1 , ch. VI, at 17-21; ch. VI, at 22-27; bk. 4, ch. II, at 168-70.

49. Kant, Theory and Practice, supra note 35, at 74 (emphasis altered).

50. Id.

51. Id. 
kind of positive freedom because it permitted each individual to participate in shaping the rules of conduct that best promoted her own notion of happiness. Kant contrasted self-government with "paternal government," or government by "despotism":

A government might be established on the principle of benevolence towards the people, like that of a father towards his children. Under such a paternal government (imperium paternale), the subjects, as immature children who cannot distinguish what is truly useful or harmful to themselves, would be obliged to behave purely passively and to rely upon the judgement of the head of state as to how they ought to be happy, and upon his kindness in willing their happiness at all. Such a government is the greatest conceivable despotism, i.e. a constitution which suspends the entire freedom of its subjects, who thenceforth have no rights whatsoever. ${ }^{52}$

Democracy for Kant, then, was valuable not only as a solution to the problem of external constraint on freedom, but also as a vehicle for the expression of positive, internal human freedom-the freedom to "seek happiness" however one chooses, to distinguish for oneself "what is truly useful or harmful." 53

Like democracy's promotion of negative autonomy, its promotion of positive autonomy relies upon the availability of individual participation in government. Participation is the only way to effect the individual's positive freedom to shape her own life; its alternative, rule by fiat-no matter how benevolent the head of state-denies this freedom because it inevitably treats individuals as "immature children."

Autonomy-based theories of democracy, then, emphasize how the democratic process of government promotes both negative and positive dimensions of individual autonomy. This process is valuable in itself because it allows the governed to participate in the authorship of the laws that govern them. For this reason autonomy-based theories are proceduralist theories.

2. Consequentialist Proceduralism. - Consequentialist proceduralism, like deontological proceduralism, holds that the participatory process of democracy is valuable quite apart from the substantive quality of the decisions produced by that process. Unlike deontological theorists, however, consequentialist theorists do not believe the value of the process is inherent or logically entailed by some fundamental moral principle. Instead, they contend that the democratic process is valuable because it produces morally valuable effects (but effects having nothing to do with the quality of the legislation the process generates).

Consequentialist proceduralism focuses on the positive influences the very process of participatory government is likely to have on individuals or on society at large. This strain of theory began with the ancient 
Greeks. In his Politics, for example, Aristotle equated the ideal individual with the ideal citizen; the fullest conception of Aristotelian humanity was bound up with participation in politics, and as such required a democratic polity. In a nondemocratic polity there were two kinds of individuals, "ruler and ruled," and each required "different sorts of knowledge" in order to fulfill his role properly. ${ }^{54}$ But in a democracy everyone was a "citizen," one "who shares in the administration of justice and in the holding of office," 55 and thus every individual "should have both sorts of knowledge"-that is, that of the ruler and that of the ruled-"and share in both." 56 Democracy thus encouraged, indeed forced, individuals to broaden their understanding, to attain knowledge "from both points of view." 57 Aristotle also equated the good life with "well-doing," with "the life of action," 58 by which he meant a life connected in some way to political activity. Thus democracy, with its processes of participatory government, was in the Aristotelian view a means of improving the character of the individual and leading him toward the good life.

Rousseau, while an autonomy-based theorist in many respects, also believed in the consequentialist, humanistic benefits of democratic government. He famously saw majority rule as a mechanism by which the majority, faced with a dissenter, could "force him to be free."59 Part of what he meant was that the process of participating in democratic deliberation could teach the individual to abandon her "private will" and adopt a concern for the common good-that the individual could be, in Carole Pateman's analysis, "forcibly' educated through participating in decisionmaking." 60 This is reminiscent of Aristotle's confidence that the democratic citizen would be forced to consider things "from both points of view," that of the private individual and that of the public citizen.

John Stuart Mill, too, often took this sort of consequentialist approach to democracy. For Mill, a "[c]riterion of a [g]ood [f]orm of [g]overnment" was "how far [it] tend[s] to foster in the members of the community the various desirable qualities, ... moral, intellectual, and active."61 The good individual for Mill possessed "industry, integrity, justice, and prudence"; 62 these "active self-helping" qualities were submerged "by the government of one or a few" but were encouraged, even

54. Aristotle, The Politics 103-04 (Ernest Barker trans., Oxford Univ. Press 1946).

55. Id. at 93.

56. Id. at 104 .

57. Id. at 105 .

58. Id. at 287-89.

59. Rousseau, supra note 37 , at 25.

60. Carole Pateman, Participation and Democratic Theory 26 (1970).

61. John Stuart Mill, Considerations on Representative Government (1861), reprinted in John Stuart Mill, Utilitarianism, On Liberty, and Considerations on Representative Government 187, 198, 208 (H.B. Acton ed., J. M. Dent \& Sons 1972) [hereinafter Mill, Representative Government].

62. Id. at 201. 
necessitated, by self-government. ${ }^{63}$ In a system of self-government the individual was required to make choices, and " $[t]$ he mental and moral, like the muscular powers, are improved only by being used" in this way. ${ }^{64}$ As such, Mill's "ideally best Form of Government" was a democratic one, "one in which the whole people participate."65

As in deontological theories, participation thus plays a crucial role in these kinds of consequentialist theories of democracy. It is the very fact of participation that serves to educate and edify the individual, to inculcate the right moral values and a sense of the common good. Thus the participatory processes of democracy are at least as important as its substantive results, objectively advantageous though those results might be. Results are only part of the story; as Mill sneered, the concept of a "good despotism," one that produces good laws, implies "a radical and most pernicious misconception of what good government is." 66

A related form of consequentialist proceduralism defends democracy because it indirectly benefits not just individuals, but society at large. The best-known example of this variety of theory is probably Tocqueville's. ${ }^{67}$ For Tocqueville, the benefits of democracy were realized "in an imperceptible and almost secret way. ... . [I] ts good qualities [were] revealed only in the long run."68 Tocqueville found democracy in America to be inefficient, cumbersome, and shortsighted; administration was "unstable" and politicians were eminently "corruptible."69 But democracy worked nonetheless. Its "true advantages," according to Tocqueville, were its unintended consequences:

Democratic freedom does not carry its undertakings through as perfectly as an intelligent despotism would ... but in the long run it produces more; each thing is less well done, but more things are done. Under its sway it is not especially the things accomplished by the public administration that are great, but rather those things done without its help and beyond its sphere. Deinocracy does not provide a people with the most skillful of governments, but it does that which the most skillful governments often cannot do: it spreads throughout the body social a restless activity, superabundant force, and energy never found

\section{Id. at 231.}

64. John Stuart Mill, On Liberty (1861), reprinted in Mill, supra note 61, at 69, 126.

65. Mill, Representative Government, supra note 61, at 217, 234. Carole Pateman describes the participatory nature of both Rousseau's and Mill's conceptions of democracy in Pateman, supra note 60, at 22-35.

66. Mill, Representative Government, supra note 61 , at 217.

67. My discussion of Tocqueville's theory here follows the much more extensive treatment in Stephen Holmes, Tocqueville and Democracy, in The Idea of Democracy 23 (David Copp et al. eds., 1993).

68. Tocqueville, supra note 29 , at 231.

69. Id. at 196-230; see also Holmes, supra note 67, at 26-29 (canvassing Tocqueville's identification of defects inherent to American democracy). 
elsewhere, which, however little favored by circumstance, can do wonders. ${ }^{70}$

Democracy for Tocqueville was a good thing, that is, because it energized "the body social," producing in turn a prosperity and abundance impossible in nondemocratic regimes. And this energy came from the very process of participatory politics. As Stephen Holmes summarizes Tocqueville's views, "[b]y electing their rulers and indirectly making their laws, democratic citizens produce mediocre governance and shoddy legislation. But they sinultaneously transform themselves into more energetic and active individuals. . ."71 The zeal for political activity generated in the individual by democratic government, the enthusiasm for shaping the conditions of one's life through politics, transferred readily to the private realm, generating vigorous activity and enlighteninent. "It is ... not the elected magistrate who makes ... democracy prosper, but the fact that the magistrates are elected."72

There are other, similar consequentialist justifications of democracy. Deinocracy has been thought, for instance, to protect against the rise of tyranny by encouraging citizens' awareness of public affairs ${ }^{73}$ and to avoid violent factionalism by allowing citizens to "blow off steam" through electoral participation. ${ }^{74}$ Any theory that, like these, values participatory government as a means of producing good effects aside from the substantive legislation it generates is a consequentialist theory as I conceive them here. Like deontological proceduralists, consequentialists favor government through participation over rule by fiat, although they do so for somewhat less obvious reasons. They care little about the quality of the legislation produced by democracy; indeed, with Tocqueville, they might believe democracy to be particularly ineffective in this regard. But they find it valuable nonetheless.

\section{B. Functionalism: Legitimacy Through Results}

Democracy means government by discussion ....

\section{Clement Attlee ${ }^{75}$}

70. Tocqueville, supra note 29 , at 244 .

71. Holmes, supra note 67 , at 34 .

72. Tocqueville, supra note 29 , at 512 . Another, somewhat less important beneficial side effect of participatory government was, according to Tocqueville, that it encouraged respect for and obedience to the law. See id. at 240-41.

73. See David Copp, Could Political Truth Be a Hazard for Democracy?, in The Idea of Democracy, supra note 67, at 101, 112; Holmes, supra note 67, at 32-33. effect).

74. See Holmes, supra note 67 , at 31-32 (describing Tocqueville's views to this

75. Clement Attlee, Speech at Oxford (June 14, 1957), quoted in Lord Attlee on Art of Being Prime Minister, Times (London), June 15, 1957, at 4. My use of this quotation is somewhat disingenuous: Attlee's full statement was "Democracy means government by discussion, but it is only effective if you can stop people talking." Id. 
Wholly apart from any proceduralist arguments, the legitimacy of democratic government also might be traced to the quality of the substantive decisions which that form of government is thought to produce. Democratic government can be valued because it generates legislation through a process of reasoned deliberation and negotiation among a wide variety of viewpoints and interests, thus increasing the likelihood that its laws truly will serve the common good in comparison with, say, laws generated by a single homogeneous elite. This kind of justification of democracy can be found in strong form in, among other places, the thought of our own Founders, particularly Madison and Jefferson; the writings of our eclectic friend John Stuart Mill and of John Dewey; and the descriptions of "deliberative democracy" espoused in its most articulate form by the contemporary constitutional scholar Cass Sunstein.

The basic reasons why democracy is thought to function well as substantive government, to produce decisions of high quality, are intertwined with and dependent upon one another. They are, respectively, that democracy allocates decisionmaking power to those most interested in the decisions; that it allows a diversity of interests to assert themselves in government; that it permits the participation of the most talented decisionmakers in government; and that it produces decisions through a process of reasoned deliberation. As we shall see, each of these reasons, like proceduralist theories, relies upon the participatory nature of democracy.

1. Allocation of Decisionmaking Power. - The functionalist argument from the proper allocation of decisionmaking power begins with the premise that the best decisionmakers are those individuals whose interests will be affected by the decisions. As John Stuart Mill put it, the "proposition-that each is the only safe guardian of his own rights and interests-is one of those elementary maxims of prudence, which every person ... implicitly acts upon."76 John Dewey similarly described the democratic ideal as in part "the conception of a social harmony of interests in which the achievement by each individual of his own freedom should contribute to a like perfecting of the powers of all,"77 and proclaimed that "[p]ersonal responsibility [] [and] individual initiation ... a are the notes of democracy."78 "The man who wears the shoe," wrote Dewey, "knows best that it pinches and where it pinches."79

From this premise, that the individual is the best "guardian of his own rights and interests," springs the idea of participatory government.

76. Mill, Representative Government, supra note 61, at 224.

77. John Dewey, Intelligence and Morals, in Ethics (1908), reprinted in John Dewey: The Political Writings 66, 69 (Debra Morris \& Ian Shapiro eds., Hackett Publ'g Co. 1993) [hereinafter Dewey, Writings].

78. John Dewey, The Ethics of Democracy, in The Early Works (1967), reprinted in Dewey, Writings, supra note 77 , at 59, 61.

79. John Dewey, The Public and Its Problems, reprinted in 2 John Dewey: The Later Works 1925-1953, at 235, 364 (Jo Ann Boydston ed., S. Ill. Univ. Press 1984) (1927) [hereinafter Dewey, The Public]. 
If each individual knows best how to protect her interests, then the way to ensure that government decisions will protect the interests of as many individuals as possible is to involve those individuals in the making of those decisions. Any other system of government is likely to go wrong because it necessarily involves decisionmaking by one person or group of people about the interests of others, and, in Mill's words, "no intention, however sincere, of protecting the interests of others can make it safe or salutary to tie up their own hands." 80 But participatory government over individuals is government "by their own hands";81 as such, it is government by those best able to govern. It is, on this view, simply a matter of government by the most qualified.

Herbert Spencer neatly articulated the allocation of power argument in favor of democracy:

The rationale of the matter is simple enough. Manifestly, on the average of cases, a man will protect his own interests more solicitously than others will protect them for him. Manifestly, where regulations have to be made affecting the interests of several men, they are most likely to be equitably made when all those concerned are present, and have equal shares in the making of them.... The general principle is that the welfare of all will be most secure when each looks after his own welfare; and the principle is carried out as directly as the circumstances permit. 82

On this view, democracy improves the decisionmaking competence of government by constituting it so that it operates through the mechanism of "each [individual] look [ing] after his own welfare." Participatory decisionmaking shifts power to those best equipped to use it: the individuals who will be affected by the decisions.

Note the functionalist emphasis of this argument. The point is not simply to leave individuals as much as possible to their own devices; it is to produce the best substantive governance for all, to ensure "that the welfare of all will be most secure,"83 that the common good will be served. For Mill this meant "Progress"; 84 for Dewey it meant an ongoing process of experimentation producing successively greater quantities of social harmony ${ }^{85}$ Note also the distinction between the functionalist argument from allocation of decisionmaking power and the consequentialist ver-

80. Mill, Representative Government, supra note 61 , at 226.

81. Id.

82. Herbert Spencer, Representative Government-What Is It Good For?, in The Man Versus the State 331, 375 (LibertyClassics 1981) (1892).

83. Id.

84. See Mill, Representative Government, supra note 61, at 200-06.

85. See John Dewey, Creative Democracy: The Task Before Us, reprinted in Dewey, Writings, supra note 77, at 240 [hereinafter Dewey, Creative Democracy]; Dewey, supra note 77, at 66-76; John Dewey, Liberalism and Social Action, reprinted in 11 John Dewey: The Later Works 1925-1953, at 1, 41-65 (Jo Ann Boydston ed., S. Ill. Univ. Press 1987) (1935) [hereinafter Dewey, Liberalism]; John Dewey, The Economic Basis of the New Society, reprinted in Dewey, Writings, supra note 77, at 169; Dewey, The Public, supra note 79 , at $351-72$. 
sions of proceduralism we examined above: Where those proceduralist theories focused upon the indirect, nonpolitical benefits of the very process of participatory government-its development of individual character, its invigoration of society-the argument from allocation of power focuses on the substantive legislative benefits likely to arise from democracy, on the quality of the political decisionmaking democracy is suited to produce.

2. Assertion of a Diversity of Interests. - Closely related to the argument from allocation of power is the argument from diversity of interests. In a democracy, the argument goes, better government decisions will be produced than in a system of rule by the few because, simply, more voices will be heard in the decisionmaking process. The element of broad participation in decisionmaking ensures that a variety of interests and viewpoints will be represented. This in turn increases the odds that the resulting decisions will truly serve the common good-by avoiding the effects of shortsightedness, serving more than merely the interests of narrow factions of society, appreciating and addressing a variety of interlocking issues, and so on.

The argument was famously expressed by Madison in The Federalist No. 10. Arguing in favor of a large, diverse democracy, Madison asserted:

The smaller the society, the fewer probably will be the distinct parties and interests composing it; the fewer the distinct parties and interests, the more frequently will a majority be found of the same party; and the smaller the number of individuals composing a majority, and the smaller the compass within which they are placed, the more easily will they concert and execute their plans of oppression. Extend the sphere and you take in a greater variety of parties and interests; you make it less probable that a majority of the whole will have a common motive to invade the rights of other citizens; or if such a common motive exists, it will be more difficult for all who feel it to discover their own strength and to act in unison with each other. ${ }^{86}$

Here Madison emphasized the checking function of diversity: The participation in government of "distinct parties and interests" ensured that government decisions would serve the common good rather than any narrow "plans of oppression" devised by self-interested factions. Mill saw somewhat more positive advantages to diversity. For him, the point was less to avoid the dominance of factions than to allow every voice to be heard and to contribute to the debate about the common good:

I know not how a representative assembly can more usefully employ itself than in talk, when the subject of talk is the great public interests of the country, and every sentence of it represents the opinion either of some important body of persons in the nation, or of an individual in whom some such body have reposed their confidence. A place where every interest and shade

86. The Federalist No. 10, at 127 (James Madison) (Isaac Kramnick ed., 1987). 
of opinion in the country can have its cause even passionately pleaded . . . is in itself, if it answered no other purpose, one of the most important political institutions that can exist anywhere, and one of the foremost benefits of free government.87

Similarly, Dewey saw democracy as a process of identifying "more numerous and more varied points of shared common interest"88 - as contributing to a better understanding of the common interest through the participation of a variety of individual interests. In a democracy, experts might make the particular decisions, but "the masses ... have the chance to inform the experts as to their needs;" 89 the political processes of participatory government "involve a consultation and discussion which uncover social needs and troubles."90

The functionalist argument from diversity of interests thus takes the argument from allocation of power one step further. It recognizes not only that the functionally best government is self-government-because the interested party knows best what her interests are and how to serve them-but also that overarching social policy, because it must address a variety of concerns, is best made by taking into account a variety of individual interests. The argument values participatory government not only because it confers decisionmaking power on those affected by decisions, but because it confers power on everyone affected by decisions.

3. Participation of Talented Decisionmakers. - A third functionalist argument in favor of democracy is that it permits the most able and talented members of society to participate in making social decisions. Part of this argument is simply the argument from diversity rom a different angle: In allowing the participation in government, through suffrage, of the entire spectrum of individuals affected by government, democracy also allows those individuals possessing special capacities for policymaking to influence the decisional process. Thus Mill extolled democracy as

an organisation of some part of the good qualities existing in the individual members of the community for the conduct of its collective affairs. A representative constitution is a means of bringing ... the individual intellect and virtue of its wisest members, more directly to bear upon the government, and investing them with greater influence in it, than they would in general have under any other mode of organisation. ${ }^{91}$

Indeed, Mill favored improving democracy by allowing the votes of "wiser and better men" to count for more than the votes of others, with occupation and education serving as the tests of wisdom and virtue. ${ }^{92}$

87. Mill, Representative Government, supra note 61 , at 259.

88. John Dewey, The Democratic Conception in Education, reprinted in Dewey, Writings, supra note 77 , at $110,110$.

89. Dewey, supra note 79 , at 365 .

90. Id. at 364.

91. Mill, Representative Government, supra note 61, at 209-10.

92. Id. at 306-14. 
Dewey similarly viewed democracy as a means of allowing the particular talents of individuals to influence government, although he did not endorse Mill's suggestion of plural voting. For Dewey, democracy was "a claim that every human being as an individual may be the best for some particular purpose and hence be the most fitted to rule, to lead, in that specific respect." 93 As such, it stood in stark contrast to aristocratic government, which "always limits the range of men who are regarded as participating in the state." 94 In this sense, participatory government was effective not only because it incorporated a wide variety of views in the decisionmaking process, but because it incorporated a wide variety of talents as well.

This aspect of the argument from participation of talent thus focuses on the base of the decisionmaking pyramid, on the incorporation into government of individual talent through the process of universal suffrage. A second aspect of the argument focuses on the top of the pyramid, on the individuals actually elected to public office. It holds that democracy is likely to produce better decisions because it allows its statesmen and policymakers to be selected on the basis of merit rather than birth, wealth, or some other arbitrary criterion. Thomas Jefferson gave characteristically eloquent voice to this position in a letter to his friend and rival John Adams:

I agree with you that there is a natural aristocracy among men. The grounds of this are virtue and talents. Formerly bodily powers gave place among the aristoi. ... There is also an artificial aristocracy founded on wealth and birth, without either virtue or talents .... The natural aristocracy I consider as the most precious gift of nature for the instruction, the trusts, and government of society. . . . May we not even say that that form of government is the best which provides the most effectually for a pure selection of these natural aristoi into the offices of government? The artificial aristocracy is a mischievous ingredient in government, and provision should be made to prevent it's [sic] ascendency. ... .

$I$ think the best remedy is exactly that provided by all our constitutions, to leave to the citizens the free election and separation of the aristoi from the pseudo-aristoi, of the wheat from the chaff. In general they will elect the real good and wise. ${ }^{95}$

Mill similarly saw democracy as a means of promoting meritocratic government but, in a typically reformist mood, thought that a system of proportional representation was necessary to ensure it. ${ }^{96}$

93. John Dewey, Individuality, Equality and Superiority (1992), reprinted in Dewey, Writings, supra note 77 , at $77,77-78$.

94. John Dewey, The Ethics of Democracy, reprinted in Dewey, Writings, supra note 77 , at 59,61 .

95. Letter from Thomas Jefferson to John Adams (Oct. 28, 1813), in Jefferson, Writings, supra note 12, at 1304, 1305-06.

96. See Mill, Representative Government, supra note 61, at 277-93. 
The functionalist argument from participation of talent thus values participatory government for two related reasons. It holds that broad participation through suffrage ensures the contribution of individual talent to the pursuit of the common good. And it posits that participatory suffrage promotes the selection of officials based upon merit and not upon wealth, birth, or other criteria that are irrelevant to good lawmaking.

4. Decisionmaking Through Reasoned Deliberation. - A final functionalist argument in favor of democratic government, one that relies to a great extent upon the previous three, is that it forces government decisions ultimately to be made not upon the basis of individual interests or "naked preferences" but through a process of reasoned deliberation, of interplay among a variety of ideas and viewpoints and eventual agreement on the best course of action. This argument from deliberation incorporates the ideas of allocation of power to interested individuals, diversity of interests, and participation of talented decisionmakers into a theory about the nature of both electoral and representative decisionmaking. The theory holds that antithesis ultimately produces a better consensus, that the clash of differing, even opposing interests and ideas in the process of decisionmaking, because it forces proponents of each position to present reasoned arguments in favor of it, creates decisions that are better for having been subjected to this trial by fire. Thus better representatives are elected when the election is hotly contested, and better laws are enacted following vigorous parliamentary debate.

Cass Sunstein is perhaps the most influential contemporary exponent of this theory of deliberative democracy. He states the argument this way:

[A] large point of the system [of representative democracy] is to ensure discussion and debate among people who are genuinely different in their perspectives and position, in the interest of creating a process through which reflection will encourage the emergence of general truths. A distinctive feature of American republicanism is extraordinary hospitality toward disagreement and heterogeneity, rather than fear of it. The framers believed that a diversity of opinion would be a creative and productive force. ...

... Public deliberation may reveal the truth or falsity of factual claims about the state of the world or about the likely effects of policy proposals. Through confrontation among people who disagree, errors of fact may be revealed as such. ${ }^{97}$

97. Cass R. Sunstein, Democracy and the Problem of Free Speech 241-43 (1993) (footnote omitted) [hereinafter Sunstein, Democracy]. For a similar exegesis of Professor Sunstein's views on deliberative democracy, see Cass R. Sunstein, The Partial Constitution 17-39 (1993) [hereinafter Sunstein, Constitution]. 
Sunstein's version of deliberative democracy draws upon the thought of the American Founders, who similarly believed in the power of discussion and deliberation in a representative democracy, ${ }^{98}$ and of John Dewey, ${ }^{99}$ who in his later writings strongly emphasized democracy's deliberative component. Dewey-who, as we have already seen, was fond of broad, quotable aphorisms about what "democracy is"-saw democracy as in part the method of "persuasion through public discussion carried on not only in legislative halls but in the press, private conversations and public assemblies." 100 It was "[t]he substitution of ballots for bullets, of the right to vote for the lash ... [ [of] the method of discussion for the method of coercion."101 The "democratic faith" was, for Dewey, a "faith in the possibility of conducting disputes, controversies and conflicts as cooperative undertakings in which both parties learn by giving the other a chance to express itself." 102 The process of deliberation had to be more than merely a clash of competing viewpoints; it had to be characterized by reasons offered by either side, by "science" and "intelligence."103 But when these conditions were present, deliberation produced better decisions not only from the legislature, but from the electorate itself: "[T]he act of voting is in a democratic regime a culmination of a continued process of open and public communication in which prejudices have the opportunity to erase each other; ... [and] continued interchange of facts and ideas exposes what is unsound and discloses what may make for human well-being."104

The functionalist argument from deliberation thus relies upon the participation of a diversity of affected interests to produce government decisions that account for and synthesize those interests through a method of reasoned discussion, of eliminating prejudice and blind selfinterest, exposing error, and producing consensus. It favors participatory government over government by fiat because, simply, the former is more likely to get it right. ${ }^{105}$

98. See Sunstein, Constitution, supra note 97, at 20-24; Sunstein, Democracy, supra note 97, at 242 (citing The Federalist No. 10 (James Madison), No. 81 (Alexander Hamilton)).

99. See, e.g., Sunstein, Democracy, supra note 97 , at 248 \& n.17.

100. John Dewey, Democracy and Human Nature (1939), reprinted in Dewey, Writings, supra note 77 , at $219,228$.

101. Id.

102. Dewey, Creative Democracy, supra note 85, at 243.

103. Dewey, Liberalism, supra note 85 , at 50-51.

104. John Dewey, John Dewey Responds (1950), reprinted in Dewey, Writings, supra note 77 , at $246,248$.

105. Of course, we may have reason to suspect that visions of democracy as characteristically deliberative might on occasion be overly optimistic. Public choice theory, for example, has called into question the model of democratic politics as a process of reasoned deliberation and compromise among a variety of equally motivated, equally powerful interests. See, e.g., Russell Hardin, Public Choice Versus Democracy, in The Idea of Democracy, supra note 67, at 157 (summarizing public choice critique of democracy); cf. Thomas Christiano, Social Choice and Democracy, in The Idea of Democracy, supra 


\section{Participation and Representation}

[M]anifestly, where those concerned are so numerous and so dispersed, that it is physically impossible for them all to take part in the framing of ... regulations, the next best thing is for citizens in each locality to appoint one of their number to speak for them, to care for their claims, to be their representative.

Herbert Spencer ${ }^{106}$

[I]t may well happen that the public voice, pronounced by the representatives of the people, will be more consonant to the public good than if pronounced by the people themselves, convened for the purpose.

The Federalist No. 10 (James Madison) $^{107}$

If it be asked, what is to restrain the House of Representatives from making legal discrimmations in favor of themselves and a particular class of society? I answer: the genius of the whole system ....

\section{The Federalist No. 57 (James Madison) 108}

We have seen, then, how both proceduralist and functionalist theories of democracy value the individual's participation in government. Proceduralists value participation for its own sake; they hold that the ability of the governed to participate in government decisionmaking gives expression to fundamental values or serves important ends. In contrast, functionalists value participation because they believe that a participatory process of decisionmaking generates decisions that are substantively better than those that would be generated by a process of decisionmaking by fiat.

But, referenda and the occasional New England town meeting aside, we do not have a system of direct public participation in lawmaking in place in the United States. Instead we have a system of representative government. In our system, most citizens "participate" in government only at the polls, by voting for representatives who then convene and make the laws. How does this square with the emphasis placed by both proceduralist and functionalist strains of democratic theory upon participatory government?

That question, as the first two quotations opening this section suggest, has been answered in two different ways. To an extent, how it is answered depends upon whether one's justification of democracy is

note 67 , at 173 (defending democracy against public choice critique). But the point of the argument from reasoned deliberation is not that democracy always functions perfectly (or even particularly well) in this regard; it is, rather, that democracy typically functions better in this regard than other forms of government, like dictatorship or oligarchy.

106. Spencer, supra note 82 , at 375 .

107. The Federalist No. 10, at 126 (James Madison) (Isaac Kramnick ed., 1987).

108. The Federalist No. 57, at 345 (James Madison) (Isaac Kramnick ed., 1987). 
proceduralist or functionalist, but this need not be so. Both approaches justify the institution of political representation as a solution to a problem; the approaches differ in their identification of the problem.

By the first approach, representation is necessary to solve the simple problem of the unwieldiness, in Spencer's terms, the "physical[ ] impossib [ility]," 109 of rule by direct popular democracy in a large and populous state. Because it is a practical impossibility for every citizen of the United States to vote on every legislative issue, the next-best procedure is for every citizen to vote for a representative, with the winning representatives voting on every legislative issue. The principle of participation is implemented by proxy, "as directly as the circumstances permit."110 The values attached to or served by participation are, as we shall see in the next section, preserved by the fact that everyone may participate in deciding who will represent them and in replacing those people if they do not represent well.

By the second approach, representation is necessary to solve the problems of lawmaking quality that would arise from direct popular democracy, even assuming that form of government to be practically feasible. Madison's argument in The Federalist No. 10 exemplifies this position. In Madison's view, direct democracy would be susceptible to the "mischiefs of faction"111 and the ebb and flow of momentary passions. "[S] own in the nature of man" was "[a] zeal for different opinions" that "divided mankind into parties, inflamed them with mutual animosity, and rendered them much more disposed to vex and oppress each other than to co-operate for the common good." 112 The conduct of government through representatives partially solved these problems by requiring that popular opinions flow through the temperate filter of calm, experienced intermediaries before becoming law. As Madison wrote:

The effect of the ... difference [between direct democracy and representative government] is ... to refine and enlarge the public views by passing them through the medium of a chosen body of citizens, whose wisdom may best discern the true interest of their country and whose patriotism and love of justice will be least likely to sacrifice it to temporary or partial considerations. ${ }^{113}$

In this second view, representative government also solves another problem inherent in a direct democracy: the problem of amateurism. "No man," wrote Madison in The Federalist No. 53, "can be a competent legislator who does not add to an upright intention and a sound judgment a certain degree of knowledge of the subjects on which he is to

109. Spencer, supra note 82 , at 375 .

110. Id.

111. The Federalist No. 10, at 126 (James Madison) (Isaac Kramnick ed., 1987).

112. Id. at 124.

113. Id. at 126. 
legislate."114 Everyday citizens, of course, have such knowledge with respect to their own particular spheres of interest, but with respect to other subjects they are lost. And everyday citizens have everyday lives; they cannot be bothered to become experts on every subject of potential legislation. An elected body of representatives, serving for a reasonable amount of time before standing for reelection, solves these problems: Each legislator has the time and motive to become reasonably acquainted with every subject upon which legislation must be passed.

The first justification of representation discussed above fits best with a proceduralist rather than a functionalist view of democracy, because it considers actual participation in legislation to be the ideal and representation as a necessary second-best alternative. A functionalist could, of course, also hold such a view, although the second type of justification, focusing as it does on the quality of substantive legislation produced by the different forms of democracy, accords more with functionalism. The key point is simply that adherents of both types of democratic theory, proceduralist and functionalist, can accept constructive participation in legislation through representation as a legitimate form of democratic selfgovernment, and as an adequate (or even superior) substitute for direct participation itself. Both types of theory demand personal, individual participation only in the selection of the lawmakers, not in the actual authorship of the laws.

It is one thing, however, to recognize the necessity of representative government; it is another to make sure that it works in a democratic way. The mechanisms by which we do so in our system of representative democracy are generally so well known as to require little comment; they are the stuff of a high school civics class. The people, we know, can choose their representatives and can replace them periodically with others if the quality of representation is deemed inadequate. They have the power of electoral coercion, and this power is a strong incentive indeed to legislative responsibility. This is why, in Madison's understated phrase, electing our representatives is "the characteristic policy of republican government."115

But in addition to simple electoral coercion, there is a second, related element of our representative system that is often overlooked. Through the power of the vote, the people in a representative democracy have the ability to promote interest representation: They can select as representatives people who, because they have certain key similarities with their constituents, will be independently likely to act in the constituents' interests. Interest representation is important in its own right as a mechanism of representative government, from both a proceduralist and a functionalist perspective. 
Let us look briefly at these twin mechanisms, electoral coercion and interest representation. In doing so, we will examine representative government first from a proceduralist and then from a functionalist perspective. The point will be to demonstrate how representative government operates to meet the concerns of both proceduralist and functionalist theorists of democracy.

\section{Electoral Coercion}

a. Proceduralist Legitimacy. - From a proceduralist standpoint, legitimacy in a system of representative democracy like that in the United States is achieved in part because citizens have the ability freely to choose their legislators and to replace them periodically by election. This mechanism of electoral control provides an incentive for legislators to act in accordance with citizens' wishes, that is, to enact the sorts of laws that citizens want enacted:

[Representatives] will be compelled to anticipate the moment when their power is to cease, when their exercise of it is to be reviewed, and when they must descend to the level from which they were raised; there forever to remain unless a faithful discharge of their trust shall have established their title to a renewal of it.116

The electoral mechanism also allows the people to repair the effects of inadequate representation by replacing legislators who fail to legislate well with new legislators who then can enact better laws. (This latter function is really one of electoral remediation, not electoral coercion, but it is tightly bound up with the coercive premise of elections.)

Of course, it is a matter of continuing controversy whether legislative representatives should be guided primarily by the "wishes" or "preferences" of their constituents, by the "best interests" of their constituents despite their expressed preferences, by the good of the state or the nation as a whole, by some combination of these standards, or indeed by some different standard or standards altogether. ${ }^{117}$ But regardless of how elected representatives ideally should act on behalf of their constituents, the democratic system of electoral control ensures that the people have the ability to replace legislators whom they see to be acting improperly (by whatever standard the constituents choose to apply). This fact of electoral control means that the laws produced by the elected legislators can in a real sense be said to have been created through a system of citizen participation.

b. Functionalist Legitimacy. - Electoral coercion is important on a functionalist view as well. Like proceduralism, functionalism relies upon a close correspondence between the actions of the legislative representative and the viewpoints and interests of her constituents. Without such a

116. Id. at $344-45$.

117. For an indispensible survey of various views on the proper role of the representative in a democracy, see Hanna Fenichel Pitkin, The Concept of Representation 144-240 (1967). 
close correspondence, the functional values served by citizen participation in government cannot be served; the diversity of viewpoints and interests in the body politic at large will not accurately be translated into legislation unless each legislator accurately represents the views and interests of her constituency in the legislative debate. So, just as electoral coercion preserves the procedural values of participation by giving each citizen indirect influence over the content of the laws, it preserves the functional values of participation by conducting the interests and ideas of the people "through the medium"118 of their representatives.

\section{Interest Representation}

a. Proceduralist Legitimacy. - Besides bare electoral control, there is another important, related aspect of representative democracy that allows the electorate to control or consent to legislation (and thus is legitimate according to proceduralist theories). We tend to expect our legislative representatives to have something in common with us-to share some of our central characteristics and thus, presumably, some of our interests. ${ }^{119}$ That is, we expect our representatives to serve us conscientiously not only because they desire reelection but also because they are like us in some fundamental ways and because, thanks to this fundamental likeness, their interests and ours to some important degree coincide.

Recognition of this fact of political life, this affinity for representatives that remind us of ourselves, partly explains the practice of so-called "racial gerrymandering" of electoral districts to allow ethnically or racially homogeneous communities the opportunity to send "one of their own" to the state capitol or to Washington. It also largely underlies recent proposals by theorists like Lani Guinier to move beyond "black single-member districts" and establish a system of "proportionate interest representation" that would ensure the presence in government of a proportionately "fair" number of minority representatives and thus guarantee that the true interests of minority groups are not overlooked in legislation. ${ }^{120}$ Indeed, the desire for a bond of interest between the representative and her constituency is displayed every time we vote for a candidate because her stand "on the issues" is similar to ours. If we viewed elections only as tools of incentive and coercion, we would care little whom we elected. The fact that we prefer one candidate to the next presupposes a concern for kinship of interests.

In other words, part of the point of democratically electing legislative representatives is not simply to provide an incentive for them to act in ways we find satisfactory and to replace them if they fail to do so, but also to allow people to elect representatives likely to look out for their constituents' interests even aside from the coercive force of the polls. Incorpo-

118. The Federalist No. 10, at 126 (James Madison) (Isaac Kramnick ed., 1987).

119. I mean "interests" in the sense not of avocations or enthusiasms but of desires, preferences, benefits, or advantages. See Pitkin, supra note 117, at 60-91, 168-89.

120. See Lani Guinier, The Triumph of Tokenism: The Voting Rights Act and the Theory of Black Electoral Success, 89 Mich. L. Rev. 1077, 1134-53 (1991). 
rated within a proceduralist theory of democracy, then, is the idea of interest representation - of legislators who truly represent our interests, not merely because they desire reelection, but because our interests are their interests, too. The idea of interest representation reflects a faith not only in the power of electoral coercion, but also in the power of electoral affinity.

Note the distinction between interest representation in the sense in which I mean it here and the broader kind of interest representation that is promoted by a bare mechanism of electoral coercion. Electoral coercion operates to encourage representatives to "represent" the "interests" of their constituents by threatening the representatives with unemployment if they do not do so. As such, electoral coercion works precisely because the interests of the representative are unique; they are her interests qua representative, that is, her interests in getting reelected. By contrast, the kind of interest representation I describe here encourages representatives to act in the interests of their constituents precisely because the representative's interests are not unique. Interest representation operates because the representative's interests are the same as the interests of a majority of her constituents; they are her interests qua private citizen. Thus what I call (following a long tradition) interest representation might better be thought of as "representation through interest congruity." Its unique element is not the representation of the constituents' interests, which also is promoted by bare electoral coercion. Its unique element, rather, is the harmony it embodies between the constituents' interests and the representative's own interests as private citizen.

Although interest representation and electoral coercion are distinct in this way, however, they are far from incompatible. The goal of both devices is the same: to ensure that representatives act according to the interests of a majority of their constituents. Electoral coercion promotes this goal by giving legislatures unique incentives to act in this way, while interest representation promotes this goal by selecting legislators with the same incentives to act in this way that their constituents have. And both mechanisms can be implemented simultaneously through the electoral process. In voting for a representative, we are telling her to act in our interests under threat of losing her job; we also are selecting the representative we believe is most likely to represent our interests even absent this threat. As such, interest representation serves in a representative democracy as a complement, and perhaps as a supplement, to electoral coercion.

The idea of interest representation recalls the theory of "virtual representation" most closely associated with Edınund Burke. Burke's theory held that constituencies could legitimately be represented by legislators possessing "a communion of interests and a sympathy in feelings and desires" with their constituents even if the representatives were not actu- 
ally elected by the people said to be represented. ${ }^{121}$ For Burke, virtual representation was

in many cases even better than the actual. It possesses most of its advantages, and is free from many of its inconveniences; it corrects the irregularities in the literal representation, when the shifting current of human affairs or the acting of public interests in different ways carry it obliquely from its first line of direction. The people may err in their choice; but common interest and common sentiment are rarely mistaken. ${ }^{122}$

The American Framers shared Burke's notion of interest representation, although they appreciated that interest representation is better realized when representatives are more than virtual-when they are in fact chosen by those they may be said to represent, whom we presume to be the best judges of just whose interests coincide with their own. ${ }^{123}$ "Different interests," wrote Madison, "necessarily exist in different classes of citizens," 124 and "[i]t is a sound and important principle that the representative ought to be acquainted with the interests and circumstances of his constituents." 125 And how better to become "acquainted with" one's constituents' interests and circumstances than to share those interests and circumstances oneself? Thus the fact that the representatives

can make no law which will not have its full operation on themselves and their friends, as well as the great mass of society ... creates between [the representative and the constituent] that communion of interests and sympathy of sentiments of which few governments have furnished examples; but without which every government degenerates into tyranny. ${ }^{126}$

Today we may not share Madison's faith that "interests" are so easily definable in the abstract or so readily equatable with "different classes of citizens." But we retain his insight, and Burke's, that when representatives share with their constituents "a communion of interests and a sympathy in feelings and desires,"127 those representatives are more likely than aloof, disconnected agents to recognize and respond to the true needs of the constituency. This indeed is part and parcel of the

121. Letter from Edmund Burke to Sir Hercules Langrishe, M.P. (Jan. 3, 1792), excerpted in Burke's Politics 477, 494 (Ross J.S. Hoffman \& Paul Levack eds., 1959).

122. Id. at 494-95.

123. Indeed, even Burke recognized that "virtual representation cannot have a long or sure existence if it has not a substratum in the actual. The memher must have some relation to the constituent." Id. at 495.

124. The Federalist No. 51, at 321 (James Madison) (Isaac Kramnick ed., 1987).

125. The Federalist No. 56, at 339 (James Madison) (Isaac Kramnick ed., 1987).

126. The Federalist No. 57, at 345 (James Madison) (Isaac Kramnick ed., 1987).

127. Letter from Edmund Burke to Sir Hercules Langrishe, supra note 121, at 494 . Burke's language here seems lifted almost verbatim from The Federalist No. 57, in which Madison claimed that the members of the House of Representatives would share with their constituents a "communion of interests and sympathy of sentiments." The Federalist No. 57, at 345 (James Madison) (Isaac Kramnick ed., 1987). 
proceduralist view of representative legislation and its corresponding faith in the legitimacy of that institution. 128

b. Functionalist Legitimacy. - A crucial difference between proceduralist and functionalist theories of democracy is that functionalist theories require the legislator at critical moments to exercise her own independent judgment, at least partially unfettered by the expressed wishes of her constituents. This is necessary to actuate the "deliberation" component of deliberative democracy; legislators strictly bound by the wishes of their constituents cannot engage in the process of negotiation, compromise, and persuasion that is required to produce reasoned legislation. In the words of Roger Sherman, arguing in the first Congress against incorporation in the Bill of Rights of a "right to instruct" representatives:

I think, when the people have chosen a representative, it is his duty to meet others from the different parts of the Union, and consult, and agree with them to such acts as are for the general benefit of the whole community. If they were to be guided by instructions, there would be no use in deliberation. ${ }^{129}$

Similarly, Burke told his own constituents:

Your representative owes you, not his industry only, but his judgment; and he betrays, instead of serving you, if he sacrifices it to your opinion.

... If government were a matter of will upon any side, yours, without question, ought to be superior. But government and legislation are matters of reason and judgment, and not of inclination; and what sort of reason is that in which the determination precedes the discussion ... ? ${ }^{130}$

Functionalist theories of democracy, then, require more of the legislator than mere obedience to the whims of her constituents. Functionalist theories require that a legislator, while representing those distinct interests and viewpoints that comprise the particular contribution of her constituency to the broader debate, at the same time enter that debate with an open mind and a willingness to exercise her own unencumbered judgment. In essence, functionalist theories require the legislator to act not as her constituents have told her to act, but as her constituents would act if presented with all of the information and opposing arguments available to the legislator. ${ }^{131}$

128. As Steven Winter has written, "we ordinarily expect those who share our interests and our trust-whether intimate, professional, or political-to speak up for us. . . The political premise of our democracy is that it is representative in character." Steven L. Winter, The Metaphor of Standing and the Problem of Self-Governance, 40 Stan. L. Rev. 1371, 1479 (1988).

129. 1 Annals of Cong. 735 (Joseph Gales ed., 1834).

130. Edmund Burke, Speech to the Electors of Bristol (Oct. 13, 1774), excerpted in Burke's Politics, supra note 121 , at $114,115$.

131. Consider the confidence of a New York state legislator that "had the five thousand people who had written me been in the possession of the knowledge which was 
This delicate balance between strict agency and independent judgment takes us back again to the idea of interest representation, of the embodiment in the legislator herself of the core interests and ideals of her constituents. The legislator concerned only with reelection might cabin her judgment within the strict boundaries of the expressed will of her constituency; she might forego any significant exercise of discretion and thereby defeat the very purpose of democratic deliberation. Conversely, the legislator indifferent to her fate at the polls might move too far in the other direction, pursuing policies that are utterly divorced from the preferences and interests of those she ostensibly represents. But the legislator who is similarly situated to her constituents, who shares a body of common interests with them, can walk the line between responsiveness and independence. She is unlikely to stray too far from their preferences and interests because they are hers as well, and at the same time she can bring those preferences and interests to bear in making independent judgments based on information and arguments unavailable to her constituents. To the functionalist defender of democracy, the interest representative thus is close to the ideal legislator. She brings to the table both a commitment to the distinct interests of her constituency and an openness to persuasion, reason, and compromise.

This concept of participatory legitimacy through interest representation is about to become quite important for my arguments in this Article. As the next Part demonstrates, the process of adjudication-typically thought to be the antithesis of decisionmaking by democratic representation-can, under certain circumstances, claim a significant degree of participatory legitimacy in precisely this way.

\section{The Legitimacy of Adjudicative Lawmaking: Adjudication As REPRESENTATION}

Reasoning by example in the law is a key to many things. It indicates in part the hold which the law process has over the litigants. They have participated in the lawmaking. They are bound by something they helped to make.

\section{Edward Levi ${ }^{132}$}

Whether we view democratic legislation from a proceduralist or from a functionalist angle, we find it to be legitimate because it is legislation by participation rather than by fiat. With democratic parliamentary lawmaking as our baseline, then, we tend to characterize adjudicative lawmaking as nonparticipatory and thus nondemocratic; we tend therefore to look elsewhere (to necessity, for instance) to justify it. The result is an uneasy tension between institutions like common lawmaking, judicial interpreta-

132. Levi, supra note 11 , at 4. 
tion of statutes, and judicial review on the one hand, and our ideals of democracy on the other.

In approaching adjudicative lawmaking in this way, we ignore two of its fundamental features-features that, in conjunction, clothe adjudicative lawmaking to a significant degree with the same sort of legitimacy present in parliamentary lawmaking. The first feature we ignore is the fact that most judicial decisions are to a very great extent products not of the unilateral decree of a judge or panel of judges, but rather of a process of participation and debate among the parties to the case that greatly restricts the decisional options available to the court. In this sense, judicial decisions resemble the decisions made by a democratic legislature after debate and a fair hearing at which all relevant views have been aired. As such, the decisions of courts can be seen to bear some legitimacy with respect to the litigants before them, both from a proceduralist and from a functionalist perspective.

The second feature of adjudication that we ignore is the fact that the prospectively binding nature of many, perhaps most, judicially created rules is tied directly to the degree in which the parties who participated in the creation of those rules represented the interests of the parties who will be bound by them. Stare decisis binds only to the extent that parties to subsequent cases are situated similarly to the parties in precedential cases. The parties to precedential cases thus can be said to serve as interest representatives of subsequent litigants in much the same way that we expect our elected legislators to serve as interest representatives of their constituents. This form of interest representation extends the legitimacy of a judicial decision-legitimately measured by both proceduralist and functionalist standards-from the parties immediately before the court to later parties who will be bound by the precedential effect of the court's decision.

Together these features, participatory decisionmaking and interest representation, constitute a form of adjudicative lawmaking that I will refer to as adjudication as representation. Adjudication as representation can be seen as legitimate in a democratic way, at least to a meaningful extent, because it incorporates the concept of participation through representation into the adjudicative decisionmaking process. Let us see in more detail precisely how these mechanisms work.

\section{A. Participatory Adjudicative Decisionmaking}

[T]he distinguishing characteristic of adjudication lies in the fact that it confers on the affected party a peculiar form of participation in the decision, that of presenting proofs and reasoned arguments for a decision in his favor.

Lon Fuller 133

133. Lon L. Fuller, The Forms and Limits of Adjudication, 92 Harv. L. Rev. 353, 364 (1978). 
Writers often refer to adjudication as if it were a purely dictatorial process, governed in practice only by some combination of the particular judge's or panel's disposition, acumen, conscience, and political sagacity. The judicial decision is seen as a self-contained, autonomous entity arising solely from the judge's own will, an act of authority for which the judge and the judge alone is accountable. This is perhaps understandable, given legal academia's focus on the normative assessment of judicial decisions-what courts should be doing-rather than on the practical constraints imposed on those decisions. Ronald Dworkin's ideal judge Hercules, for instance, while normatively bound to principled consistency with previous legal decisions, is descriptively an all-powerful character, constantly presented with unsupervised choices of whether to decide a case wrongly or rightly and restrained in the real world only by his inclination and ability to choose correctly. ${ }^{134}$ Anyone familiar with constitutional and other public-law scholarship will recognize the same habit there: court decisions are treated as ministerial acts of isolated individuals, unaffected in substance by the processes employed in reaching them and attributable to "the Court" alone or, sometimes, to a single member or faction of "the Court." It is as if judges decided by muse or divine inspiration, spinning opinions out of whatever cloth happens to match their mood that day.

But judgments come from cases, and cases are more than abstract exercises in legal theory. Cases are the products of disputes among real people, and, not surprisingly, those same real people and their agents tend to be intimately involved in managing them. Court cases are contests, and judges often find themselves in the position of mere referee.

Indeed, Anglo-American adjudication is a fundamentally participatory enterprise. Judges may finish cases, but they do not initiate them or move them toward conclusion; they do not decide what facts need to be proven; they do not determine what legal arguments will be presented. Judges rule on motions, but they do not bring them; they respond to objections during testimony, but only rarely do they elicit testimony themselves; they hear arguments of counsel and read legal briefs, but they do not make or write them. All of this-all of the activity that drives adjudication forward, that defines the legal issues and determines what facts will animate them-is done by the litigants themselves, through their counsel. ${ }^{135}$ By the time the litigants and attorneys have done their jobs, the court's options for decision are in reality quite limited.

I do not mean to imply that everyone who has written about courts has ignored this participatory essence of adjudicative decisionmaking.

134. See Dworkin, supra note 11.

135. As the court rather pithily put it in McCargo v. Hedrick, 545 F.2d 393, 401 (4th Cir. 1976): "Ours is an adversary system of justice. . . . In our system lawyers worry about the whereabouts of witnesses. The court does not. Lawyers worry about proof. The court does not . . . . Lawyers get the case ready for trial. The court does not." 
One who did not was Lon Fuller, who, in his influential, posthumously published article "The Forms and Limits of Adjudication,"136 identified three conditions he felt were necessary for a decisionmaking process to be considered adjudicative. As paraphrased by Melvin Eisenberg in his comment on "Forms and Limits," these three conditions were:

(i) The adjudicator should attend to what the parties have to say.

(ii) The adjudicator should explain his decision in a manner that provides a substantive reply to what the parties have to say.

(iii) The decision should be strongly responsive to the parties' proofs and arguments in the sense that it should proceed from and be congruent with those proofs and arguments. ${ }^{137}$

Thus Fuller saw that adjudicative decisions actually are created in a very real sense by the litigants, not by the court: The court's duties of attention to the parties' arguments, explanation of its decision, and strong responsiveness to those arguments in fact limit the court's decision to an act of choosing between (or perhaps compromising between) alternatives presented by the contesting parties. The court has chosen the decision, but the decision itself has been authored by the litigants-to a significant degree, at least.

We call this mode of participatory justice "the adversary system," although the adversarial nature of the proceedings is simply one aspect (if arguably a vital one ${ }^{138}$ ) of the entire framework of party initiation, party presentation, and court responsiveness that makes the system participatory. It is not the only way to do adjudication. Other political systems, systems that generally place a much lower value on government by participation, also (not coincidentally) employ adjudicative procedures that are far less party-driven and are controlled to a much greater extent by the state in the person of the judge. Mirjan Damaška has demonstrated the strong connection between a polity's general philosophy of government and its chosen system of adjudication.139 Polities preferring individual decisionmaking over state control tend towards adjudicative procedures featuring party initiation, party control, and relatively passive

136. See Fuller, supra note 133.

137. Melvin Aron Eisenberg, Participation, Responsiveness, and the Consultative Process: An Essay for Lon Fuller, 92 Harv. L. Rev. 410, 411-12 (1978).

138. Fuller believed adversarial proceedings to be a necessary component of adjudication. See Fuller, supra note 133, at 382-85. Indeed, it is difficult to conceive of a system of adjudication that would involve meaningful participation by those to be affected by the decision and at the same time would not involve a great degree of adversariness. Adjudication implies the existence of a dispute that must be resolved, and the parties to a dispute will by definition be adverse to each other. Thus, their participation in the adjudicative proceeding could hardly be cooperative and still be meaningful qua participation. For a good survey of arguments for and against the adversary system, with a noticeable tilt in favor of it, see Stephan Landsman, Readings on Adversarial Justice: The American Approach to Adjudication, A.B.A. Sec. Litig. 1988.

139. See Mirjan R. Damaška, The Faces of Justice and State Authority: A Comparative Approach to the Legal Process (1986). 
judges, ${ }^{140}$ while polities preferring state decisionmaking over individual autonomy tend towards methods of adjudication involving state initiation of proceedings and extensive judicial control. ${ }^{141}$

The system of adjudication we choose, then, speaks volumes about our more general philosophy of government. In the Anglo-American tradition, we restrict the role of the judge to that of making "a choice between competing views, or a mediation among such views"; 142 to the parties who will be affected by the judgment we leave the definition and articulation of those views. Thus the litigants subject to a court decision are in a very real sense, as Edward Levi observes, "bound by something they helped to make." 143 This echoes our general preference for government through participation over government by fiat.

In the remainder of this section I do two things. First, I provide a hypothetical (but, I think, quite typical) example of the process of participatory adjudication in action. Then I discuss how the process of participatory adjudication produces democratic legitimacy according to the proceduralist and functionalist theories we examined in Part I.

1. Participatory Adjudication in Action. - Imagine a dispute between one individual, Smith, and another, Jones. Smith believes she has been injured in a legally cognizable way by Jones, and so she files a lawsuit against Jones in a state trial court of general jurisdiction. ${ }^{144}$ The first thing to note about the events so far is precisely who has initiated the legal proceeding: It is Smith, a private party with a claim of legal injury, not the court itself or any other government organ.

140. See id. at $109-40$.

141. See id. at 154-73.

142. Id. at 169.

143. Levi, supra note 11 , at 4.

144. See Fed. R. Civ. P. 3 (Commencement of Action), 7 (Pleadings Allowed; Form of Motions). Although we will suppose this hypothetical case to be before an imaginary state court, I will insert references to the relevant Federal Rules of Civil Procedure, Federal Rules of Appellate Procedure, or Federal Rules of Evidence (and, in some instances where the Federal Rules themselves are silent, to exemplary local federal court rules) at the appropriate places in the discussion to make sure that we have a grounding in the world of fact.

My hypothetical case is a civil lawsuit, but there is no reason to think that the model of participatory adjudication 1 outline here could not apply in the criminal context as well. As we shall see, the accuracy of the model depends upon (1) the extent to which each party in a real case is afforded a relatively equal chance to influence the outcome of the case, and (2) the extent to which the outcome of that case is authored to a significant degree by the litigants and their counsel. Of course, problems of inequitable ability to influence the outcome might arise more often in criminal cases, where one party always is the government and the other often is a defendant with limited resources. Where the deck is stacked against a criminal defendant (or indeed against any litigant, civil or criminal) in this way, participatory adjudication will be compromised, and the democratic legitimacy of the adjudicative process will be compromised as a result. This gives us yet another reason to deplore this kind of circumstance-as if any additional reason were necessary. In any event, a detailed exploration of the legitimacy crisis posed in such cases is beyond the scope of this Article. 
The second point of importance follows closely on the first. Smith's complaint, if properly drafted, states one or more legal theories about why she should recover damages from Jones and supports those theories with factual allegations. ${ }^{145}$ Again, the important steps of framing legal theories and offering facts for proof have been taken by the litigant Smith, not by the court itself.

Jones now files an answer to Smith's complaint. ${ }^{146}$ In his answer Jones does two things. First, he responds to Smith's factual allegations with factual allegations of his own, either in the form of admissions or denials of Smith's allegations or in the form of affirmative allegations designed to demonstrate his lack of liability to Smith. Second, Jones frames and articulates his own legal theories of why he should not be liable to Smith. Now the initial factual and legal issues between the parties have been joined, and, of course, the court has played little or no part in framing these issues.

Next, the parties engage in discovery to further elicit potentially relevant facts. ${ }^{147}$ To be sure, by now the court has become involved in the case to some extent; there has been a preliminary scheduling conference before the judge to set deadlines for joinder, pleading amendments, dispositive motions, and completion of discovery, as well as a tentative trial date. ${ }^{148}$ The court may even be empowered by statute to encourage settlement, simplification of legal and factual issues, and so on. ${ }^{149}$ But the court's only real coercive power is the setting of deadlines by which certain steps of the litigation must be completed. The judge cannot force the parties to settle, nor can she eliminate on her own motion what she believes to be frivolous legal contentions or factual allegations. Under these conditions, discovery proceeds, with each party serving and answering interrogatories ${ }^{150}$ and document requests ${ }^{151}$ and taking depositions. ${ }^{152}$ The content of each party's discovery upon the other, and upon third parties, is primarily up to the litigants themselves. ${ }^{153}$ The court can

145. See Fed. R. Civ. P. 8(a) (Claims for Relief), 9 (Pleading Special Matters), 10 (Form of Pleadings).

146. See Fed. R. Giv. P. 7-8, 10, 12 (Defense and Objections).

147. See Fed. R. Civ. P. 26-37 (Depositions and Discovery).

148. See Fed. R. Civ. P. 16 (Pretrial Conferences; Scheduling; Management).

149. See id.

150. See Fed. R. Civ. P. 33 (Interrogatories to Parties).

151. See Fed. R. Civ. P. 34 (Production of Documents and Things and Entry Upon Land For Inspection and Other Purposes).

152. See Fed. R. Civ. P. 30 (Depositions Upon Oral Examination).

153. Under the 1993 amendments to the discovery provisions of the Federal Rules, each party is required, "without awaiting a discovery request," to provide a fairly broad spectrum of basic information to the other party. Fed. R. Civ. P. 26(a). This is a significant departure from previous practice, and its equivalent bas not yet been adopted by most states. See Rogelio A. Lasso, Gladiators Be Gone: The New Disclosure Rules Compel a Reexamination of the Adversary Process, 36 B.C. L. Rev. 479 (1995) (providing an overview of the new rules and anticipated problems). Indeed, many federal courts have promulgated local rules "opting out" of all or part of the new discovery procedures and 
resolve disputes between the parties on the subject, but it is entirely unable to ensure (and probably will not even suggest) that the litigants pursue a particular course of inquiry.

After some months of discovery, the defendant Jones brings a summary judgment motion. ${ }^{154}$ Jones's decision to bring the motion was entirely his own and his counsel's, and his theories of why he is entitled to summary judgment are wholly the product of his counsel's own factual investigation and legal research and analysis. The court did not, and indeed could not, bring the motion on its own initiative.

A briefing schedule on the summary judgment motion is set:155 Jones, as the movant, files his supporting brief first, and in it he presents a number of legal theories why he is entitled to judgment and supports them with references to the pleadings and the facts elicited during discovery. ${ }^{156}$ Smith then files an opposition brief in which she responds to the legal and factual arguments put forth in Jones's brief. ${ }^{157}$ Finally, Jones files a reply brief in which he responds to Smith's arguments and reiterates his own basis for relief. ${ }^{158}$

The court now has before it a fully briefed motion for summary judgment filed by Jones. The court has two choices: It may either grant or deny the motion. (It may also be possible for the court to split the difference by granting the motion in part and denying it in part.) Theoretically, of course, the court could make its choice on a whim, or on a theory entirely separate from any advanced by either of the litigants. But the court probably will consider itself to be much more constrained than this. Unless it wishes to renounce centuries of Anglo-American juridical tradition, the court must articulate reasons for whatever decision it makes. The most complete and readily available sets of reasons are those offered by each of the parties and contained in their briefs and, perhaps, their oral arguments. This is an enormous practical incentive for the court to avoid setting off on its own and deciding the motion according to some independent theory. And even aside from this incentive, the court is likely to feel, with Fuller, that its decision must be "strongly responsive" to the arguments of the parties in order to qualify as legitimate adjudication. Finally, since the court is required by rule to determine whether

continuing under the old version of the rules. See, e.g., N.D. Ill. R. 5.00(C) ("Except to the extent otherwise directed by order of the court, the automatic disclosure provisions set out in F.R.Civ.P. 26(a) (1) shall not apply.").

The new disclosure rules represent a notable retreat from an adversarial approach to the proof of facts in adjudication, as they eliminate much of the strategic element of discovery. To what extent they affect the basic process of framing the legal and factual issues to which discovery is relevant is open to question.

154. See Fed. R. Civ. P. 56 (Summary Judgment).

155. See, e.g., N.D. Ill. R. 12(O).

156. See, e.g., N.D. III. R. 12(M).

157. See, e.g., N.D. IIl. R. 12(N).

158. See, e.g., N.D. Ill. R. 12(M). 
there is any "genuine issue as to any material fact," 159 it thus is further constrained to base its decision upon the facts elicited by the parties during discovery.

In other words, the discretion of the court deciding Jones's summary judgment motion is, to a very significant degree, reduced to a choice between adopting Smith's point of view (for all or some of the reasons put forward by Smith) and adopting Jones's point of view (for all or some of the reasons put forward by Jones). The court cannot really create its decision; it can only choose between two alternative decisions authored by each of the parties.

Let us pause for a moment to acknowledge that this is probably a somewhat simplistic view of the court's decisionmaking process. The positions of Smith and Jones may be very far apart, and in order to decide between them the court may have to choose between fundamentally different conceptions of, say, law or morality. (Indeed, the court may have to make such a choice even if the litigants' positions are rather close together.) This choice may be animated at least in part by the judge's own ideals, predispositions, intelligence, politics, conception of her social role, or other factors that cannot be said to have been authored or caused by the litigants. What is more, the litigants' conduct during the proceedings-their choice of legal arguments and factual proofs, for instancemay have been influenced in part by their perceptions (or those of their attorneys) of what kinds of arguments and proofs would be likely to influence this particular judge. In these senses, the judge undeniably has participated in the creation of her decision.

But the important point to remember, and what I am trying to illustrate here, is simply that the decision often (perhaps usually) will be largely - to a significant (if not total) degree-the product of the voluntary, self-directed activities of the litigants themselves. The judge plays a role, yes, but it is far from the autonomous, dictatorial one that it is so often assumed to be. The decisionmaking process in a court case has much more to do with the participation of the litigants than with the authoritative fiat of the judge. And, importantly, the stricter the conception of the adversary system that is adhered to, the smaller will be the realm of judicial authorship of the resulting decision.

So, constrained in this significant (if not absolute) way, the court decides for Smith and denies Jones's motion. The court memorializes its ruling in a minute order and gives its reasons, which echo Smith's arguments, in open court.

Having survived summary judgment, Smith's claim now proceeds to trial. Let us suppose for simplicity's sake that the parties have agreed to a bench trial, although a jury trial would not substantively affect our analysis. As a matter of tradition, lawyers for each party are given the opportunity to present an opening statement to the trier of fact (here, the judge) 
laying out that party's theory of the case and what he or she intends to prove. Then the trial proceeds with the taking of oral testimony, ${ }^{160}$ first from witnesses called by the plaintiff, Smith, and then from witnesses called by the defendant, Jones. Although the court may call and examine witnesses on its own initiative ${ }^{161}$ and will exercise "reasonable control" over examination of witnesses by counsel to prevent delay, harassment, and the like, ${ }^{162}$ the eliciting of testimony and the presentation of other evidence are primarily directed by the parties themselves through their counsel.

After each litigant has had the opportunity to present his or her case, attorneys for Smith and Jones give closing statements to the court in which each summarizes the evidence and reiterates the legal basis for a ruling in his or her client's favor. As is often the case in a bench trial, the judge also asks each party to file a post-trial brief, which performs essentially the same functions as closing argument in more detailed form.

Now the court is again in the position of having to make a decision. And, as with the summary judgment motion, the court's decision will not be pulled from the clear blue sky. It must be firmly grounded in the now substantial body of evidence presented at the trial, and it must be strongly responsive to the legal theories advanced by the parties in their pleadings, briefs, and oral arguments. Once again the court is in the position of having to choose between two alternatives (or, at most, from among several reasonable variations of those alternatives) that have been developed not by the court, but by the parties. Even if the court is inclined to develop and rely upon its own substantive reasons for a decision, reasons that have not been offered by the litigants-an inclination that busy courts deciding well-litigated cases are unlikely to act upon very often-its alternatives nonetheless are cabined by the legal and factual context in which the litigants have placed it. The court cannot, for example, determine on its own initiative that Jones is liable for trespass when Smith has sued him only for breach of contract.

The court rules in favor of the plaintiff, Smith, memorializing its decision in a fairly lengthy opinion that makes frequent references to the evidence and largely incorporates the legal theory advanced by Smith in her briefs and at trial. Jones promptly appeals to the intermediate state appellate court.

The appellate court, as a court of review, does not take additional evidence or entertain further factual allegations. Instead the appellate court will be bound in its decision by the evidence produced during discovery and at trial, and in some instances even by the trial court's interpretation of that evidence. ${ }^{163}$ But the appellate court is free to make its own legal determinations, and so it requires Jones and Smith (through

160. See Fed. R. Civ. P. 43 (Taking of Testimony).

161. See Fed. R. Evid. 614 (Calling and Interrogation of Witnesses by Court).

162. See Fed. R. Evid. 611 (Mode and Order of Interrogation and Presentation).

163. See Fed. R. App. P. 10 (The Record on Appeal). 
their attorneys) to submit briefs stating their legal and factual arguments 164 and to give an oral presentation before the court summarizing their positions and answering the panel's questions. ${ }^{165}$ All of this Jones and Smith do.

Now the appellate court must make its own decision. While the trial court was bound to follow the appellate court's precedents, the appellate court is not strictly bound to follow its own precedents, and so in that sense its discretion is broader than the trial court's. But like the trial court, the appellate court cannot weave its decision out of whole cloth. It too is significantly constrained by the fact-proving and law-arguing work the two litigants have been doing since the beginning of the case many months ago. It cannot go outside the elicited evidence-indeed it is more strictly tied to that evidence, through the paper record before it, than the trial court was-and it must make its decision strongly responsive to the reasoned arguments of the parties. Even if it decides to reject one of its own precedents or to interpret it in an especially restrictive or expansive way, it is likely to do so only at the suggestion of one of the parties before it. And the appellate court probably will ignore legal arguments that were not made in the trial court below. In short, like the trial court, the appellate court is mostly restricted to a choice between two competing results and the two competing legal theories that support them. Its ability to author the substance of its decision is severely limited.

Like the trial court, the appellate court rules for Smith, writing its own lengthy opinion which, like that of the trial court, makes frequent reference to the evidence (the record) and incorporates much of the reasoning contained in Smith's briefs and arguments. Jones now has two strikes against him, and he decides to forego the time and expense of a discretionary appeal to the state supreme court. Smith has won; Jones has lost; and, thanks to the decision of an appellate court, presumably a significant transfer of wealth will take place between the two.

What, then, has happened in the case of Smith $v$. Jones? Two successive courts have rendered decisions in favor of Smith, but neither court has had much real control over the substance of the decision it has rendered. From the beginning, Smith and Jones have manipulated the ultimate resolution of the case, ensuring that the appellate court's final decision would fall within a very narrow range of possibilities-possibilities defined by the facts elicited by the parties and the legal theories advanced by them. Had Smith failed to prove one crucial fact or ignored a single important line of argument, the court might have decided for Jones; had Jones been more diligent in discovery or written a more persuasive brief, the court might have decided against Smith. Thus the ultimate decision has in a very genuine way been produced by the litigants; they have par-

164. See Fed. R. App. P. 28 (Briefs).

165. See Fed. R. App. P. 34 (Oral Argument). 
ticipated significantly, even predominantly, in the authorship of that decision.

2. The Democratic Legitimacy of Participatory Adjudication. - The process of participatory adjudication we have seen at work in Smith $v$. Jones can, with respect to the litigants who will be bound by a court's decision, claim the same sort of democratic legitimacy that we locate in the process of lawmaking by deliberation in a representative legislature. We can see this by analyzing, briefly, participatory adjudication through the lenses of both proceduralist and functionalist democratic theory.

a. Proceduralist Legitimacy. - Recall that there are two strains of proceduralist democratic theory: deontological theories, which view the participatory decisionmaking procedures characteristic of democracy as inherently good, and consequentialist theories, which hold that participatory decisionmaking procedures have good effects (but effects unconnected with the quality of the substantive decisions the procedures generate).

Deontological proceduralist theories hold that the process of significant individual participation in government decisionmaking is inherently good, usually as an expression of the principle of individual autonomy. ${ }^{166}$ The process of participatory adjudication can be seen as inherently good in the same ways. Litigants before a court participate in creating the decisions that will affect them just as voters in a representative democracy do-and probably to a greater extent. While there will always be some realm of judicial discretion, the decisions on the merits produced through the adversary system will always depend to a significant degree upon the activities of the litigants themselves. In contrast, the voice of the voting constituent in an election is just one among many.

Participatory adjudication thus satisfies the concerns of deontological theorists in at least as great a degree as representative legislation does. Participation in adjudicative decisionmaking preserves the negative autonomy of the litigants by ensuring that neither litigant will have disproportionate power over the other, that neither will serve as "Judge in his own Case": 167 each litigant is equally allowed (and equally obligated) to submit proofs and reasoned arguments for decision by a neutral judge. It also preserves negative autonomy by transforming the coercive decision of the court into an act of constraint by each litigant's consent: Although there is a loser as well as a winner in adjudication, we can say, as in parliamentary legislation, that the party whose proposal is rejected has nonetheless consented to the decision as long as she was given the same full opportunity as her opponent to argue her case. As David Gauthier has written of parliamentary lawmaking, participatory adjudication

offers each person the opportunity to advance whatever proposal he pleases, but requires him to submit it to ... critical consid- 
eration ... so that its adoption depends on his being able to give it a reasoned grounding .... Thus no one ... has any basis for complaining that he was unable either to advance or to defend his concerns in ways available to [the opposing party]. ${ }^{168}$

Consequentialist proceduralist theories hold that the process of individual participation in government decisionmaking is good because it serves some valuable nonpolitical social or individual ends-development of the human character and encouragement of an enterprising public spirit, for example. ${ }^{169}$ It might be thought that the strain of consequentialism that is concerned with developing the individual human character would hardly condone adversary adjudication, because that strain emphasizes qualities of "well-doing" and public-mindedness that seem absent from the typical self-interested courtroom battle. But this humanistic consequentialism, especially as propounded by Mill, also emphasizes the importance of participation for the development of qualities like "industry, integrity, justice, and prudence"170_-individualistic attributes that might well be fostered by participatory adjudication. More importantly, the humanistic benefits of participatory adjudication must be assessed in comparison to its alternative: a system of adjudication by judicial fiat akin to the inquisitorial systems present in civil-law countries and to a greater degree in the former communist bloc. ${ }^{171}$ Participatory adjudication at least provides some of the humanistic benefits extolled by Aristotle, Rousseau, Mill, and others; adjudication by judicial fiat provides none of them.

The second major strain of consequentialism, the Tocquevillian argument from indirect social benefits, would seem to support participatory adjudication on the same grounds by which it supports representative democracy in general. The "restless activity, superabundant force, and energy"172 that Tocqueville saw as a byproduct of participatory government, of being called upon to actively make decisions about one's destiny in a social context, appears to transpose quite well to the process of participatory adjudication, where each litigant must actively vindicate her own rights and interests in order to see them fulfilled. Again, the alternative, adjudication by judicial fiat, can provide scant encouragement for the development of these energetic qualities.

So participatory adjudication can be seen as democratically legitimate from a proceduralist standpoint. Indeed, the direct, meaningful participatory role that process confers upon the affected litigants seems to address proceduralist concerns of autonomy, humanism, and social dy-

168. David Gauthier, Constituting Democracy, in The Idea of Democracy, supra note 67 , at 314,321 .

169. See supra Part I.A.2.

170. Mill, Representative Government, supra note 61, at 201.

171. On some of the distinctive features of inquisitorial systems and their relationship to the theoretical underpinnings of the state, see Damaška, supra note 139, at 154-73.

172. Tocqueville, supra note 29 , at 244 . 
namism in a more salient and significant way than the relatively anonymous mechanism of periodic elections does. Participatory adjudication means that a court decision always will be directly attributable, at least in large part, to the active participation of the people who will be affected by that decision.

b. Functionalist Legitimacy. - Participatory adjudication also can claim functionalist legitimacy in the same ways that democratic parliamentary government can. Like representative democracy itself, participatory adjudication allocates much of the decisionmaking power to those who will be most affected by a decision: the litigants who will be subject to a court's order. Participatory adjudication necessarily requires each litigant to be "the only ... gnardian of his own rights and interests." 173 Similarly, participatory adjudication ensures that a greater diversity of interests will be represented in the decisionmaking process than if court decisions were made by judicial fiat, thus increasing the chances that the resulting decisions will adequately respond to and balance those interests.

It might at first appear that participatory adjudication does nothing to encourage the participation in decisionmaking of especially talented and capable decisionmakers: Should we not presume that a typical judge is likely to be a more talented decisionmaker than a typical litigant? The answer is threefold. First, there is not necessarily any reason to make this assumption, and indeed the litigants may be more skillful decisionmakers than the judge with respect to the given subject matter of the litigation. (This is simply the argument from allocation of decisionmaking power restated.) Second, participatory adjudication does not cut the judge out of the decisionmaking process altogether; instead it supplements the judge's own decisionmaking powers with those of the litigants and their attorneys, thereby increasing the chances that skillful decisionmaking will occur. (This is a restatement of the argument from assertion of a diversity of interests.) Finally and most important, participatory adjudication in effect creates more talented and capable decisionmakers: Through the presentation of proofs and reasoned arguments by both sides, it gives the judge empirical, theoretical, and analytical materials to which she might not have access in a system of decisionmaking by judicial fiat.

Perhaps most saliently of all, participatory adjudication is the essence of decisionmaking by reasoned deliberation among opposing viewpoints. In Cass Sunstein's words, an important functionalist justification of democracy is the belief that " $[t]$ hrough confrontation among people who disagree, errors of fact may be revealed as such," 174 that the best decisions are reached through "reasoned debate," by assessing "'the force of the argument[s] " " for all sides. ${ }^{175}$ What could be more true to this ideal than

173. Mill, Representative Government, supra note 61 , at 224 .

174. Sunstein, Democracy, supra note 97, at 243.

175. Id. at 245. 
adversary litigation, the paradigm of a decisionmaking procedure that relies on confrontation and reasoned debate among competing interests?

Thus participatory adjudication can be seen as legitimate according to functionalist theories of democracy as well. It produces decisions through a process of reasoned argument among those most concerned with the issues being decided. As such, functionalism predicts that participatory adjudication is more likely to produce good decisions than a system of adjudication by fiat.

c. A Word of Caution. - With respect to the litigants immediately affected by a court decision, then, participatory adjudication ensures that the decision will carry a large measure of the same kind of legitimacy that laws generated by a representative legislature possess. But a forceful caveat is in order. To say that participatory adjudication creates meaningful democratic legitimacy is not to say that the adjudicative process is precisely analogous to the process of parliamentary legislation, or that adjudicative decisionmaking always (or even often) will be just as legitimate from a democratic perspective as parliamentary decisionmaking usually is. The simple fact, after all, is that there is no one in parliamentary decisionmaking analogous to the judge. As long as someone playing the role of judge, of ultimate decisionmaking authority, exists in adjudication, there is always the chance that a measure of rule by fiat will creep into the adjudicative process. Judges, after all, are human, and they are likely to do things that human decisionmakers sometimes do: favor one litigant over another for irrelevant reasons, or insert their own ideology into the decision, or simply sleep through one party's argument. In parliamentary decisionmaking, by contrast, rule by fiat cannot gain even the smallest foothold. As long as everyone is given a meaningfully equal vote, no one can wield arbitrary power over anyone else. There is no wigged eminence who has the final word.

Participatory adjudication, that is, cannot completely remove the possibility of judicial discretion. But let us imagine a case in which participatory adjudication operates in its purest form: The judge, in making her decision, acts only to choose from between competing theories of the case offered by the litigants and exercises no will of her own beyond that strictly necessary to make this choice. In such a case-a hypothetical one, to be sure-can we really say that the presence of a judge makes any difference from the standpoint of democratic legitimacy? The judge, it is true, has chosen to reject the arguments of one litigant and to render a decision favorable to the other. But this is precisely what the citizen (or her representative) does in the process of parliamentary legislation. When a voter in a popular election selects one candidate over another, or when a legislator in Congress votes to enact a contested statute into law, that decisionmaker, like a judge, has chosen to reject the arguments of one set of people and to render a decision favorable to another. The only real difference is that in adjudication it is one person (or perhaps a 
small group of people), not hundreds, thousands, or millions, that is making the choice. The losers are bound just the same.

No, it is not the existence of the judge itself that threatens to make adjudication nondemocratic; it is the potential, often realized, for the judge to exercise disproportionate power in the decisionmaking process. We are not bothered by the idea of subjecting important policy decisions to the votes of millions of self-interested decisionmakers, because we know that no one else's vote will count for more than our own. But we are bothered by the idea of subjecting such decisions to the authority of one disproportionately powerful judge or panel of judges, because we are justifiably afraid that our "vote" will not count for as much as theirs will.

Participatory adjudication cannot eliminate this fear; it contains no foolproof safeguard like the one-person, one-vote electoral system. But recognizing its existence can tell us that judges are not, or need not be, as disproportionately powerful as we might be conditioned to think. It can remind us that those who will be most affected by judicial decisions, the litigants themselves, can play as great or nearly as great a role in the creation of those decisions as the judge can.

$\mathrm{Be}$ this as it may, however, court decisions may have effects extending beyond the litigants that helped to produce them: They may affect future litigants (or potential litigants) through the doctrine of stare decisis. Can we somehow say that those extended effects bear some democratic legitimacy as well?

\section{B. Interest Representation Through the Common Law Method}

[Stare decisis results in] a form of representation that is specific to the judicial branch: the party who participates in a [court case] represents himself and all others who are in a similar position. Thus, the common law method has salutary procedural consequences in that it brings into the legal decisionmaking process precisely those persons who bear the impact of a decision.

\section{Lea Brilmayer 176}

Court decisions, we know, can become rules of sorts. What we call "the common law method" means that cases are decided by analogy, by comparison of their facts to the facts of previously decided cases and conformity of their results to the results of those past cases. ${ }^{177}$ To the extent

176. R. L. Brilmayer, Judicial Review, Justiciability and the Limits of the Common Law Method, 57 B.U. L. Rev. 807, 817 (1977).

177. The extant literature relating to the common law method, analogical legal reasoning, stare decisis, and the like would of course fill a library. A few good examples are: Levi, supra note 11; Karl N. Llewellyn, The Bramble Bush: On Our Law and Its Study 56-76 (1960); Precedent in Law (Laurence Goldstein ed., 1987); Cass R. Sunstein, Legal Reasoning and Political Conflict 13-34, 62-100 (1996) [hereinafter Sunstein, Legal Reasoning]; Larry Alexander, Constrained by Precedent, 63 S. Cal. L. Rev. 1 (1989); Scott Brewer, Exemplary Reasoning: Semantics, Pragmatics, and the Rational Force of Legal 
a court purposely conforms its decision to that of a previous court in this way, the parties are bound by the decision in the previous case; that decision has become a rule governing the outcome of the subsequent case. And this rule is likely to persist not merely as a rule of decision-to be followed by courts in deciding subsequent cases-but as a rule of conduct as well, to be followed by individuals and entities rationally conducting their everyday affairs in ways they believe least likely to result in courtimposed penalties or most likely to result in court-bestowed gains. ${ }^{178}$ Court decisions thus can serve as rules in much the same way that statutes do, encouraging and discouraging certain kinds of conduct with the promise that such conduct will bear particular legal consequences. ${ }^{179}$

We have seen that court decisions can claim a significant measure of democratic legitimacy with respect to the litigants immediately before the court that produces them. Those litigants have participated in creating the decision, and so, from a proceduralist and from a functionalist perspective, that decision may legitimately bind them. But what of the litigants before a subsequent court that uses the original decision as precedent? And what of those private (or, indeed, public) actors who conform their conduct to the original decision in anticipation that they might become litigants? They have not actually participated in the creation of the decision that, for them, has become a binding rule. How then can they be bound by that rule in a democratically legitimate way?

The answer takes us back to the idea of interest representation, of representation in the creation of coercive rules by agents who share a common bond of interest with their principals. In order to understand how interest representation works to extend democratic legitimacy to adjudicative rulemaking, we first need to understand how adjudicative rulemaking through the common law method works. Then we will be able to see how the common law almost invariably produces an especially accurate form of interest representation when it binds litigants to the results of previous cases.

1. The Nature of a Common Law "Rule." - The common law advances case by case, reasoning by the process of analogy to, and distinction froin, the facts of previous cases. Common law precedents bind future litigants only to the extent that they control by analogy. In the common law, the

Argument by Analogy, 109 Harv. L. Rev. 923 (1996); Peters, supra note 34; Frederick Schauer, Precedent, 39 Stan. L. Rev. 571 (1987); and Cass R. Sunstein, On Analogical Reasoning, 106 Harv. L. Rev. 741 (1993).

178. On the difference between decision rules and conduct rules, see generally Meir Dan-Cohen, Decision Rules and Conduct Rules: On Acoustic Separation in Criminal Law, 97 Harv. L. Rev. 625 (1984) (tracing history and discussing importance of distinction between decision and conduct rules).

179. See generally Richard A. Posner, Economic Analysis of Law $\$ 8.1$, at 251-55 (4th ed. 1992) (detailing the economic justifications of common law doctrines); Frederick Schauer, Opinions As Rules, 62 U. Chi. L. Rev. 1455 (1995) (arguing that the language of judicial opinions justifiably resembles that of statutes and legislation). 
"rule" of a case is the result of that case-no more and no less. As we will see, this fact is the engine that drives adjudication as representation.

In order to understand how the common law works to constrain future courts and litigants, it will help to note a crucial difference between a common law rule and a typical statutory rule. A typical statute does two things: (1) it specifies the set of factual conditions necessary for a certain result to obtain, and (2) it dictates that no other factual conditions may be considered relevant to whether that result obtains. It is thus an "if and only if" rule: It requires a certain result if a certain set of facts exists (regardless of what other facts might also exist), and it requires a different result if all of those facts do not exist (again, regardless of what other facts might also exist).

For instance, to adapt an example I have used elsewhere in a different context, ${ }^{180}$ imagine a simple statute regulating admission to the bar of a particular jurisdiction. The statute provides that any person who (a) has passed that jurisdiction's bar exam and (b) is of "good moral character" is entitled to practice law in the jurisdiction. This statute in essence contains three complementary but separate rules: (1) the positive rule that anyone who meets both factual conditions (passing the bar and good moral character) must be allowed admission to the bar; (2) the negative rule that anyone who does not meet both factual conditions must not be allowed admission to the bar; and (3) the negative rule that no other factual conditions-the applicant's hair color, her birthdate, her taste in clothing, whatever-may be considered in deciding whether to admit her to the bar. The statute, considered as a decision rule, thus binds at both ends, by positively requiring bar officials to admit persons under certain conditions, and also by negatively requiring them to allow admission only under those conditions and to consider only those conditions in making their admissions decisions.

Common law precedents have a different effect. Like typical statutes, they dictate that on a certain set of factual conditions, a certain result must obtain. But unlike statutes, they do not dictate either that the same result not obtain without those conditions, or that no other factual conditions be considered relevant to whether that result obtains. They bind positively but not negatively; they are "if-then" but not "if and only if" rules.

Suppose a court must decide whether a certain kind of injury is reasonably foreseeable and thus compensable in a tort lawsuit arising from an automobile accident. The plaintiff is the estate of a decedent who died after the ambulance in which he was riding (after suffering a heart attack) was negligently struck by the defendant's car; the decedent died not from injuries suffered in the collision, but because he did not reach the hospital in time as a result of it. The court rules that on these facts 
the decedent's injury was reasonably foreseeable to the defendant, and it allows recovery.

Like a statute, this court decision has enumerated a set of facts on which a certain result must obtain. The result is tort liability (or, more precisely, the ability to state a tort cause of action); the facts are those relied upon by the court in deciding the case, including, for instance, the fact that the ambulance's flashing lights and siren were on (indicating an emergency), the excessive speed at which the defendant was driving (making it more likely that an accident would disable the struck vehicle), and the relative lack of traffic on the street where the collision occurred (making it more likely that the defendant was aware of the ambulance qua ambulance). By the common law method, stare decisis dictates that this decision be followed-that is, that the same result (potential liability) be reached-in subsequent cases presenting an equivalent set of facts. In this sense the decision establishes a positive rule much like that established by a statute: It dictates that, in the future, the presence of a certain set of factual conditions necessitates a certain result.

But in another sense the decisional rule produced by the case is very different from a statutory rule. Stare decisis requires that future identical (or closely similar) cases bear the same result as this precedential case; but it does not require that all future cases without all the facts of the precedential case not bear the same result, nor does it limit the range of potentially relevant factual conditions to those specific facts relied upon by the precedential court. A subsequent court might, consistent with stare decisis, impose liability in circumstances where (unlike the precedential case) the ambulance's lights were not flashing; or it might decide not to impose liability where, despite the presence of all the material facts relied upon by the court in the precedential case, an additional fact (the fact, for instance, that the decedent had suffered a broken leg rather than a heart attack) is held to have made the injury less foreseeable. A subsequent court, to the extent the facts before it are materially dissimilar to those of the precedential case, is bound neither to reach the same result as in the precedential case nor to reach a different result than in the precedential case. To the extent of the factual dissimilarity, the subsequent court (and the litigants before it) simply are not bound at all.

All of this is not to say, however, that courts and litigants in subsequent cases are not in some sense constrained by a precedent merely because the facts of the two cases are materially dissimilar. A dissimilar precedent still can bind in two ways. First, it can bind a fortiori: It can determine the results of dissimilar subsequent cases in which the facts nonetheless provide as strong or stronger an argument for the result of the precedential case than in the precedential case itself. Stare decisis, that is, extends the result of a particular case to all those cases, and only 
those cases, in which the facts support the same result with equal or greater force. ${ }^{181}$

From this perspective, the decision in our ambulance accident case would compel the same result in a case with materially similar facts or in a case in which the same material facts obtain but an additional fact-say, the fact that the ambulance was pulling into the hospital driveway at the time of the accident-further supports liability. But the decision would not compel the same result in weaker cases like the one in which the ambulance's lights were not flashing or the one in which the decedent originally had suffered only a broken leg. In such weaker cases, the field remains open; the rule of the precedential case does not determine the subsequent case's outcome. That outcome is a matter for reasoned argument by the parties and, ultimately, decision by the court.

Note, of course, that the threshold question of whether the facts of a subsequent case support the result of the precedential case with equal or greater force also is a matter for the proofs and reasoned arguments of the litigants in the subsequent case. Whether and to what extent a precedent will constrain, then, is not static or given, but is a product itself of participatory adjudication.

The second way in which a dissimilar precedent can constrain is to set a floor below which the result of a subsequent case cannot go. Even in cases in which the facts do not support the result of a precedential case with equal or greater force, the court in the subsequent case is not free to reach just any old result; the result still must be consistent with that of the precedential case. Thus the court in the subsequent case cannot deny liability altogether on the ground that drivers who strike ambulances are not able to reasonably foresee indirect injuries to their occupants as a matter of law. That issue already has been decided a certain way by the precedential court, and the subsequent litigants are not free to relitigate it. Their freedom extends only so far as the facts of the subsequent case are materially different from the facts of the precedential case.

A final point is that, absent strict constraint by virtue of similarity to the material facts of a precedential case, arguments from broad analogy or principle based upon the precedential case may still have some persuasive force. When the court is not bound by precedent to reach a certain result, a litigant is free to argue for the result she favors by claiming that the case is similar enough in general ways to one or more previous cases so that, although the court is not strictly bound to reach a result equivalent to those of the previous cases, the fact of similarity strongly supports reaching that result. Such an argument might flow, explicitly or tacitly, froin the same premises of consistency that underlie the doctrine of stare decisis itself: consequentialist notions of predictability, stability, efficiency, protection of expectations, and the like, or deontological no-

181. This description of stare decisis is, I think, what Larry Alexander has referred to as the "pure result model" of precedent. See Alexander, supra note 177, at 29-30. 
tions of equality or integrity. ${ }^{182}$ The litigant might also frame her argument not in terms of broad factual similarities between cases but in terms of principle: She might claim that one or more previous cases have produced or recognized a principle that also applies in her case to require a certain result.

These uses of precedent-arguments from broad analogy and arguments from principle-become legitimate when, and to the extent that, it is determined that no precedent is strictly controlling because no precedent has facts that are materially equivalent to those of the subsequent case. In such circumstances, less direct, more general uses of precedent become part of the reasoned arguments presented by the parties in favor of one or the other result; they serve as tools of participatory adjudication.

Of course, these kinds of arguments do imply some degree of constraint over the subsequent court: A court might be said to be constrained to reach the result supported by the best arguments from broad analogy and principle (although other types of arguments, such as arguments from policy, might also play a role in the court's decision). Indeed, one of the most influential extant theories of adjudication, Ronald Dworkin's theory of law as integrity, posits that courts are constrained by broad analogies and principles in this way. ${ }^{183}$

But the question of whether courts are in fact constrained by such arguments in a way similar to (though not in the same degree as) their constraint to follow on-point precedents need not concern us from the standpoint of adjudication as representation. This is true in part because of the participatory nature of adjudication in the subsequent, potentially constrained case; as we shall see, ${ }^{184}$ litigants in subsequent cases are able in a sense to "elect" their representatives by choosing, through reasoned arguments, which precedents control, and this same process operates to determine which precedents might control in the looser fashion dictated by broad analogy and general principle. It is true more fundamentally because, even under a holistic Dworkinian theory of constraint, the constraining force of a given precedent grows ever smaller as the level of factual similarity between that precedent and subsequent cases decreases. Thus subsequent litigants can be said to be constrained by a precedent only so far as they are similarly situated to the parties in the precedential case-that is, only so far as the broad analogies or principles deemed to govern them stem from cases with similar facts. The persuasiveness of the analogy or principle shrinks as the factual similarities become more attenuated.

182. Elsewhere I have argued that deontological arguments in favor of consistency, specifically arguments from equality and arguments from integrity, necessarily fail. See Peters, supra note 34, at 2055-110.

183. See Dworkin, supra note 11 , at 225-312. I have critiqued aspects of this theory in Peters, supra note 34, at 2073-112.

184. See infra Part II.B.3.b. 
That, then, is the nature of a common law rule. Unlike most statutory rules, it is not a"double-edged sword; it dictates results in cases of similarity but not in (most) cases of difference. Instead of producing comprehensive rules, the common law proceeds case by case, ${ }^{185}$ binding future litigants only through the force of analogy. A common law rule is simply the mandate that the decision in a subsequent case not contradict the result of a prior one.

I am not claiming that courts always act precisely in the way I have described. I am simply claiming that my description captures the essential character of the common law with respect to binding rules. To the extent courts do not respect this essential character, adjudication as representation will be compromised (although other legitimate ends may be served); but we will cross that bridge when we come to it. ${ }^{186}$

2. Stare Decisis and Interest Representation. - The fact that the common law produces and enforces "rules" in the way I have just described creates a dynamic of interest representation between the parties to precedential cases and the parties to subsequently constrained cases.

Recall that proceduralism favors representation by someone who is similarly situated to her constituents in important ways, who is enough like them that it is probable she shares many of their core viewpoints and interests. ${ }^{187}$ Similarity of situation between representative and constituent reinforces the coercive power of the polls because it provides the representative with an independent, self-serving reason to act in the constituent's best interests. Thus a true interest representative, a representative who is so similar to her constituents that their interests overlap on a significant number of central issues, is more likely than a representative concerned merely with reelection to produce legislation satisfactory to her constituency.

Likewise, functionalism favors this sort of interest representation not only because it increases the likelihood that a representative will truly represent the distinct characteristics of her constituency, but also because it allows the representative to exercise her own independent judgment in the way that her constituents likely would have exercised theirs in the same position. ${ }^{188}$ Interest representation allows the representative the necessary freedom to act according to her own conscience while retaining the essentially representative nature of her conduct, because it ensures that her conscience will resemble the consciences of her constituents. It thus promotes the character of democracy as a process of reasoned deliberation among diverse, often conflicting viewpoints.

185. For a related discussion of the procedural distinctions between adjudicative and parliamentary decisionmaking with respect to the issue of decisionmaking consistency, see Peters, supra note 34 , at 2081-84.

186. See infra Part II.C \& Part IV.

187. See supra Part I.C.2.a.

188. See supra Part I.C.2.b. 
Now consider the operation of the common law method, which requires a court to conform its decision to that in a previous case only to the extent that the facts of the two cases are materially similar. The simple but crucial fact about this method of constraint is that material similarity between the facts of the two cases means material similarity between the situations of the parties in each case. If the plaintiff in subsequent Case $\mathrm{Y}$ successfully argues that his situation is materially different than that of the plaintiff in unfavorable precedential Case X, the court in Case Y need not reach a result identical to that of Case $X$; that is, the plaintiff in Case $\mathrm{Y}$ will not be bound by the rule of Case $\mathrm{X}$. In contrast, if the defendant in Case $\mathrm{Y}$ convinces the court that she and the plaintiff are situated materially similarly to the parties to Case $\mathrm{X}$, the court will follow the rule of Case $\mathrm{X}$, binding the parties to the same result reached in Case $\mathrm{Y}$. Thus the method of stare decisis ensures that an adjudicatively created rule will bind litigants only to the extent that they are situated similarly to the parties who participated in creating the mule.

In other words, the common law method ensures interest representation. 189 A litigant is not bound by a court-made rule unless his situation is similar in material ways to that of a party that participated in creating the rule. And the theory of interest representation holds that similarly situated parties will have relevant interests in common. The plaintiff in Case $\mathrm{X}$ asserting a novel theory of tort recovery will have the same interest in employing that theory successfully that a later plaintiff in Case $\mathrm{Y}$, suffering the same injury under similar conditions, would have. The plaintiff in Case $\mathrm{X}$, that is, serves as an interest representative of the plaintiff in Case $\mathrm{Y}$. In acting on her own behalf, the plaintiff in Case $X$ is also necessarily acting on behalf of the similarly situated plaintiff in Case Y.

Note that the common law method as a mechanism of interest representation satisfies both the proceduralist and the functionalist approaches to lawmaking legitimacy. From a proceduralist perspective, the plaintiff in later Case $\mathrm{Y}$ (call him $\mathrm{P}_{\mathrm{Y}}$ ) can rely on the likelihood that the original plaintiff in Case $X\left(P_{X}\right)$ acted in $P_{Y}$ 's best interests in pressing the theory, because $\mathrm{P}_{\mathrm{X}}$ 's best interests and $\mathrm{P}_{\mathrm{Y}}$ 's best interests coincide. ${ }^{190}$

189. As we shall see, this statement probably needs to be qualified in a couple of respects. First, if one believes that mere similarity of interests does not assure adequate representation, then one might not be confident that the common law method assures adequate representation. I discuss this issue in more detail infra Part II.C. Second, there are certain contexts in which the common law method cannot really operate in the archetypal way I have described here; for instance, when a court strikes down a statute as unconstitutional, parties whose interests were not represented by parties to the case may be affected. I discuss three examples of such circumstances infra Part IV.

190. As Robert Bone has written of res judicata, a doctrine with many similarities to stare decisis, the theory of interest representation "supposes that a party adequately represents an absentee when that party shares the same or similar substantive litigation goals ('interests') and vigorously litigates the suit. Under these circumstances, the party's commitment to her own self interest indirectly furthers the interests of the nonparty." Bone, supra note 32 , at 203. I would add that the existence of a strong self-interest in the outcome of the lawsuit usually serves to ensure that the participating party will "vigorously 
Likewise, from a functionalist perspective, society can expect that the rule produced in Case $\mathrm{X}$ is the best possible rule that could have been produced, since it was the product of reasoned argument between a plaintiff and a defendant who can be seen, respectively, to represent the interests of every similarly situated plaintiff and defendant out there.

This aspect of the common law method-its automatic implementation of interest representation, and thus of a measure of democratic legitimacy-appears to have escaped almost unnoticed in scholarly discussion of adjudicative lawmaking and analogical reasoning. ${ }^{191}$ But its implications are quite important. It means that adjudicative lawmaking is closely comparable in material ways to parliamentary lawmaking. As with statutes enacted by democratically elected legislatures, those bound by courtmade rules can be said to have participated in the creation of those rules through interest representatives. The common law method thus guarantees that adjudicative rulemaking will have some of the same kind of democratic legitimacy that parliamentary legislation possesses.

3. Interest Representation, Electoral Selection, and Legitimacy. - Of course, parliamentary legislators are selected by a method of free and open elections, while litigants in precedential cases usually are selected by sheer happenstance. For this reason the sort of representation produced by the common law method can be seen as a second-best alternative to electoral representation. The common law method might not generate as much democratic legitimacy as a process of representative democracy generates. But this gap in legitimacy between adjudicative and parliamentary lawmaking is not as wide as it might first appear.

litigate[ ] the suit." See my discussion of justiciability doctrines infra Part IV.C for an exploration of how the lack of a strong selfinterest in the outcome might affect adjudication as representation.

Stephen Yeazell has explored the concept of interest representation in the context of class action lawsuits, another subject with many similarities to stare decisis. Professor Yeazell notes that in class actions, "[i]nterest provides the substitute for individual initiative and consent; the class action justifies action that legally binds another without his consent by pointing out that his interest is represented in a situation in which it is inconceivable that he would not wish his interest to be so pursued." Stephen C. Yeazell, From Medieval Group Litigation to the Modern Class Action 15 (1987); see also id. at 197-212 (discussing development of idea of interest representation in class action context).

191. The salient recent exception is the work of Lea Brilmayer, who in several articles has discussed the representative function of stare decisis in the context of judicial review, arguing that justiciability doctrines must be construed restrictively in order to ensure that plaintiffs challenging statutes in court will adequately represent the interests of nonlitigants and future plaintiffs who will be affected by the court's ruling. See Brilmayer, supra note 176; Lea Brilmayer, The Jurisprudence of Article III: Perspectives on the "Case or Controversy" Requirement, 93 Harv. L. Rev. 297 (1979). I will discuss Professor Brilmayer's important insights in more depth during my application in Part IV.C below of the idea of adjudication as representation to the issue of justiciability. Edward Levi, in his germinal work An Introduction to Legal Reasoning, also hints at a theory of adjudication as representation when he asserts that the process of participatory adjudication "protects the parties and the community by making sure that the competing analogies are before the court." Levi, supra note 11 , at 4. 
a. The Common Law Method and True Interest Representatives. - For one thing, the common law method is a more perfect system of selecting true interest representatives than elections could ever be: By definition, it applies rules only to those who are in fact similar to their representatives in precisely those ways that are relevant with respect to the rule, that is, precisely along the appropriate axis of interest. In contrast, people voting in elections-even assuming they can accurately identify points of similarity between themselves and the candidates-are unlikely always to focus on exactly those similarities that matter to the legislation a candidate will be enacting; and in any event, no elected representative ever can be situated similarly to each of her constituents in every important respect.

As such, the common law method improves on the interest representation mechanism of an electoral system in several related respects. It requires the court to focus on specific points of similarity and difference between the situations of the parties to the precedential and subsequent cases, not on general similarities in status or description between the parties. It is concerned only with those points of similarity and difference that are demonstrably relevant to the rule by which a litigant might be bound. And it ensures that representatives will be similar to their constituents in every way relevant to the rules by which the constituent might be bound; a litigant will find himself-represented by entirely different representatives with respect to entirely different rules. Thus the common law method assures that a party will not have been represented by a prior litigant who is similar to her in just any old way; it sees to it that the similarities between representative and constituent are specifically material to every rule by which the constituent will be bound.

It would appear, then, that the common law method accomplishes interest representation better than the electoral process does. Subsequent litigants may not have direct coercive power over the representatives who produce court-made rules on their behalf, but there is a solid basis for assuming that those representatives will act roughly how the subsequent litigants would act in their shoes. If a factual basis for this assumption is absent, the common law method ensures that the rule in question will not be binding. From the perspective of democratic legitimacy, therefore, the absence of direct coercive power over prior litigants does not trouble us as much as the absence of such power over elected representatives would, because we have good reason to believe that the mechanism of interest representation will operate better in adjudication than it does in parliamentary legislation. Stronger interest representation compensates, to some degree at least, for the lack of electoral coercion.

b. "Election" of Representatives Through Participatory Adjudication. There is a second reason why the interest representation brought about by the common law method is not so poor an alternative to electoral control as we might thimk. Here we return to the process of participatory adjudication. Facts and legal arguments do not magically appear before a 
judge deciding a case; they are framed, produced, and managed by the parties themselves. Thus precisely which precedents-precisely which court-made rules-will be determinative of a case, and precisely how they will be determinative, depend to a significant degree on how the parties choose to litigate the case. If the plaintiff succeeds in strategically downplaying certain facts, a harmful precedent in which similar facts played a prominent role might go unnoticed. If the defendant chooses to advance one legal theory and rejects another, a whole line of precedents might become irrelevant. And even assuming all arguably material facts and precedents find their way before the court, the acumen and force of the reasoned argnments of the respective parties will determine which precedents are followed, which are ignored, which are interpreted narrowly and which are analogized expansively.

In short, it is not stretching things too far to say that the parties have some ability to choose-to "elect"- their representatives by bringing certain precedents to the fore and relegating others to the background. Seen this way, a court case becomes something like a hotly contested election. Partisans of each candidate present reasoned arguments to the ultimate decisionmaker-in the court case, the judge; in an election, their fellow citizens-explaining why their candidate should be chosen to govern. The litigant's "candidates" are simply opposing theories of the case with their respective supporting readings of precedent. In an election the winning candidate can be said to have been "chosen" even by those who voted against her, because all had an equal opportunity to present their best arguments in a fair selection process. Similarly, in a court case the winning theory, and the precedents supporting it, can be said to have been "chosen" even by the losing litigant, who similarly had a fair opportunity to make his best case. The losing litigant cannot complain that the losing litigant in a precedential case deemed to be controlling was not in fact an adequate representative of his interests, because he had every chance to convince the court not to rely on that precedent. The other side's arguments simply were better.

This point, of course, should not be carried too far. Picking precedents is not exactly like electing legislators. For one thing, the field of relevant precedential cases sometimes will be relatively well-defined and obvious; in such circumstances, most of the work of the litigants and their attorneys will consist not of choosing which precedents to rely upon, but of deciding how to analogize or distinguish the obviously relevant authorities. This does not look much like the simpler process of choosing among candidates $\mathrm{A}, \mathrm{B}$, and $\mathrm{C}$ in which the voter engages.

Even the process of deciding what to do with a precedent already before the court, however, is a participatory process, a process allowing the litigant to attempt meaningfully to shape the decision that will apply to her. As a medium of true participation, this process, which requires the litigant and her attorney to manage constructively the progress of the case and to make myriad subtle choices of order and method of proof, 
argument technique, emphasis, and the like, may be even more valuable than the somewhat mechanical act of flipping one or the other lever in a voting booth. ${ }^{192}$ And it is no objection to the portrayal of participatory adjudication as a kind of electoral process to say that the diversity and substance of the "representatives" (that is, the precedents) available to any litigant will be outside her control. The same is true of democratic elections, in which the typical voter is powerless to change either the field of candidates with which she is presented or the substantive views of those candidates.

Another way in which participatory adjudication is perhaps an imperfect substitute for the electoral process is the inability of litigants to change the decisions that constrain them by electing new legislators at the next opportunity. This imperfection too, though, is not as glaring as it may at first seem. A subsequent litigant can attempt to "change" unfavorable precedents by presenting reasoned arguments why those precedents should not apply to her. And it is not clear that even litigants who lose are harmed to a significantly greater degree, or in a significantly different way, than citizens whose candidates lose elections or whose preferred legislation does not pass. Precedents can be overruled just as legislators and statutes can be changed. We would like both kinds of events to occur only through a process of reasoned argument demonstrating that an initial decision was wrong, or that things have changed so much since then that the decision is no longer valid. Such arguments are open to the litigant as well as to the legislative constituent or the legislator herself. ${ }^{193}$

While participatory adjudication is not a mirror image of the electoral process, then, it still resembles that process in important ways. Like the electoral process, it enables and bolsters interest representation through a process of choosing representatives that is essentially par-

192. I do not mean to downplay the role of attorneys in this participatory process. Typically it will be the attorneys for the litigants, not the litigants themselves, who are making most of these decisions. But compare participatory adjudication to its alternative, adjudication by judicial fiat. Participatory adjudication places the ultimate control of these kinds of litigation decisions with the litigants themselves: They can choose lawyers that they think will make these decisions correctly, they can oversee the general (and sometimes even the specific) activities of the attorney during the litigation, and they can fire and replace attorneys whom they think are not performing adequately. The litigants can even represent themselves if they choose. Adjudication by judicial fiat, on the other hand, would remove most or all of these kinds of decisions from the litigants' hands entirely.

193. Of course, a losing litigant cannot, after exhausting her appeals, change the result of the specific case she has lost. But neither can a "losing" citizen reverse the effects he has suffered from an unfavorable statute merely by voting in the next election for a representative who will replace the law. The point is illustrated by imagining a court case in which the application of a statute is at issue. The losing litigant in such a case, who has been harmed both by an unfavorable court decision and by an unfavorable piece of legislation, is powerless to reverse that particular harm (i.e., change the result of that specific case) by any means-adjudicative or legislative. The most she can hope for is that the statute (or its judicial interpretation) will change in the future so that any similar case in which she is involved will be decided the other way. 
ticipatory. This is not to deny the ultimate authority of the judge, who occupies a decisionmaking role without a true analog in the electoral and parliamentary decisionmaking processes. No independent arbiter akin to the judge decides between alternative political candidates in elections or between alternative statutory provisions in the legislature, it is true; there the people rule. But this is not to say that parliamentary lawmaking simply is democratic while adjudicative lawmaking simply is not. It is to say only that parliamentary lawmaking is, or can be, finally more democratic than its adjudicative counterpart. We might not believe that participatory adjudication imbues adjudicative lawmaking with quite as much democratic legitimacy as parliamentary lawmaking posesses, but we must recognize that a meaningful degree of that kind of legitimacy is nonetheless present in it.

4. Representation of Conforming Nonlitigants. - So the effect of the common law method is to bind litigants only to those rules that can be said to have been produced through the participation of a true interest representative. In this way, the peculiarities of the coinmon law method extend the legitimate authority of a court decision from the parties immediately before the court to subsequent litigants whose cases will be controlled or affected by that decision, in much the same way that popular elections extend the participatory legitimacy of direct democracy to laws made by representative legislatures. But what of the potential binding effect of a court-produced rule on persons who never make it into court? What about those who conform their conduct to an adjudicatively created rule out of fear of the legal consequences they may suffer if they do not?

Here the argument for interest representation of similarly situated litigants becomes, in most cases, an a fortiori argument for interest representation of conforming nonlitigants. Nonlitigants who conform to a court-created rule imagine themselves to be litigants who will be bound by that rule. They adjust their behavior out of a belief that, were their behavior to be tested in court, their situation would be found similar to that of the party whose behavior was chastised or rewarded in a precedential case. Such conforming nonlitigants are not in reality bound by a precedential court decision; they are only predicting that they will be bound by that decision. Thus their resulting adjustment in behavior has an element of voluntariness to it, and is certainly no more troubling than the coercion of someone actually held by a court to be bound by a courtmade rule. Indeed, to the extent that such persons have advance warning of the potential applicability of a rule to their conduct, they can be said to choose their representatives (in the form of the precedents that will bind them) to a degree that litigants hauled unsuspectingly into court cannot. They have the opportunity both to conform their conduct to that required of similarly situated parties in decided cases, and to begin preemptively planning their arguments about the extent to which they should in fact be bound. 
There may be some kinds of cases in which this a fortiori argument becomes problematic. Suppose, for instance, that a manufacturer loses a products liability case. The result of the case may cause that manufacturer, and perhaps other manufacturers, to modify their conduct by selling the product (or similar products) in a less dangerous but more expensive form, or even by withdrawing the product from the market altogether. If only the manufacturers will be affected by their own conduct modification, we would not be concerned from the perspective of interest representation. But others will be affected too: consumers who want to purchase the product, and merchants who want to sell it. They will be forced to buy or sell the product at a higher price now, or will be prevented from buying or selling it at all. And we cannot say that the interests of these consumers and merchants were adequately represented by the plaintiff in the germinal litigation, because the plaintiff's interest clearly was to force the manufacturer to alter its conduct in this way (or, rather, to pay for not having altered its conduct in this way).

In this kind of case, interest representation seems not to work very well. Does this threaten our general view of the legitimacy of adjudicative rulemaking? The answer is threefold. First, although the existence of this kind of case reduces the extent to which we can claim adjudicative rulemaking is democratically legitimate, it does not eliminate our ability to make this claim. Many, probably most, court cases will not present this kind of representational problem, at least not in the degree that our products liability example presents it. And even in cases presenting such a problem, our evaluation of legitimacy must (again) be comparative, not absolute; we must compare the degree of legitimacy produced by a system of participatory adjudication and interest representation, imperfect though that system may be, with the degree of legitimacy that would be produced by a system of adjudication by judicial fiat. We must ask whether the interests of absent consumers and merchants are more likely to be represented by a system in which opposing litigants present proofs and reasoned arguments in favor of a certain result than by a system in which a judge decrees the result without the benefit of this participatory process. If our answer, as I suspect it may be, is that representation is better achieved through a participatory than through a dictatorial decisionmaking scheme, then cases like our products liability hypothetical are not so lacking in democratic legitimacy as we may initially fear.

This point leads nicely to a second response to such cases, which is that the interests of absent, dissimilarly situated parties may not be so unrepresented in them as we might imagine. It is true that the plaintiff in our hypothetical products liability case does not represent the interests of absent consumers and merchants who are willing to sacrifice safety for price and availability. But the plaintiff probably does represent the interests of consumers (and some merchants) who, like the plaintiff, value safety over price and availability - who are willing to have unsafe products made safer at greater cost or even removed from the market altogether. 
It is not clear that this group of nonlitigants will be less numerous than their more risk-prone, price-sensitive counterparts. And, perhaps more importantly, what of the manufacturer defendant in the case: Whose interests does it represent? Its own, certainly, and those of similarly situated manufacturers; but it also represents, at least to some degree, the interests of others who want the product to remain on the market at its current price, mcluding some consumers and merchants. The interest correlation here is unlikely to be perfect: The manufacturer, for instance, may not have as great an interest in defending a single product of its diversified product line as a merchant whose sole business is selling that product would have. But the point is that there is unlikely to be a significant group of nonlitigants whose interests in the result of a case like this are entirely unrepresented in the adjudicative process. Put simply, a nonlitigant consumer with an interest in the outcome of a products liability case either favors liability or opposes it. If the former, her interests are largely (if not perfectly) in step with the plaintiff's; if the latter, her interests are largely (if not perfectly) in step with the defendant's.

A final response to this kind of case is that to the extent the interests of the litigants do not perfectly coincide with those of affected nonlitigants, there may be remedies that can be implemented in the adjudicative process itself. I will discuss some possible remedies below when I consider another kind of case that often involves a significant number of affected nonlitigants: constitutional cases. ${ }^{194}$ One such remedy with particular application in the products liability context might be allowing affected groups who are not original parties to the case-consumer groups, for instance, and merchants' and perhaps manufacturers' trade associations-to intervene in the proceedings. Doing so would increase the likelihood that the interests of nonlitigants who are affected when a court decision significantly alters the status quo will be represented in the decisionmaking process.

\section{Adjudication As Representation: Three Necessary Conditions}

The concept of representation ... is a continuing tension between ideal and achievement.

\section{Hanna Pitkin 195}

We have seen now how the conjunction of two related phenomena can give adjudicative lawmaking some claim to democratic legitimacy. The first phenomenon is participatory adjudication-that process whereby court decisions are created in large part through the participation of the litigants before the court. Participation clothes the resulting decision with legitimate authority to bind the litigants, both from a proceduralist and from a functionalist perspective. 
The second phenomenon is interest representation through the common law method-that process whereby prior decisions are made binding on subsequent litigants only to the extent that the litigants in both cases are similarly situated in all material respects. Interest representation extends the legitimate authority of a court decision from the litigants immediately before the court to litigants (and conforming nonlitigants) subsequently affected by the decision through the force of precedent.

Operating together, these phenomena comprise a process I will call adjudication as representation. Adjudication as representation endows adjudicative lawmaking with a legitimacy akin to that present in democratic parliamentary lawmaking, a legitimacy derived both from the constructive participation of the governed and from the deliberative quality of the substantive decisions produced. This legitimacy thus springs from a separate source entirely than the necessity of filling gaps in legislative pronouncements or of checking the occasional excesses of majority rule to which those seeking to justify adjudicative lawmaking usually appeal.

But I have been painting a rose-colored picture of the adjudicative process. The activities of courts do not always fit this description quite so neatly; sometimes they fall quite short of it indeed. In Part IV we will look a bit more closely at some of those instances. Here, though, let me sketch the pattern that we will use in dissecting those cases, and in thinking about adjudication as representation for the remainder of this Article. I will do so by describing the two, or possibly three, general conditions that must exist for adjudication as representation to function properly (that is, legitimately).

The first general condition necessary for adjudication as representation is that the binding (i.e., precedential) decision actually be produced to a significant degree by the litigants. This condition is more or less a restatement of the features thought necessary by Fuller in order for adjudication in its core sense to exist: the parties must be allowed to take the lead in shaping the litigation through the presentation of proofs and reasoned arguments, ${ }^{196}$ and the court's decision must (in Professor Eisenberg's paraphrase) actually "proceed from and be congruent with [the parties'] proofs and arguments." 197 Excessive intervention by the court in the proof-taking or argument-making processes, or failure by the court to conform its decision relatively closely to the alternatives offered by the parties, threatens adjudication as representation by attenuating the connection between the litigants' conduct and the ultimate outcome.

The second necessary condition is that the precedential decision bind only those future parties who are similarly situated to the original litigants in every material way. This is simply another way of saying that subsequent courts must apply stare decisis correctly. Precedents must not be stretched be- 
yond their reasonable bounds to encompass materially dissimilar fact patterns; analogies must not be drawn based on insignificant factual similarities between the precedential and the subsequent case; meaningful differences between cases must not be ignored. Where parties are deemed bound by decisions rendered under materially different circumstances, the coincidence between the interests of the precedent-setting litigants and those of the subsequent parties is lost, and the representative legitimacy of the binding is compromised.

It is worth remembering here what we hinted at previously:198 A properly functioning mechanism of participatory adjudication in a subsequent case may to a certain degree remedy, or at least excuse, a breakdown of interest representation (i.e., an incorrect application of stare decisis) in that case. We should not forget that, ideally at least, the litigants in subsequent cases have as much control over the decisions of those cases as the litigants in a precedential case had over the decision in theirs. To the extent, then, that a subsequent court enlarges the precedential force of a case beyond its natural reach, the arguments of the parties to the later case themselves might be to blame. In other words, while the decision in such a subsequent case loses its legitimacy as an application of the decision in the precedential case, it may well have gained new legitimacy with respect to the parties it binds as a product of their own litigative efforts.

Argnably, there is a third general condition that is necessary in order for adjudication as representation to function correctly: that the conduct of the parties in litigating the precedential case meet a threshold standard of adequacy. If this condition applies, a subsequent litigant is not legitimately bound by a precedent unless her counterpart in the precedential case pressed his claims or defenses with a reasonable level of skill and enthusiasm; the precedent-setting litigant's failure, for instance, to present a key piece of evidence or to articulate the strongest legal arguments might prejudice similarly situated parties to a degree that would vitiate the legitimacy of binding them.

In many or most circumstances, this supposed third condition will be superfluous in light of the second condition identified above. A subsequent litigant who demonstrates that a party to a potentially precedential case failed to present key evidence or to make the best available argument thereby distinguishes her situation from the situation of the prior litigant. She tells the court that because she has presented material evidence that the prior litigant did not present, or because she has made a valid argument that the prior litigant did not make, she is situated differently from the prior litigant and should not be bound by the rule of that case. We would expect the court to credit this line of reasoning and recognize that it is not bound to reach the same decision in the subsequent case. Indeed, the later litigant's mere act of presenting different evi- 
dence or making different or stronger arguments, whether or not the previous litigant's failure to do so is recognized, might be sufficient to convince the subsequent court to discount or disregard the precedent. With respect to most defects in representation, then, the proper operation of stare decisis should eliminate the problem.

But there may be situations in which the correct application of stare decisis cannot remedy inadequate representation by precedent-setting parties. Defects in representation in the precedential case may be subtle and hidden from the view of later litigants and courts, such as where a prior litigant has presented all the relevant evidence and made all the appropriate arguments but has done so in an ineffective, unpersuasive way. Or the nature of the precedential decision itself might not admit of distinctions based on differing arguments or somewhat divergent facts, such as a decision broadly interpreting a statutory provision or invalidating a statute on constitutional grounds. ${ }^{199}$ In these kinds of circuinstances, the impairment of our third general condition of adequate representation may operate, absent correction, to compromise the legitimacy of an adjudicative decision as a binding rule.

One final comment about this third condition seems necessary here. Even assuming the third condition is not redundant of the second one, it could be argued that a representative's competence or lack thereof has no bearing on the legitimacy of the representation, and thus of the rules produced by means of that representation. Exhibit A in favor of this contention is the fact that we do not consider parliamentary legislation to be illegitimate merely because some or even all of the legislators who voted for it do not meet our ideal of competence. (Or perhaps we do; if so, this argument is thwarted before it begins.) Why should we place more stringent requirements on adjudicative representatives?

A possible answer is that unlike elected legislators, adjudicative representatives cannot be thrown out of office and replaced with more competent ones, who then can repeal and replace their predecessors' ill-conceived laws. Litigants bound by bad precedent must rely prinarily on the common law method to ensure that precedent-setting litigants have acted competently; and arguably, if a precedent binds despite having been incompetently litigated, this premise of interest representation is vitiated. The possibility of overruling-a possibility that itself may be open to the reasoned arguinents of the parties ${ }^{200}$-may temper this disadvantage, but it exists to some extent nonetheless. As such, actual adequacy of representation probably should be considered a necessary condition of adjudication as representation.

These, then, are the two, and probably three, necessary conditions of adjudication as representation. The next Part illustrates adjudication as

199. Such cases may also violate the second condition of adjudication as representation, as the discussion of constitutional cases below suggests. See infra Part IV.B.

200. See supra note 193 and accompanying text. 
representation in action in some paradigmatic cases-cases in which all three of these conditions exist.

\section{Adjudication As Representation in Action}

All theory, dear friend, is grey, but the golden tree of actual life springs ever green.

\section{Johann von Goethe 201}

How does adjudication as representation actually work in the real world? The answer is not only empirical; it also is largely anecdotal and thus difficult to examine. This holds true for all three conditions necessary for the process to function. The degree to which a court decision is responsive to the actual participation of the parties is hard to track because the only reportage of court cases that is regularly published and widely available - written judicial opinions-no longer routinely recounts the arguments of the parties and usually gives little or no indication of how the case was litigated in the trial court. This problem is exacerbated by the fact that most published opinions are those of appellate tribunals, not trial courts. These same factors make it even more difficult to assess the quality of advocacy engaged in by the litigants and their attorneys. In order to test for these conditions in a typical court case, one therefore must be on the lookout for bits and pieces in the reported opinions, remaining vigilant for, to borrow the title of a recently popular rock album, "hints, allegations, and things left unsaid."202

Testing for the accuracy of an adjudicative rule's binding effect can be just as difficult, for different reasons. A precedent is not likely to be applied squarely (that is, to virtually identical facts) in many published opinions. This is because "easy" cases-those where the precedent binds without much controversy-rarely make it to the written opinion stage. Often they never make it to court at all; parties either modify their everyday conduct to conform to the precedent, or they settle out of court those conflicts that clearly are governed by the precedent. If such cases do make it to court, they likely will be disposed of summarily and without a published opinion, on a motion to dismiss or for summary judgment. Even if they survive through trial they are not likely to be the subject of a written, reasoned decision. Only very infrequently will such cases be memorialized in a published appellate opinion.

So, since researchers often find themselves working only with the opinions of appellate courts, they have to make do with what they can find in them. Modern appellate opinions rarely give much of a sense of how (or how effectively) the parties have participated in the decision. Moreover, they tend rarely to simply apply a precedent to virtually identi-

201. Johann von Goethe, Faust pt. 1 (1808).

202. Collective Soul, Hints Allegations and Things Left Unsaid (Atlantic Records Corp. 1993). 
cal facts to reach an identical result; more often when appellate (as opposed to trial) courts say they are "applying" or "following" a precedent, they are in fact simply reaching the same result on arguably analogous but nonetheless quite distinct factual circumstances. This is not so much a question of misapplying a rule as it is of creating a new rule, and we may assess the legitimacy of that new rule itself by the degree to which it was created through effective litigant participation and by the extent to which it binds only those future litigants or conforming nonlitigants who are similarly situated.

This Part is an attempt to illustrate the basic operation of adjudication as representation by examining three series of actual cases. First I will trace the development of a common law rule (and the implications of its development for adjudication as representation) through a string of California tort cases. Then I will discuss briefly how adjudication as representation inight translate from the common law to two other inodes of adjudicative decision: those interpreting and applying statutes and those reviewing statutes for consistency with constitutional provisions. I will work only with reported appellate opinions, so my methodology might suffer to a certain extent from the weaknesses described above. But I hope to have chosen cases in which such potential weaknesses can be assumed away, cases in which it is reasonable to assume that adjudication as representation has worked as it should. If, by the end of this Part, the reader has a fairly good picture of what adjudication as representation can look like in these three paradigmatic kinds of cases, I will have achieved here what I hope to achieve.

\section{A. Adjudication As Representation in a String of Common Law Cases}

That the courts should allow recovery to a inother who suffers emotional trauma and physical injury from witnessing the infliction of death or injury to her child for which the tort-feasor is liable in negligence would appear to be a compelling proposition.

... In the instant case, the presence of all the above factors indicates the plaintiff has alleged a sufficient prima facie case.

Dillon v. Legg ${ }^{203}$

Plaintiffs ... contend that they have stated a cause of action for negligent infliction of emotional distress under our decision in Dillon v. Legg . ...

Ochoa v. Superior Court 204

1. Creating a Common Law Rule: Dillon v. Legg. - In the well-known cominon law tort case Dillon v. Legg, the California Supreme Court al- 
lowed a plaintiff who had witnessed an auto accident in which a close relative was killed, but who was not herself in fear for her safety during the accident, to state a tort claim against the injuring party for negligent infliction of emotional distress. Dillon was the first American decision to reach such a result. ${ }^{205}$

The state supreme court's opinion in Dillon provides us with what appears to be a relatively complete account of the procedural and factual history of the case. The plaintiff in Dillon was Margery Dillon, the mother of a young girl who had been struck and killed by the defendant's car as the girl "lawfully crossed" a road at an intersection. ${ }^{206}$ Margery's complaint alleged that she had been "in close proximity to the ... collision and personally witnessed said collision."'207 Margery claimed to have "'sustained great emotional disturbance and shock and injury to her nervous system' which caused her great physical and mental pain and suffering" 208 as a result of witnessing the accident, and she sought damages from the defendant based on these injuries.

The defendant moved for judgment on the pleadings with respect to Margery's emotional distress claim. ${ }^{209}$ Citing existing case law, the defendant contended that Margery could not be allowed to recover for merely witnessing a tort unless she had "suffered emotional distress, fright or shock as a result of fear for [her] own safety."210 Because Margery had alleged that her emotional injuries resulted from the trauma of witnessing her child's death, not from any fear for her own safety, the defendant argued that she had alleged no legally cognizable injury. The trial court granted the defendant's motion and dismissed the case. Margery appealed to the state supreme court. ${ }^{211}$

Let us pause for a moment to note the degree to which the trial court's decision in Dillon appears to have been shaped by the activities of the litigants. (Recall that the degree to which the litigants themselves have shaped a decision is the degree to which the first necessary condition of adjudication as representation has been met. ${ }^{212}$ ) In Dillon, the facts and legal theories offered by the plaintiff in her complaint, and the

205. See Dillon, 441 P.2d at 914; Marc A. Franklin \& Robert L. Rabin, Cases and Materials on Tort Law and Alternatives 299-300 (4th ed. 1987).

206. Dillon, 441 P.2d at 914 . Another daughter who witnessed the accident also was a plaintiff. See id.

207. Id.

208. Id.

209. See id.

210. Id. at 914-15 (emphasis altered).

211. See id. at 915 .

212. See supra Part II.C. The degree to which the third (possibly) necessary condition of adjudication as representation-adequacy of representation, see id.-was met in Dillon is, of course, difficult to discern from the reported opinion, especially since the court does not explicitly rehearse the arguments of the parties in much detail. The most we can say for sure is that the losing party in Dillon, the defendant, appears to have identified the relevant precedents, which did not support liability, see Dillom, 441 P.2d at 914-15 (quoting defendant's memorandum supporting motion for judgment on the 
legal arguments made by the defendant in his motion, were entirely determinative of the legal issue decided by the court. Had Margery alleged that she had been in fear for her own safety during the accident, the defendant would have had no basis on which to bring his motion for judgment on the pleadings (or he would have had to bring the motion on a different theory entirely). Similarly, the defendant's decision to bring the motion, and to base it upon the theory that he used, forced the trial court to decide a certain issue in a certain procedural posture. Had the defendant, for instance, chosen to take discovery before seeking dismissal, it is possible that the facts elicited would have provided Margery with an alternative theory for the recovery of einotional damages, making the issue irrelevant; or the facts could have contradicted Margery's contention that she witnessed the accident, again mooting the question. And, had the defendant's attorney not uncovered the case law cited in his motion, Margery's emotional distress claim might have proceeded without legal challenge. In short, the parties presented the trial court with two mutually exclusive alternatives: dismiss the emotional distress claim on certain legal grounds, or retain it on the theory that those grounds do not apply. The trial court chose the former. Without the particular work done by the litigants and their counsel in Dillon, the trial court might have decided a different issue, or none at all.

Margery's decision to appeal the dismissal is, of course, also significant. She and her attorney probably did not go through the time and expense of an appeal to a state supreme court on a whim; they likely believed they had strong legal arguments in favor of allowing her claim to proceed, despite the countervailing case law. Thus the supreme court was presented not with a fait accompli, but with two reasoned and mutually exclusive theories of the case.

The supreme court in Dillon reversed the trial court's judgment on the pleadings. In doing so, the court rejected the defendant's contention that a witness to an accident must be allowed to recover for her own emotional injuries only if she feared for her own safety-only if, in the relevant terminology, she was in the "zone of danger."213 Instead the court adopted the plaintiff's theory of recovery. It is foreseeable to a tortfeasor, said the court, that even a plaintiff outside the zone of physical danger could suffer "bodily injury or sickness ... brought on by [the] emotional disturbance" of witnessing a severe injury to a loved one.214 This foreseeability gives rise to a duty of care on the part of a defendant with respect to bystanders. ${ }^{215}$ According to the court, the question whether this foreseeability actually exists "must necessarily be adjudicated only upon a

pleadings), and that the court spends most of the opinion considering and rejecting what appear to be the strongest policy arguments against liability. See id. at 916-25.

213. Dillon, 441 P.2d at 915.

214. Id. at 920 .

215. See id. 
case-by-case basis."216 But on the facts alleged in Dillon it clearly could be said to have existed, and the case therefore was allowed to proceed to trial.

Read as a rule that could be applied in factually similar future cases, the Dillon decision looks something like this: If a certain set of factual conditions is present-including a close relationship between an accident victim and the plaintiff, the plaintiff's contemporaneous presence at the accident scene, and the sensory perception of the accident by the plaintiff-then severe emotional injury to the plaintiff may be foreseeable and the plaintiff must be allowed to proceed with her tort claim. By allowing Margery's claim to proceed on these facts, the Dillon court bound future courts, by stare decisis, to reach the same result in cases where (at least roughly) the same set of facts is present. But as the Dillon court itself warned, its decision did not require future courts to reach a different result in the presence of dissimilar facts or, in other words, "in the absence or reduced weight of some of the ... factors" present in Dillon.217 Dillon left future courts free to "draw lines of demarcation upon facts more subtle than the compelling ones alleged in the complaint before [the Dillon court]."218

2. Reaching the Dillon Result on Similar Facts: Krouse v. Graham. For reasons already mentioned, the actual binding effects of the Dillon decision on subsequent litigants and conforming nonlitigants-and thus the extent to which the second necessary condition of adjudication as representation, the binding only of similarly situated parties, ${ }^{219}$ has been met-are difficult to ascertain. Some of these effects surely are hidden. Many accident defendants and their insurers probably settled claims after Dillon was handed down; other claims that would have been dismissed probably made it to trial and, eventually, to judgments that were not appealed with respect to the now-settled Dillon issue. In other words, much of the "binding" effect of Dillon undoubtedly took place sub rosa, through the process of people estimating their similarity to the parties in Dillon and settling their disputes or conducting their lawsuits accordingly. To the extent that this private activity accurately predicted the outcome of disputes should they progress to judgment, any coercion imposed by Dillon need not concern us: If similarly situated litigants are legitimately bound by the Dillon rule through adjudication as representation, a fortiori similarly situated nonlitigants are legitimately so bound. To the extent parties erred in their predictions of Dillon's binding effect, this need not

216. Id. The Dillon court also enumerated three general factual circumstances that "the courts will take into account" in determining foreseeability in bystander cases. Id. In this respect, Dillon established the sort of "multifactor test" that I critique later as threatening to adjudication as representation. See infra Part IV.A.3.b.

217. Dillon, 441 P.2d at 921.

218. Id.

219. See supra Part II.C. 
concern us either, not any more than a party's misreading of a statute makes us question the legitimacy of the statute itself. ${ }^{220}$

But of course the effects of the Dillon rule are not entirely concealed; it also has appeared in many subsequent reported decisions. In Krouse $v$. Graham, for example, the plaintiff sued to recover damages for emotional injury allegedly incurred when his wife was struck and killed by the defendant's car. ${ }^{221}$ There was 'a potentially material factual difference between Krouse and Dillon: Unlike the plaintiff in Dillon, the plaintiff in Krouse had not actually seen the defendant's car striking his wife. While the Krouse plaintiff sat in the driver's seat, his wife had been removing groceries from the back of their parked car. ${ }^{222}$ The defendant's vehicle had "approached the rear of the Krouse vehicle, straddled the curb, and struck [the wife] before colliding with the rear of the parked car." ${ }^{223}$ As the court described it:

[A]lthough [the plaintiff] did not see [his wife] struck by defendant's automobile, he fully perceived the fact that she had been so struck, for he knew her position an instant before the impact, observed defendant's vehicle approach her at a high speed on a collision course, and realized that defendant's car must have struck her. ${ }^{224}$

On this reasoning, the court held that the facts of Krouse were sufficiently analogous to those of Dillon to require the same result. ${ }^{225}$ Although Mr. Krouse did not actually see his wife hit by the defendant's car, his proximity to and sensory perception of the accident were so similar in material respects to those of the Dillon plaintiff that he "must be deemed a percipient witness" to the accident as the Dillon plaintiff had been.226 As such, he met the Dillon requirement of "sensory and contemporaneous observance of the accident."227

From the perspective of adjudication as representation, there are two ways to look at Krouse. The first is that the Krouse court straightforwardly applied the Dillon rule-that the situations of the parties in the two cases were in fact virtually identical in all material respects. If this was the case, Krouse was unquestionably legitimate in the representational sense, since the defendant who participated in the creation of the rule in Dillon and the defendant held bound by that rule in Krouse were identical in situa-

220. For important discussions of instances in which nonlitigants may be affected by a court decision without their interests having fully been represented before the court, see supra Part II.B.4 \& infra Part IV.

221. See 562 P.2d 1022 (Cal. 1977).

222. See id. at 1024.

223. Id.

224. Id. at 1031.

225. The actual issue in Krouse was whether certain jury instructions were proper. See id. at 1029-32.

226. Id. at 1031. 1968)).

227. Id. at 1030 (emphasis omitted) (quoting Dillon v. Legg, 441 P.2d 912, 920 (Cal. 
tion and thus in interest. The second necessary condition of adjudication as representation-the binding only of similarly situated future litigants-was satisfied.

The second way to look at Krouse is to assume that the facts of Krouse really were materially dissimilar to those of Dillon, but that the Krouse court nonetheless decided to reach the same result as in Dillon (potential liability). This view keys on the arguable difference between actually seeing an accident that injures a loved one and perceiving that accident through a combination of nonvisual senses. The argument for foreseeability in the latter sort of case might be thought weaker than the argument for foreseeability in the former. If so, the situation of the defendant in Dillon was dissimilar in this small but important way to the situation of the defendant in Krouse. On this view, the binding effects of Dillon extended only so far as its facts and those of Krouse were materially identical; beyond that point the parties in Krouse were free to argue for either possible result. If Krouse is seen in this way-as the implementation of an identical result to Dillon on dissimilar facts-then it is the same sort of case as Ochoa v. Superior Court, ${ }^{228}$ which I will discuss in Part III.A.4, below.

Note that the difference between these two alternative views of Krouse turns on whether that case can be described as materially "similar" or "dissimilar" to Dillon. If the former, it is a straightforward application of the Dillon rule, and if the latter, it is in essence the creation of a new rule above and beyond the binding effect of Dillon. Does this distinction make a difference from the perspective of adjudication as representation?

It should not make a difference. Remember that one component of adjudication as representation is a participatory process of adjudicationthe ability of the litigants to play a large role in determining their own fates by participating extensively in the formation of a decision. That process, we know, should operate in both precedential and subsequent cases. Whether we view the crucial issue in a subsequent case as what decision to reach after identifying materially dissimilar facts or as whether the facts are materially dissimilar at all, we must recall that the parties potentially bound by a precedential rule will play decisive roles in resolving either issue. If participatory adjudication functions properly, the extent to which a precedent binds the parties will, in a very real sense, be determined by the parties themselves-by their pleadings, proofs, and reasoned legal arguments. As such, even if Krouse bound dissimilar litigants to the Dillon result, it still can be seen as legitimate as long as the decision was largely a product of the litigants' own participation.

Assuming participatory adjudication functioned properly in Krouse, then, it does not matter whether the Krouse court's analogy to Dillon was objectively "correct" or "incorrect" (assuming it is even meaningful to assess the analogy in terms of "correctness"). If the analogy was correct, then interest representation operated properly in Krouse to bind the liti- 
gants to the Dillon result. If the analogy was incorrect, then participatory adjudication operated in Krouse to serve the same legitimizing function. What matters is simply that the parties to Krouse, through their participation in the decisionmaking process, had the opportunity themselves to determine the binding effect of Dillon, to make the bed in which they found themselves sleeping. ${ }^{229}$ In the words of Edward Levi, as long as "the competing analogies are before the court[,] [t]he rule which will be created arises out of a process in which if different things are to be treated as similar, at least the differences have been urged."230 Thus the result of Krouse, whether objectively "right" or objectively "wrong," can be seen as a legitimate manifestation of adjudication as representation.

Of course there is a certain element of fiction to my description here of adjudication as representation in Dillon and Krouse. The court in Krouse was indeed concerned with the legitimacy of subsuming that case under the Dillon rule, but it probably was not specifically occupied with the question whether the parties in Dillon were proper interest representatives of the parties in Krouse. It simply was concerned with the similarities and differences between the facts of the two cases. But to interpose this verity as an objection to the theory of adjudication as representation is to misunderstand the theory. That theory does not hold that interest representation in adjudication is a conscious process like it is in parliamentary legislation, in which the representatives are well aware that they are engaging in the process of representing and the constituents are equally aware that they are being represented. Rather, adjudication as representation assumes interest representation simply to be a functional feature of adjudication under certain conditions, conditions in which stare decisis is applied in the correct way. It does not matter that the participants-the litigants and the court-are unaware that what they are doing in distinguishing and analogizing case law is ensuring that only rules made by true interest representatives will be applied. What matters is that, through the process of distinguishing and analogizing, interest representation is in fact occurring. Knowledge and intent are irrelevant; that indeed is much of the point of a procedural theory of legitimacy.

3. Rejecting the Dillon Result on Dissimilar Facts: Deboe v. Horn. Deboe v. Horn was a California Court of Appeal case that, like Dillon and Krouse, involved alleged emotional distress resulting from a close rela-

229. Recall, of course, that the analogy between making arguments about precedent and "electing representatives" is not a perfect one. See supra Part II.B.3.b. But the point I am making here is not that litigants bave the unfettered ability to choose which precedents will bind them; clearly they do not in most cases. The point is that whether a court treats a precedent as materially similar and thus strictly binding, or rather as materially dissimilar and thus not binding, will turn in large part on the arguments and proofs presented by the litigants. Thus whether the Krouse court thought it was strictly bound to reach the Dillon result or, instead, believed it was not bound but decided to reach that result anyway is largely attributable to the activities of the parties in Krouse. This is the sense in which they have made the bed in which they are sleeping.

230 . Levi, supra note 11 , at 4 . 
tive's injury in an automobile accident.231 The plaintiff in Deboe was a wife whose husband had been struck and severely injured by the defendant's car. Unlike the mother in Dillon or the husband in Krouse, however, the plaintiff in Deboe was not actually present at the scene of the accident; instead she "was summoned to the emergency room at the hospital [after the accident], where she observed and was told her husband was totally paralyzed."232 Like the plaintiff in Dillon, Mrs. Deboe alleged that she had suffered "profound shock to her nervous system, mental suffering and emotional distress,"238 and sought damages from the defendant for her injuries.

The court of appeal affirmed the trial court's dismissal of the plaintiff's emotional distress claim. The court noted that Mrs. Deboe, unlike the plaintiff in Dillon, "was not a witness to the accident and was advised of its occurrence by others." 234 Her claim, then, and thus her situation and that of the defendant, was materially dissimilar to the plaintiff's claim in Dillon, and the Deboe court was not bound to reach the same result. The court refused to extend the Dillon result to these dissimilar facts and held that "no liability would exist as a matter of substantive law"285 in Deboe.

One initially might suppose the Deboe decision to have applied the Dillon rule to bind at both ends, as if it were a statute. The Deboe court acknowledged the binding force of Dillon and the fact that it would be compelled to reach the same result if its facts were materially similar to those of Dillon. But because it found an important dissimilarity in the facts of the two cases, the Deboe court refused to reach the same result the Dillon court had reached. This might be read as ascribing to Dillon both positive binding force (a requirement that a certain result obtain given the presence of certain facts) and negative binding force (a requirement that a different result obtain given the absence of some of those facts)precisely what most statutes do. ${ }^{236}$

Another way to read Deboe, however, and the reading most consistent with the operation of the common law method, is to understand that once the defendant in Deboe succeeded in convincing the court that the facts of that case were materially dissimilar to those of Dillon, the result of the case was, in a sense, thrown up for grabs. Not fully up for grabs, of course, because the Deboe court was not free to reach a decision that contradicted the result of Dillon; it was not free, for instance, to dismiss the case on the ground that emotional injury to bystanders outside the zone of danger was unforeseeable as a matter of law. But once a material dis-

231. See 94 Cal. Rptr. 77 (Ct. App. 1971).

232. Id. at 79 .

233. Id.

234. Id. at 223 (emphasis omitted).

235. Id. at 224.

236. Such a reading has some support in the Deboe opinion; but I will defer detailed discussion of this possibility until infra Part IV.A.3.b. 
tinction between the two cases was identified, the parties were free to argue that either possible result (potential liability or no potential liability) was consistent in this way with Dillon. The question became not so much a question of following an existing rule as a question of what new rule to create. The new rule that emerged from Deboe was the product of the same sort of participatory process in which the parties to Dillon had engaged, except that in Deboe the defendant's arguments carried the day.

From the perspective of adjudication as representation, the recognition by the Deboe court that the facts of that case were materially dissimilar to the facts of Dillon was the equivalent of a recognition that the litigants in Dillon were not true interest representatives of the litigants in Deboe. To the degree that the facts were the same-the presence in both cases of an auto accident, for example, and of emotional injury to a victim's relative as a result of the accident-Dillon controlled; the parties to Dillon resembled the parties to Deboe to that extent, and the Deboe litigants therefore had adequate interest-representatives and were not free to relitigate the entire issue of the foreseeability of emotional injury to close relatives of accident victims. This constraint was legitimate, remember, because the second condition of adjudication as representation-the binding only of similarly situated parties-was present.

And to the degree that the facts of Deboe were materially dissimilar to the facts of Dillon - the absence in Deboe of the victim's contemporaneous observation of the accident-the Dillon rule was not binding on the Deboe litigants. They were free to contest the import of this factual difference, that is, to determine through participatory adjudication what new "rule" would decide their case. As the result of Deboe indicates, the defendant won this contest. In another case the plaintiff might have won it. Either result would have been legitimate as long as the litigants participated meaningfully in creating the decision. ${ }^{237}$

Thus Deboe can be seen as an example of adjudication as representation functioning properly (because it is an example of stare decisis being properly applied). Nor should this conclusion change even if one believes that the Deboe court's factual distinction from Dillon was objectively incorrect: Recall that the parties to Deboe were in effect allowed to choose whether to be bound by the Dillon rule through the process of participatory adjudication, ${ }^{288}$ and thus any compromise of interest representation in that case was largely the choice of the parties themselves.

4. Reaching the Dillon Result on Dissimilar Facts: Ochoa v. Superior Court. - Faced with facts deemed materially dissimilar to those of Dillon, the court in Deboe declined to reach the same result. In Ochoa v. Superior

237. The extent to which the plaintiff in Deboe actually was permitted to argue that Dillon was not negatively binding is unclear from the opinion. The plaintiff did assert in a brief that her failure to witness the accident did "not preclude [her] . . . , as a matter of law, from asserting a claim for such damages." 16 Cal. App. 3d at 223.

238. See supra Part II.B.3.b; see also supra note 229 (explaining that litigants' arguments shape court's decision of which precedents to apply). 
Court, the court made the opposite choice.239 The plaintiffs in Ochoa were a mother and father whose 13-year-old son had died of an unspecified illness while in the custody of the Santa Clara County juvenile hall. While visiting their son in the hall, the plaintiffs observed that he was in severe physical discomfort, and they "experienced extreme mental and emotional distress upon seeing their son's illness and pain." ${ }^{40}$ The plaintiffs expressed concern to juvenile hall authorities, including a physician, that their son was not receiving adequate medical care. ${ }^{241}$ The authorities, however, refused to allow the boy to be treated by the Ochoas' family physician and apparently misdiagnosed the boy's condition, resulting in the boy's death (which was not actually witnessed by the parents). ${ }^{242}$ The Ochoas sued the county and various officials for, among other things, negligent infliction of emotional distress on a Dillon theory. The defendants moved to dismiss, and the trial court granted the dismissal. ${ }^{243}$

On appeal, the Ochoa court acknowledged that, unlike Dillon, the child's death in Ochoa was not "the result of a brief and sudden occurrence viewed contemporaneously by the plaintiff[s]."244 Thus there was some potential merit to the Ochoa defendants' argument that the parents' injury in that case was less foreseeable than the plaintiff's injury in Dillon. Nonetheless, the Ochoa court reversed the dismissal and allowed the plaintiffs to "state a cause of action under Dillon." 245 As in Dillon (and other cases following Dillon on analogous facts), the Ochoas were "aware of and observed conduct by the defendants which produced injury [to their] child" and were "able to perceive, and suffered shock, from the connection between defendants' conduct and [their] child's injury."246 Thus the Ochoas could potentially recover despite the absence of a "sudden occurrence"; the court was "satisfied that when there is observation of the defendant's conduct and the child's injury and contemporaneous awareness the defendant's conduct or lack thereof is causing harm to the child, recovery is permitted." 247

As in Deboe, the court in Ochoa thus acknowledged the presence of a material difference between the facts of its case and those of Dillon. The Ochoa court therefore recognized, as the Deboe court had, that it was not strictly bound to reach the same result that the Dillon court had

239. 703 P.2d I (Cal. 1985).

240. Id. at 3.

241. See id. at 3-4.

242. See id.

243. See id. at 4.

244. Id. at 6.

245. Id.

246. Id. at 8.

247. Id. 
reached. ${ }^{248}$ Unlike the court in Deboe, though, the court in Ochoa nonetheless reached the Dillon result, grounding its decision in the general analogies between Dillon and Ochoa, ${ }^{249}$ in the "flexib[le]" application of Dillon accomplished in a number of post-Dillon decisions, ${ }^{250}$ in the notion of reasonable foreseeability as it applied to the facts of Ochoa, ${ }^{251}$ and in the liberal policy of tort recovery which, according to the Ochoa court, "the [Dillon] cause of action was meant to further."252

Viewed through the lens of adjudication as representation, the Ochoa decision bound the litigants in that case to the rule of Dillon only to the extent that they were similarly situated to the Dillon parties and thus were adequately represented by those parties. As such, Ochoa satisfied the second necessary condition of adjudication as representation. To the degree that the similarity to Dillon, and thus interest representation, failed in Ochoa, the litigants were free to present reasoned arguments based in policy, broad analogy, and the like as to which of the two possible results the court should reach. ${ }^{253}$ Unlike in Deboe, the arguments of the plaintiffs in Ochoa were found by the court to be stronger than those of the defendants, and the plaintiffs' claim was reinstated. Thus, to the extent the result in Ochoa was based on materially different facts than those of Dillon, the Ochoa litigants participated in creating a new rule that then would bind litigants in similar future cases. With respect to those future cases, the first necessary condition of adjudication as representation was satisfied.

Again, it is unimportant for purposes of adjudication as representation whether the decision in Ochoa is viewed as based upon strict analogy with Dillon or as based upon reasoned arguments presented when strict analogy failed. As long as the litigants in Ochoa had a meaningful and effective opportunity to participate in the decision of that case, they can be said to have chosen their representatives by choosing whether (and to what extent) Dillon would bind them. Thus Dillon's binding effect on them, to the extent it existed, was as legitimate as if the facts of Ochoa had been identical to those of Dillon.

5. Summary. - The Dillon line of cases illustrates adjudication as representation in action in a common law context. If we make a few assumptions for the sake of demonstration-if we assume, that is, that participatory adjudication functioned properly in all of the cases we examined (and there is no reason to think it did not) - then each of the

248. Of course, the court deciding Ochoa was the California Supreme Court; as such, it was not in general strictly bound to follow its own decisions. But the Ochoa court nevertheless had no desire to be seen as contradicting Dillon.

249. See Ochoa, 703 P.2d at 7-9.

250. Id. at 7 .

251. See id. at 7-9.

252. Id. at 7 .

253. While the Ochoa court relied heavily on arguments of policy and broad analogy in deciding to broaden the Dillon rule, see id. at $6-9$, it is not clear from the opinion to what extent these arguments actually were presented by the plaintiff. 
parties to each of the cases implicating the Dillon rule was bound by Dillon only to the extent that his or her counterpart among the Dillon litigants was similarly situated to him or her in every material way. Where material similarity of situation was held to exist (as Krouse can be read to have held), the Dillon result obtained; where it was held not to exist (as in Deboe and Ochoa), the result was determined by the proofs and reasoned arguments of the parties. Dillon had binding effect, but it bound in only one direction. And even if we can quarrel with the results of particular cases-with the court's process of analogy or distinction in a given casewe cannot say that adjudication as representation necessarily failed in such cases, because the court's decisions in them were traceable in large measure to the activities of the litigants themselves. The parties were bound by a rule only to the extent that it was created by previous litigants whom the parties themselves chose as their representatives. In each case, then, the second necessary condition of adjudication as representation was satisfied.

The process of adjudication as representation in the common law therefore is a familiar and simple one; it is merely garden-variety litigation at work. But the implication of the process-the presence, through the process itself, of democratic legitimacy in the authority it wieldsmight strike a new chord. Recall the perceived problem that animates this Article: the assumption that courts act nondemocratically when they make decisions that bind present and future litigants (or conforming nonlitigants). Dillon and its progeny show us how this problem largely evaporates under the right conditions-how common law decisions can claim democratic legitimacy with respect to those affected by them. Let us review the process by which this can occur.

First and most simply, the decision in Dillon bound the litigants in that case in a democratically legitimate way because that decision was, to a siguificant extent, a product of the litigants' own participation in the decisionmaking process. Participation in decisionmaking, remember, is the key element of democratic legitimacy on both proceduralist and functionalist theories of democracy. ${ }^{254}$

Second, on one reading of Krouse, the Dillon decision legitimately bound the Krouse litigants to its result because the parties to Dillon, who were similarly situated in material ways to the litigants in Krouse, therefore served as interest representatives of those subsequent litigants. Interest representation, we have seen, is a mechanism used by democratic theory to legitimize the creation of authoritative rules by proxy. ${ }^{255}$

Third, to the extent that the Dillon decision bound the dissimilar litigants in Deboe and Ochoa-by establishing a baseline of tort liability to bystanders beyond which those courts could not retreat-that constraint was legitimate in the same way Dillon's constraint of the Krouse litigants 
was legitimate. Dillon bound them only insofar as they were similarly situated to, and thus their interests were represented by, the parties to Dillon. The Dillon decision did not bind the Deboe and Ochoa litigants to the extent that their interests were not represented by the parties to Dillon. In that nonbinding realm, the litigants in Deboe and Ochoa were free to participate in creating the ultimate decision through the presentation of proofs and reasoned arguments. As such, the results of those cases were democratically legitimate because the litigants themselves participated meaningfully in generating them.

Dillon and its progeny thus illustrate the operation of adjudication as representation in common law cases and the way in which democratic legitimacy can arise from it. But what of the other archetypal kinds of cases decided by courts-statutory and constitutional cases? Can adjudication as representation operate in them as well?

\section{B. Adjudication As Representation in Statutory and Constitutional Cases}

[T]he court [interpreting a statute] will search for the legislative intent. ... In building up this interpretation, the reference will be to the kind of examples that the words used, as commonly understood, would call to mind. Reasoning by example will then proceed from that point.

Edward Levi ${ }^{256}$

Restricting [constitutional] challenges to legislative action to the form of cases has the ... advantage of emphasizing the surrogate nature of the forum that courts are expected to provide.... If the challenge is unsuccessful, the precedential effect of the decision is . . . limited to other cases involving similar situations. A later challenger has freedom to reargue the statute's invalidity as applied to him to the extent that he has experienced the statute's impact in a different way.

Lea Brilmayer 257

The process of judicial construction and application of statutory and constitutional provisions often is thought to be essentially different from common law decisionmaking. Statutes and constitutions, as commands of a sovereign, seem to demand a process of making particular decisions within their purview that is concrete and unchanging, not flexible and accretive like the common law. ${ }^{258}$

256. Levi, supra note 11 , at 22-23.

257. Brilmayer, supra note 176 , at $816-17$ (citation omitted).

258. As David Strauss wrote in a recent article:

Conventionally we think of legal reasoning as divided into common law reasoning by precedent on the one hand, and the interpretation of authoritative texts on the other. Constitutional and statutory interpretation, while of course different in many respects, are viewed as forms of the latter and fundamentally different from the former. 
But, as some scholars persistently have noted, 259 the common law method often operates in statutory and constitutional adjudication just as it does in common law cases themselves. Statutes and constitutions are not self-interpreting; inevitably their language presents ambiguities, gaps that must be filled through the same case-by-case process of reasoning by analogy and distinction that operates in common law adjudication. 260 This process can generate the same conditions of legitimacy in statutory and constitutional cases that it can generate in common law cases: conditions of participatory adjudication and interest representation. When these conditions are present, statutory and constitutional adjudication becomes adjudication by representation; it takes on a siguificant measure of democratic legitimacy. Let us take a look at how adjudication as representation can work in statutory and then in constitutional adjudicative decisionmaking.

1. Statutory Interpretation Cases. - In The Legal Process, Hart and Sacks give us a good example of adjudication as representation at work in adjudicative statutory interpretation:261 the line of Sherman Act antitrust cases beginning with the 1922 Supreme Court decision in Federal Baseball Club of Baltimore, Inc. v. National League of Professional Baseball Clubs. ${ }^{262}$ Sections 1 and 2 of the Sherman Act, whose core language has remained unchanged since its enactment in 1890, prohibit, respectively, "contract[s], combination[s] . . or conspirac[ies], in restraint of trade or commerce among the several States" 263 and monopolies or attempted monopolies of "any part of the trade or commerce among the several States."264 In Federal Baseball, the plaintiff, a member of an upstart professional baseball league allegedly driven out of business by the defendants, two better-established leagues, brought a treble damages action under both sections of the Act. ${ }^{265}$ The court of appeals overturned a jury verdict in the plaintiff's favor on the ground that professional baseball was not "trade or commerce among the several States" within the meaning of

David A. Strauss, Common Law Constitutional Interpretation, 63 U. Chi. L. Rev. 877, 889 (1996) (citation omitted).

259. See, e.g., Henry M. Hart, Jr. \& Albert M. Sacks, The Legal Process: Basic Problems in the Making and Application of Law 1313-44 (William N. Eskridge, Jr. \& Philip P. Frickey eds., 1994); Levi, supra note 11, at 27-102; Sunstein, Legal Reasoning, supra note 177, at 79-90; Brilmayer, supra note 176; Brilmayer, supra note 191; Strauss, supra note 258.

260. See Cardozo, supra note 7 , at 14 (" $[\mathrm{C}]$ odes and statutes do not render the judge superfluous, nor his work perfunctory and mechanical. There are gaps to be filled. There are doubts and ambiguities to be cleared."); Levi, supra note 11, at 21-23 (discussing ambiguity in statutes); see also supra notes $9-11$ and accompanying text (describing Holmes' conception of the courts as gap-filling rulemakers).

261. See Hart \& Sacks, supra note 259, at 1313-36.

262. 259 U.S. 200 (1922).

263. 15 U.S.C. $\$ 1$ (1994).

264. 15 U.S.C. $\$ 2$ (1994).

265. See Federal Baseball, 259 U.S. at 207. 
the Act. ${ }^{266}$ In an opinion written by Justice Holmes, the Supreme Court affirmed the reversal:

The business is giving exhibitions of base ball, which are purely state affairs. It is true that . . competitions must be arranged between clubs from different cities and States. But [that] fact ... is not enough to change the character of the business. . . . [T] he transport [of players and equipment across state lines] is a mere incident, not the essential thimg. That to which it is incident, the exhibition, ... would not be called trade or commerce in the commonly accepted use of those words. As it is put by the defendants, personal effort, not related to production, is not a subject of commerce. That which in its consummation is not commerce does not become commerce among the States because the transportation that we have mentioned takes place. ${ }^{267}$

Thus the Court in Federal Baseball-explicitly drawing, it should be noted, upon the reasoning offered by the defendants ${ }^{268}$ - found the playing of baseball games, even for money and where travel across state lines was involved, not to be the sort of "trade or commerce among the several States" that Congress had in mind when it passed the Sherman Act. As an interpretation of the Act, Federal Baseball created a rule, to be sure; but, like a common law rule, its binding effect did not extend beyond the particular facts of the case. The Federal Baseball rule merely required that, in future cases, any business having the peculiar characteristics that professional baseball possessed in 1922-consisting, that is, primarily of local sporting exhibitions carried out by the "personal effort" of the players in a manner that "would not be called trade or commerce in the commonly accepted use of those words"-must be held to be outside the scope of the Sherman Act. ${ }^{269}$ Like a common law decision, Federal Baseball did not require that any cases bearing materially different facts be decided in a particular way. Such cases would have to be litigated on their own merits.

Almost exactly a year after the Federal Baseball decision was handed down, in Hart v. B.F. Keith Vaudeville Exchange, ${ }^{270}$ the Court arguably was faced with such a materially different case. Hart was another lawsuit under the Sherman Act, this time brought by a vaudeville agent who alleged that the defendants, other agents and theater owners, had conspired to exclude the plaintiff's clients from performance at "practically all the theatres in the United States and in Canada in which high class vaudeville entertainments are produced."271 The defendants argued that Federal Baseball was controlling-that, as with baseball in the previous case, "the dominant object of all the arrangements [of the defendants'

266. Id. at 208-09.

267. Id.

268. Compare the Court's paraphrase of the defendants' argument, see id. at 209, with the summary of that argument offered earlier in the opinion, see id. at 206-07.

269. Id. at 209.

270. 262 U.S. 271 (1923).

271. Id. at 272 . 
business] was the personal performance of the actors, all [interstate] transportation being merely incidental to that."272 The Supreme Court, again through Holmes, summarily rejected this argument:

On the other hand it is argued [by the plaintiff] that in the transportation of vaudeville acts the apparatus sometimes is more important than the performers and that the defendants' conduct is within the statute to that extent at least.

... [I] t may be that what in general is incidental, in some

instances may rise to a magnitude that requires it to be considered independently. ${ }^{273}$

In other words, vaudeville performances, at least on the allegations of the plaintiff's pleadings (for Hart was decided on a motion to dismiss), were materially dissimilar to baseball exhibitions; their "apparatus" and its transportation "sometimes [were] more important than the performers themselves," and thus the business of vaudeville was more likely than baseball to be the sort of "trade or commerce" envisioned by Congress when it passed the Act.

Whether or not the baseball-vaudeville distinction drawn by the Court makes much sense to us, Hart displays the common law method, and thus the process of adjudication as representation, at work in a statutory interpretation case. The central question of Hart was whether vaudeville acts were similar enough to baseball games to be covered by the same rule, that is, to require that the same result be reached in Hart that was reached in Federal Baseball. Responding to the proofs and arguments of the parties-indeed, expressly grounding its holding in the allegations made by the plaintiff in his complaint-the Court in Hart answered this question in the negative: It, and the litigants before it, were not bound to the result of Federal Baseball because vaudeville was dissimilar to baseball in certain material respects. Thus the parties in Hart were free to argue for any result consistent with the statute. ${ }^{274}$ Adjudication as representation had functioned properly: The Hart plaintiff had in effect convinced the Court that the plaintiff in Federal Baseball was not his adequate interest representative and that he therefore should not be bound by the result of that case.

The inpact of Federal Baseball did not die with Hart, however. Several subsequent decisions considered the holding of that case in various related contexts. In the 1953 case Toolson $v$. New York Yankees, Inc., the Court squarely applied Federal Baseball to uphold the dismissal of several Sherman Act civil actions brought against professional baseball teams. ${ }^{275}$

272. Id. at 273.

273. Id. at 273-74.

274. Indeed, on remand the defendants apparently succeeded in convincing the trial court that vaudeville performances, like baseball games, were entitled to exemption from the Act, thus gaining a later dismissal of the case; the court of appeals affirmed and the Supreme Court denied certiorari. See United States v. Shubert, 348 U.S. 222, 228 n.10 (1955).

275. See 346 U.S. $356,356-57$ (1953). 
As presented in the per curiam opinion, Toolson was a straightforward application of stare decisis to directly on-point facts: the business of baseball in 1953 was not materially different from the business of baseball in 1922 , and thus the situations of the two cases were indistinguishable. ${ }^{276}$

In United States $v$. Shuberit, a 1955 case with facts closely sinilar to those of Hart, the Court refused to apply Federal Baseball to grant a Sherman Act exeinption to the business of producing and booking "legitimate theatrical attractions" and operating theaters. 277 The Court distinguished Toolson as "a narrow application of the rule of stare decisis";278 if stare decisis were to be applied in Shubert, "Hart ... - -not Federal Baseball and Toolson-[is] the controlling decision[ ]."279

Finally, in United States v. International Boxing Club of New York, Inc., decided on the same day as Shubert, the Court refused to extend the Federal Baseball-Toolson exemption to the business of conducting professional boxing matches, which, "as described in the coinplaint," was of a sufficiently interstate nature to "constitute[ ] 'trade or commerce among the several States' within the meaning of the Sherman Act." 280 Justice Frankfurter vigorously dissented in International Boxing Club, declaring that "[i]t would baffle the subtlest ingenuity to find a single differentiating factor between other sporting exhibitions, whether boxing or football or tennis, and baseball" with respect to whether such activities amounted to "'trade or commerce.'"281

These decisions demonstrate simply that statutory interpretation cases, despite the presence of a supposedly authoritative text, frequently become exercises in analogical, case-by-case reasoning virtually indistinguishable from what takes place in the common law. As in common law adjudication, the question in statutory interpretation cases often is whether the fact pattern before the court so closely resembles a fact pattern found by a previous court to produce a certain effect (in statutory cases, the application of a statute in a certain way) that the subsequent court is required to prescribe the same effect (that is, to apply the statute in the same way). And where this common law process operates, adjudication as representation, for the reasons we have seen, operates as well. Litigants are able to participate in shaping the decisions that bind them, and they are bound by previous decisions only to the extent that those decisions were shaped by their interest representatives.

276. See id. Justice Burton's dissent in Toolson challenged this assumption, pointing to the extensively interstate nature of professional baseball at the time the case was decided, including the revenues it derived from radio and television broadcasts. See id. at 357-65 (Burton, J., dissenting).

277. 348 U.S. 222, 223 (1955).

278. Id. at 230 (emphasis omitted).

279. Id.

280. 348 U.S. 236,240 (1955).

281. Id. at 248 (Frankfurter, J., dissenting). 
2. Constitutional Cases. - The common law method also operates in constitutional cases, perhaps to an even greater extent than it does in statutory cases. ${ }^{282}$ An example is the line of decisions assessing First Amendment challenges to convictions under the Espionage Act of 1917 and similar statutes restricting subversive speech. The first of these cases, Schenck v. United States, 283 produced Holmes's famous "clear and present danger" test for the assessment of speech-restricting legislation. To the extent this formulation later took on a life of its own as a rule separate and independent of the facts and result of Schenck, it diverged from the coinmon law method and compromised the operation of adjudication as representation, but I will discuss that point in the next Part. ${ }^{284}$ For present purposes it is enough to note how cases following Schenck reasoned, in the common law fashion, by analogy and distinction to the facts of that case in reaching their own results.

In Schenck the Court was faced with the conviction, pursuant to the Espionage Act of 1917, of socialists who had distributed leaflets arguably encouraging draft resistance. The language of the leaflets was ambiguous to say the least; one side encouraged draftees not to "submit to intimidation," while the other side prompted them simply to "assert your opposition to the draft." 285 In order to determine whether the evidence was sufficient to sustain the convictions, the Court was required to consider the defendants' argument that the convictions restricted their freedom of speech and press in violation of the First Amendment. Writing for a unanimous Court, Holmes opined:

We admit that in many places and in ordinary times the defendants in saying all that was said in the circular would have been within their constitutional rights. But the character of every act depends upon the circumstances in.which it is done. The most stringent protection of free speech would not protect a man in falsely shouting fire in a theatre and causing a panic. ... The question in every case is whether the words used are used in such circumstances and are of such a nature as to create a clear and present danger that they will bring about the substantive evils that Congress has a right to prevent. It is a question of proximity and degree. ${ }^{286}$

Because the defendants' words in Schenck could be found to pose such a clear and present danger, the convictions were affirmed.

The Schenck decision was applied squarely to two subsequent cases involving similar convictions under the Espionage Act, Frohwerk v. United

282. See generally Strauss, supra note 258 , at 889 ("To whatever extent the contrast with the common law is true for statutes, it is not true of an eighteenth- and nineteenthcentury constitution."). For a significant category of exceptions to this statement, see my discussion of judicial review infra Part IV.B.

283. 249 U.S. 47 (1919).

284. See infra Part IV.A.3.a.

285. Schench, 249 U.S. at 51.

286. Id. at 52 (citations omitted). 
States $^{287}$ and Debs $v$. United States. ${ }^{288}$ In Frohwerk the defendant was a German sympathizer who, according to a jury, had published inflammatory newspaper articles with the intent of disrupting the draft; in Debs the defendant was a well-known socialist who had spoken against the draft. Both convictions were affirmed by a unanimous Court in opinions also written by Holmes. Holmes saw both cases as substantively indistinguishable from the recently decided Schenck, commenting in Frohwerk that "so far as the language of the [newspaper] articles goes there is not much to choose between expressions to be found in them and those before us in Schenck v. United States." 289 According to the Court, that is, the results of Frohwerk and Debs were dictated by the result of Schenck because the facts of the three cases were materially identical.

Then, in three subsequent Espionage Act cases following closely on the heels of Schenck, Frohwerk, and Debs-Abrams v. United States, ${ }^{290}$ Schaefer v. United States, ${ }^{291}$ and Pierce v. United States ${ }^{292}$-the unanimity of the Court was broken. All three cases produced affirmances of convictions under the Act for conduct arguably similar to that of the Schenck, Frohwerk, and Debs defendants. In all three, however, Holmes and Justice Brandeis published lengthy dissents, and in Schaefer Justice Clarke wrote a separate dissent as well. The lynchpin upon which the three cases turned was whether the conduct of which the defendants were accused rose to the level of the clear and present danger found to exist in Schenck, Frohwerk, and Debs-whether, that is, the defendants in Abrams, Schaefer, and Pierce were sufficiently similarly situated to the defendants in the prior cases to mandate the same result. Holmes and Brandeis thought not, focusing in each case on what they perceived to be a tenuous connection between the speech at issue and the sort of direct adverse consequences to the military effort threatened by the speech in Schenck. ${ }^{293}$

In Dennis v. United States, a 1951 case brought pursuant to the Smith Act, the Court considered how Schenck should apply to a case in which the defendants' activities seemed directed to the eventual overthrow of the government rather than the sort of imminent danger to order that the speech punished in Schenck and its progeny was thought to threaten. ${ }^{294}$ The defendants in Dennis were members of the American Communist Party who had been convicted of advocating, and organizing for the purpose of, "overthrowing or destroying [the] government [of] the United States by force or violence'" in a manner consistent with the revolutionary

287. 249 U.S. 204 (1919).

288. 249 U.S. 211 (1919).

289. Frohwerk, 249 U.S. at 207.

290. 250 U.S. 616 (1919).

291. 251 U.S. 466 (1920).

292. 252 U.S. 239 (1920).

293. See Pierce, 252 U.S. at 253-73 (Brandeis \& Holmes, J., dissenting); Schaefer, 251 U.S. at 482-95 (Brandeis \& Holmes, J., dissenting); Abrams, 250 U.S. at 624-31 (Holmes, J., dissenting).

294. See 341 U.S. 494 (1951). 
beliefs of the party. ${ }^{295}$ Writing for a plurality, Chief Justice Vinson tacitly acknowledged that the conduct at issue in Dennis did not bear the sort of immediate threat of violence and disorder that the conduct in Schenck had been held to display. The Court nonetheless affirmed the convictions on the ground that "the gravity of the 'evil,' discounted by its improbability, justifies such invasion of free speech as is necessary to avoid the danger."296 In doing so, the Dennis Court can be seen to have done roughly what the California Supreme Court did in the common law Ochoa case discussed in the previous Part: ${ }^{297}$ the Court first rejected the notion that Schenck was fully binding on the differently situated litigants of Dennis, but then determined, through the proofs and reasoned arguments of the parties in that case, that it should nevertheless reach the same result as that reached in Schenck.

Finally, in Brandenburg v. Ohio, the Court declined to reach the Schenck result on what it determined to be materially different facts. ${ }^{298}$ The defendant in Brandenburg was a Ku Klux Klan leader who had been convicted under the Ohio Criminal Syndicalism statute of "'advocat[ing] ... the duty, necessity, or propriety of crime, sabotage, violence, or unlawful methods of terrorism as a means of accomplishing industrial or political reform."'299 (One wonders precisely which "methods of terrorism" the Ohio legislature did not consider "unlawful.") The defendant had been captured on film burning a cross in the traditional KKKK regalia, accompanied by several companions carrying firearms; in another portion of the film the defendant gave a speech at a rally in which he exclaimed that "if our President, our Congress, our Supreme Court, continues to suppress the white, Caucasian race, it's possible that there might have to be some revengeance taken." 300 Citing the principle, gleaned from Schenck and other decisions (although Schenck itself was not actually mentioned in the Court's opinion), that the First Amendment allowed states to prohibit the advocacy of violence only "where such advocacy is directed to inciting or producing imminent lawless action and is likely to incite or produce such action" 301 but not where it amounted to "mere abstract teaching ... of the moral propriety or even moral necessity for a resort to force or violence," 302 the Court overturned the conviction. Here, as in the California common law decision in Deboe v. Horm, ${ }^{303}$ the

295. Id. at 496 (quoting section 2 of the Smith Act, 18 U.S.C. $\$ 10$ (1946)).

296. Id. at 510. This language was Learned Hand's interpretation of the Schenck phrase "clear and present danger," taken from his Second Circuit opinion in United States v. Dennis, 183 F.2d 201, 212 (2d Cir. 1950).

297. See supra Part III.A.4.

298. See 395 U.S. 444,445 (1969).

299. Id. at 444-45 (quoting the Ohio Criminal Syndicalism statute, Ohio Rev. Code Ann. § 2923.13).

300. Id. at $445-46$.

301. Id. at 447.

302. Id. at 448 (quoting Noto v. United States, 367 U.S. 290, 297-98 (1961)).

303. 94 Cal. Rptr. 77 (Ct. App. 1971); see supra Part III.A.3. 
Court can be seen to have rejected the binding force of Schenck and its progeny because of materially dissimilar facts between Brandenburg and those cases and to have decided, again through the proofs and arguments of the parties, to reach a different result than that of Schenck.

As in statutory interpretation cases, then, the common law method can operate in constitutional cases. When courts adhere to this common law mode in reviewing statutes for constitutionality, adjudication as representation works just as it does in the common law itself. Subsequent litigants are bound only so far as they are found to be similarly situated to the parties to the precedential case, and those subsequent litigants themselves are allowed to "choose" their representatives by arguing for or against the binding force of any particular decision. And although Schenck and its progeny were criminal cases, the common law process applies no less in civil challenges to statutes. ${ }^{304}$

All of this is not to say that statutory and constitutional adjudication do not differ in important ways from common law decisionmaking, or that adjudication as representation always functions flawlessly in statutory and constitutional cases. Neither claim would be true. Indeed, in the next Part we will look at some of the situations in which, from the perspective of adjudication as representation, such claims often ring all too hollow. But the foregoing discussion should at least have demonstrated just how adjudication as representation works through the cominon law method, and how the common law method (and, through it, adjudication as representation) can function in a variety of adjudicative contexts. It should, that is, have provided some paradigm cases of adjudication as representation in action. Now it is time to consider some implications of the theory of adjudication as representation as applied to several important current issues.

\section{The Theory of Adjudication As Representation: Some Topical ApPlications (and SOME Surprising IMPlications)}

It is therefore not the fault of the theory if it is of little practical use in such cases. The fault is that there is not enough theory ....

\section{Immanuel Kant ${ }^{305}$}

Believe it or not, many of the vexing issues in modern adjudication, studied though they are, suffer from the problem of not enough theory. Adjudication, especially adjudicative lawmaking, typically is seen as an irredeemably nondemocratic process. Where adjudication comes into tension with parliamentary lawmaking, the goal of adjudicative theory has been to reduce that tension to a minimum or, sometimes, to explain away

304. See, Brilmayer, supra note 176 , at 817 ; Brilmayer, supra note 191 , at $306-10$.

305. Kant, Theory and Practice, supra note 35, at 61 . 
the tension as illusory. ${ }^{306}$ That the results of this effort have been unsatisfactory should not surprise us when we consider what has been missing from adjudicative theory. The missing piece-at least, $a$ missing piecehas been an understanding of adjudication as representation, a recognition that adjudicative lawmaking can in fact be democratic under certain conditions. The goal of the theory of adjudication as representation is not to reconcile adjudicative with parliamentary lawmaking, but rather to define the conditions necessary for democratic legitimacy in adjudication and to suggest how they might be preserved. As such, that theory treats adjudicative lawmaking as only occasionally, not inherently, "deviant" from the democratic ideal. 307

In this Part, I will examme three current issues in adjudication from the perspective of adjudication as representation. The examination in each case will be somewhat tentative. Here I am more concerned with shedding some new light on these old questions than with dissecting them methodically, and I will be happy if I do no more than stimulate fresh discussion about them. Chekhov once wrote of Anna Karenina and Eugene Onegin that "not a single problem is solved, but they satisfy you completely just because all their problems are correctly presented."308 In a similar spirit, my goal here is not to solve these problems, but simply to present them in a new and helpful way.

The first suggestion I will make is that courts, in deciding cases (and, more to the point, in writing opinions), should not attempt to articulate general rules that will govern future cases. Stating general rules threatens the mechanism of interest representation, which works only if dissimilarly situated people are not bound by judicial decisions.

My second suggestion is that certain kinds of constitutional decisions are democratically illegitimate because they necessarily affect nonlitigants whose interests were not adequately represented in the adjudicative process. The theory of adjudication as representation implies some remedies for this illegitimacy, namely the exercise of decisional minimalism in judicial review and the participation in the litigation of a wider variety of interested parties and groups than is traditionally allowed.

306. See, e.g., John Hart Ely, Democracy and Distrust: A Theory of Judicial Review 77-104 (1980) (attempting to solve "counter-majoritarian difficulty" by justifying judicial review as a means of ensuring proper functioning of democratic processes); Barry Friedman, Dialogue and Judicial Review, 91 Mich. L. Rev. 577, 580 (1993) (declaring that counter-majoritarian difficulty "rests upon a descriptively inaccurate foundation," i.e., the counterposition of unaccountable courts with accountable branches of government, and articulating descriptive theory of "dialogue" among three governmental branches); Michelman, supra note 33, at 74 (stating theory of judicial review as "the modeling of active self-government that citizens find practically beyond reach").

307. See Alexander M. Bickel, The Least Dangerous Branch 18 (2d ed., Yale Univ. Press 1986) (" $[\mathrm{N}]$ othing . . . can alter the essential reality that judicial review is a deviant institution in the American democracy.").

308. Letter from Anton Chekhov to Alexei Suvorin (Oct. 27, 1888), in Selected Letters of Anton Chekhov 56, 57 (Lillian Hellman ed. \& Sidonie K. Lederer trans., 1955). 
My third suggestion is that justiciability doctrines should be strictly applied. The theory of adjudication as representation tells us that relaxation of justiciability requirements sometimes threatens interest representation by binding future litigants to decisions shaped by dissimilarly situated parties.

As we shall see, woven through each of these issues is a common thread: the threat to adjudication as representation that arises when the potential binding effects of a decision extend beyond its particular facts to parties whose situations are materially dissimilar to those before the deciding court. Because interest representation is compromised in such circumstances, democratic legitimacy is compromised too. The theory of adjudication as representation suggests at least that we pay attention to the existence and the nature of the legitimacy problems these kinds of cases present. ${ }^{309}$

\section{A. The Debate over Legal Rules}

Ordinary courts are reluctant to traffic in abstractions. Judges often proceed on a case-by-case basis; they are practitioners of the old, much-reviled, and indispensable art of casuistry.

\section{Cass Sunstein 310}

There is much debate nowadays about the place of "rules" in adjudication. ${ }^{311}$ The central question of the debate seems to be: Is it better for courts, in deciding cases, to attempt to lay down general rules intended to dictate the results of future cases, or is it better for courts to avoid this kind of broad rulemaking and confine themselves to saying only what is necessary to decide the particular case before them?

There are strong arguments on both sides. In defending the practice of making general rules, for instance, Justice Antonin Scalia points to the interlocking values of equality, efficiency, uniformity, predictability, and judicial restraint. ${ }^{312}$ On the other side of the question, Cass Sunstein attacks rules on the grounds that their inherent ambiguity "undermines the aspiration to rule-bound justice"313 and that they are prone to several varieties of harmful social consequences: over- and underinclusiveness, obsolescence, camouflage of bias and discretion, encouragement of tech-

309. There will, of course, be other topical implications of the theory of adjudication as representation - for statutory interpretation, procedural reform, and structural reform litigation, to name a few examples-that will have to remain outside my somewhat limited scope here.

310. Sunstein, Legal Reasoning, supra note 177, at viii.

311. See, e.g., Frederick Schauer, Playing by the Rules: A Philosophical Examination of Rule-Based Decision Making in Law and in Life (1991); Sunstein, Legal Reasoning, supra note 177, at 10-12, 101-47; Scalia, supra note 11; Kathleen M. Sullivan, The Supreme Court, 1991 Term-Foreword: The Justices of Rules and Standards, 106 Harv. L. Rev. 24 (1992).

312. See Scalia, supra note 11 , at $1178-80$.

313. Sunstein, Legal Reasoning, supra note 177, at 121-30. 
nical evasion through loopholes, inflexibility, and a weakening of "the equitable spirit." 114

Both sides of the debate measure the legitimacy of rules by their results. Justice Scalia thinks judicially articulated rules help order the world in a fair and productive way; Professor Sunstein disagrees. Neglected in the controversy is the issue of whether it is legitimate for courts to announce general rules at all, good results or no. As I contend here, the theory of adjudication as representation suggests that it usually is not. When courts articulate general rules that are intended (or that may be read by future courts) to govern future cases, the litigants in those future cases may be bound to a rule produced by dissimilarly situated parties. If so, interest representation, and thus the democratic legitimacy of the constraint, breaks down.

1. Rules Versus ... What? - The debate on rules is complicated by the uncertainty about precisely what the alternatives to rules might be. Rules often are contrasted with "standards" 315 - relatively vague requirements that leave open a number of reasonable possibilities of precisely what kind of conduct might comply with the requirement in any given circumstance:

A ban on "excessive" speeds on the highway is a standard; so is a requirement that pilots of airplanes be "competent," or that student behavior in the classroom be "reasonable." These might be compared with a 55-mile-per-hour speed limit, a ban on pilots who are over the age of seventy, or a requirement that students sit in assigned seats. ${ }^{316}$

Sometimes rules are compared with "principles"-general guides for conduct that, unlike rules or standards, must be weighed in any given case against other reasons for acting a certain way:

Consider some examples: tell the truth; keep your promises; do not hurt other people's feelings. These principles... a are not taken by themselves as decisive of moral issues. They bear on moral issues, but by themselves they do not resolve particular cases. Their content emerges from their applications. ${ }^{317}$

Rules also inight be compared to "factors"-specific factual considerations that must be taken into account when deciding how to decide a case. $^{318}$ For example, in an aspect of the Dillon $v$. Legg decision that I purposely treated only briefly above, ${ }^{319}$ the California Supreme Court suggested three "factors" that "courts will take into account" in determining whether bystander emotional injury is foreseeable:

314. Id. at 130-35.

315. See, e.g., id. at 27-28; Louis Kaplow, Rules Versus Standards: An Economic Analysis, 42 Duke L.J. 557 (1992); Sullivan, supra note 311.

316. Sunstein, Legal Reasoning, supra note 177, at 27.

317. Id. at 30.

318. See id. at $28-30$.

319. See supra Part III.A.I. 
(1) Whether plaintiff was located near the scene of the accident as contrasted with one who was a distance away from it. (2) Whether the shock resulted from a direct emotional impact upon plaintiff from the sensory and contemporaneous observance of the accident. ... (3) Whether plaintiff and the victim were closely related, as contrasted with an absence of any relationship or the presence of only a distant relationship. ${ }^{320}$

Factors like these are not "rules" because they do not specify how they are to be weighted in the decisionmaking process (as opposed to strict rules, which have absolute weight-they must be followed), and because they do not purport to be the only grounds upon which decisions may be made. But to the extent such factors exist in an opinion, they constrain in some degree: decisionmakers are forced at least to give the factors some weight in deciding how to act.

Let us ignore for the moment the differences among strict "rules," standards, principles, factors, and related phenomena and think of them, as Cass Sunstein suggests, simply as different points along the same continuum of "ruleness." 321 All such examples of ruleness, when present in a judicial opinion, purport to constrain the decisionmaking of future courts and the arguments of future litigants in some way; they "aspire to make legal judgments in advance of actual [subsequent] cases."322 For this reason all of them-let us call them all just "rules" for now-threaten adjudication as representation. The theory of adjudication as representation gives us reason to distrust any kind of constraining force exerted from one court decision to the next except to the extent that it is directly attributable to interest representation, and sometimes judicially articulated rules purport to exert such an additional constraining force.

2. Rules Versus Results. - Until now I have been speaking rather casually of adjudicative "rulemaking," common law "rules," and the like. But as we have seen, ${ }^{323}$ the common law does not in fact produce binding effects by means of "rules" per se. In fact the common law binds through results: it requires only that courts subject to stare decisis reach the same results as precedential cases with materially similar facts. By this mechanism of constraint, litigants are bound only by rules produced by true interest representatives, that is, materially similarly situated parties. As such, the constraint is legitimized through the operation of adjudication as representation.

The trouble begins when courts depart from this strict, case-by-case common law method. One of the ways courts might stray from the common law is by attempting to articulate rules (or things similar to rules) desigued to constrain future litigants and courts in ways that the simple result of the case could not.

320. Dillon v. Legg, 441 P.2d 912, 920 (Cal. 1968).

321. See Sunstein, Legal Reasoning, supra note 177, at 21-23.

322. Id. at 21 (emphasis omitted).

323. See supra Part II.B.1. 
Recall our second condition for the legitimate operation of adjudication as representation: that the precedential decision bind only those future parties who are similarly situated to the original litigants in every material way. ${ }^{324}$ This condition is met as long as the common law method is strictly observed, ensuring that subsequent litigants will be bound by a prior case only to the extent that the facts of their case are materially similar to the facts of the prior case. To the extent the facts of the two cases are not materially similar, the common law leaves the result up for grabs-or, rather, open to the proofs and reasoned arguments of the parties.

Suppose, however, that instead of simply deciding a case and specifying the facts upon which the decision is based, a court also attempts to articulate a rule according to which future cases should be decided. Imagine that in Case X, facts A, B, and C (and only those facts) are material to the result. If the court in Case $X$ simply decides the case and explains that its decision is based on the presence of facts A, B, and C, a subsequent court in Case $\mathrm{Y}$ will feel itself bound to duplicate the result of Case $\mathrm{X}$ only if the set of material facts in Case $\mathrm{Y}$ also equals $\mathrm{A}, \mathrm{B}$, and $\mathrm{C}$. Thus if Case $\mathrm{Y}$ contains facts $\mathrm{A}$ and $\mathrm{B}$ but not $\mathrm{C}$, or if it contains facts $\mathrm{A}, \mathrm{B}, \mathrm{C}$, and the additional material fact $D$, the Case $Y$ court will not feel itself bound to reach the same result as in Case $\mathrm{X}$; the result of Case $\mathrm{Y}$ will be open to the proofs and reasoned arguments of the parties. ${ }^{325}$

But suppose the court in Case $X$ states its decision in the form of an explicit rule: "Whenever facts A, B, and C are present, result $R$ should obtain." Such a rule looks suspiciously like a statute, and the court in subsequent Case $Y$, especially if it is a lower court reluctant to break new ground, might feel that it is bound both positively and negatively by the rule. The court, that is, might treat the rule not as simply an "if-then" rule- "If facts A, B, and $C$, then result $R$ "- but as an "if and only if" rule"If and only if facts A, B, and C, then result R."

This would produce one (or perhaps both) of two troubling effects with respect to the decision of Case $\mathrm{Y}$. First, the court in Case $\mathrm{Y}$ might believe it is constrained not only to consider facts $\mathrm{A}, \mathrm{B}$, and $\mathrm{C}$ in making its decision, but also to consider only facts $\mathrm{A}, \mathrm{B}$, and $\mathrm{C}$ in making its decision. If there is a potentially relevant additional fact $\mathrm{D}$ in Case $\mathrm{Y}$, then, the court will iguore it in deciding its case. Second, the court in Case $Y$

324. See supra Part II.C.

325. For the sake of making a point, I am ignoring the possibility that the factual difference between Case $Y$ and Case $X$ (say, the presence of additional fact $D$ ) makes Case $\mathrm{Y}$ a stronger case for the result of Case $\mathrm{X}$ than Case $\mathrm{X}$ itself was. If it is true that fact $\mathrm{D}$ makes the argument for that result stronger, then the parties to Case $Y$ can be bound to that result as legitimately as if the facts of the cases were identical. This is so because if the losing litigant in Case $\mathrm{X}$ lost on facts $\mathrm{A}, \mathrm{B}$, and $\mathrm{C}$, then a fortiori she would have lost in what for her would have been a weaker case containing facts $A, B, C$, and D. Her counterpart in subsequent Case $\mathrm{Y}$, then, cannot complain that he is bound to a result not produced by his interest representative. Of course, the question whether a given fact makes the argument for a certain result weaker or stronger is a matter for litigation-for the presentation of proofs and reasoned arguments-among the parties to any subsequent case. 
might also believe that the rule of Case $\mathrm{X}$ forces it to reach a different result than that in Case $X$ whenever one or more of facts $A, B$, and $C$ are not present. If fact $\mathrm{C}$ is missing from Case $\mathrm{Y}$, then, the court will feel bound to reach a result different than $R$ (the result of Case $X$ ). Whichever of these effects is produced in Case $Y$, the constraining force of the Case $X$ result will have been extended beyond the particular facts of that case. The litigants in Case $Y$, that is, will be bound to a certain resulteither $\mathbf{R}$ or $-\mathrm{R}$-despite being dissimilarly situated to the litigants im Case $\mathrm{X}$ in a material way, that is, despite the fact that the litigants in Case $\mathrm{X}$ were inadequate interest representatives of the litigants in Case Y. Adjudication as representation, and thus the democratic legitimacy of Case $\mathrm{X}$ 's constraining force, will be compromised.

Let us see how this sort of hazard to democratic legitimacy actually has played itself out in some real cases.

3. Some Examples.

a. General Rules: Schenck. - As an example of the phenomenon of nonrepresentative constraint at work, recall the Supreme Court's decision in Schenck $v$. United States. ${ }^{326}$ Viewed in the common law mode, the Court in Schenck simply decided that, on the particular facts of that case, the First Amendment did not prohibit the prosecution of the defendant. Under the common law, the binding force of the Schenck decision extended only so far as future cases presented an equivalent set of material facts. Any courts (and the litigants before them) faced with materially different facts than those in Schenck were not bound to the same result.

But Justice Holmes's opinion in Schenck did more than simply state the result and explain how it arose from the facts. It also articulated something that looked like a rule-what became known as the "clear and present danger" test. Holmes wrote: "The question in every case is whether the words used are used in such circumstances and are of such a nature as to create a clear and present danger that they will bring about the substantive evils that Congress has a right to prevent." 327

It is possible to read Holmes's language here as merely a description of the facts upon which, in that particular case, the Court had based its decision-as a simple statement that Schenck (and Schenck alone) was being decided as it was because the facts of that case demonstrated a "clear and present danger" of "substantive evils that Congress has a right to prevent." But it is extremely difficult to limit the import of Holmes's words in this way. When Holmes speaks of "[t]he question in every case," it sounds as if he means just that-as if he intends future courts deciding First Amendment issues to consider those facts (and only those facts) relevant to the question of whether a clear and present danger exists. It also sounds as if Holmes intends that future courts faced with facts that do not amount to a clear and present danger should consequently reach a differ- 
ent result than that of Schenck-they should automatically acquit defendants prosecuted for subversive speech, regardless of whether other potentially relevant facts exist. It sounds, that is, as if Holmes is stating a rule intended to constrain both positively, by specifying what result must obtain upon a certain set of facts, and negatively, by requiring future courts to consider only that set of facts and to reach a different result if all of those facts are not present.

Now imagine a defendant in a subsequent case implicating Schenck. Suppose that instead of a socialist distributing leaflets against the draft, the subsequent defendant is a museum curator who is arrested for displaying photographs deemed to be pornographic. Absent Holmes's rulelike clear and present danger language, the subsequent defendant probably could disregard Schenck as a potentially controlling precedent ${ }^{328}$ because the facts of the two cases are so dissimilar. But the subsequent defendant must contend with that language, which purports to allow government regulation of speech any time there is a "clear and present danger that [it] will bring about the substantive evils that Congress has a right to prevent." 329 As such, the defendant must attempt to prove not simply that his case is materially different from Schenck, but also that his conduct, regardless of any similarity or difference in comparison to the conduct of the Schenck defendant, does not produce a clear and present danger of this sort. The result may be a conviction where none would have occurred absent Holmes's rule-like language. Even if the result is an acquittal on First Amendment grounds, the subsequent defendant has in a very real sense been bound by the clear and present danger rule: $\mathrm{He}$ has been forced to prove that his conduct did not violate the prohibition that rule establishes. (And, of course, the prosecuting authorities also have been bound by the clear and present danger test despite their dissimilarities with the prosecutors in Schenck.)

This binding force has arisen from a decision in which no true interest representative of the subsequent defendant participated. The antiwar socialist defendant in Schenck cannot by any stretch of the imagination be thought to have had many interests in common with the museum curator in the subsequent case (except, perhaps, an interest in unfettered expressive conduct in the broadest sense). As such, the second necessary condition of adjudication as representation has been violated, and the binding force of the Schenck clear and present danger rule is democratically illegitimate with respect to the subsequent defendant.

The question of whether Schenck's clear and present danger test had some binding force over and above the simple common law force of the result in Schenck did in fact surface in Dennis v. United States. ${ }^{330}$ The defendants in Dennis, remember, were "the leaders of the Communist Party

328. But Schenck still might he a persuasive precedent in this later case. See supra text accompanying note 182 .

329. Schenck, 249 U.S. at 52.

330. 341 U.S. 494 (1951). 
in this country" 331 who were charged under the Smith Act with "'knowingly or willfully advocat[ing] . . . the duty, necessity, desirability, or propriety of overthrowing or destroying any government in the United States by force or violence"“332 and for "organiz[ing]" for that purpose. ${ }^{333}$ The problem for the prosecutors in Dennis was that, in contrast with Schenck, there did not seem to be any immediate danger that the defendants would accomplish any part of their objective. Unlike in Schenck, Dennis was prosecuted in peacetime, and the defendants sought to achieve the somewhat unlikely goal of "a violent revolution" 334 overthrowing the entire United States government rather than simply a few desertions or acts of passive resistance against the armed forces. Thus the prosecutors in Dennis were faced with more than just the task of persuading the Court that, despite the material dissimilarities between their case and Schenck, the same result should obtain; they also had to fit the facts of their case within the Schenck clear and present danger language, arguably a more difficult row to hoe. They were, that is, bound by the clear and present danger rule despite the material differences between their case and Schenck.

In upholding the convictions in Dennis, the Court openly struggled with the issue of precisely how binding the clear and present danger test was apart from the bare result of Schenck. The Court ultimately resolved the problem by denying that the test had (or was intended to have) much binding force at all:

Justice Holmes ... [n] ever envisioned that a shorthand phrase should be crystallized into a rigid rule to be applied inflexibly without regard to the circumstances of each case. Speech is not an absolute .... Nothing is more certain in modern society than the principle that there are no absolutes, ${ }^{335}$ that a name, a phrase, a standard has meaning only when associated with the considerations which gave birth to the nomenclature. To those who would paralyze our Government in the face of impending threat by encasing it in a semantic straitjacket we must reply that all concepts are relative. ${ }^{336}$

Thus the Court in Dennis labored to free itself from the separate constraint of the clear and present danger rule and to acknowledge only the binding force of the result of Schenck itself, of the particular case "which gave birth to the nomenclature." We may not favor the outcome of Dennis, and indeed we may believe that the outcome would have been better had the Court in that case clung more tightly to the clear and

331. Id. at 497.

332. Id. at 496 (quoting the Smith Act, 18 U.S.C. $\$ \S 10,1 \mathrm{I}(2)(a)(1)(1946)$ )).

333. Id. (quoting the Smith Act, 18 U.S.C. $\S \S 10,11(2)(a)(3)$ (1946)).

334. Id. at 497.

335. The self-contradiction inherent in this statement can hardly go unremarked: Justice Vinson, the author of the plurality opinion, is in effect stating as an absolute rule that there are no absolute rules.

336. Dennis, 341 U.S. at 508 (citation omitted). 
present danger formulation. But from the perspective of adjudication as representation, ${ }^{337}$ we have to acknowledge that the Court's instincts were correct. The litigants in Dennis should not have been bound by the clear and present danger rule, because the litigants in Schenck were differently situated and thus were inadequate representatives of their interests. The constraining force of Schenck should indeed have run out where the material similarities between it and Dennis stopped.

b. Multifactor Tests: Dillon. - The Schenck clear and present danger language probably falls on that half of the "ruleness" continuum whose end is occupied by strict rules; it is not itself a strict rule allowing no discretion in individual cases, but it is at least a standard confining the potential outcomes within a fairly limited range. Closer to the other end of the spectrum are "factors," enumerated factual conditions whose presence or absence must be considered by subsequent courts in making decisions but whose relative weight is indefinite. When courts announce such factors in deciding cases, though, the resulting constraint on future courts can be just as illegitimate from the standpoint of adjudication as representation as the constraint produced by stricter rules.

Dillon v. Legg ${ }^{338}$ is a salient example. In that case, the California Supreme Court listed three specific "factors" that courts in subsequent cases should "take into account" in deciding whether bystander emotional injuries are foreseeable: (1) the proximity of the plaintiff to the accident; (2) the existence or nonexistence of a direct "sensory and contemporaneous observance" of the accident by the plaintiff; and (3) the degree of intimacy in the relationship between the accident victim and the plaintiff. ${ }^{339}$ Like the clear and present danger test of Schenck, this "multifactor test" lent itself to interpretation in later cases as an indepen-

337. As a criminal case, Schenck reminds us with particular saliency that the perspective of adjudication as representation often will not be the only perspective from which we can assess the overall rightness of a judicial decision. There may be strong reasons for courts to articulate broad rules even if doing so compromises the representative legitimacy of the decision. One such reason that arises in the criminal context, and perhaps especially in the First Amendment context, might be a concern for fair notice to potential actors about the possible criminal consequences of their actions. A court-articulated broad mle like the clear and present danger test might fulfill the notice function better than a minimalist, fact-specific decisionmaking approach would. The presence of this kind of concern, of course, does not undermine the theory of adjudication as representation; it merely suggests that such concerns would have to be balanced against concerns of democratic legitimacy in determining how a case should be decided (and how the resulting opinion should be written).

338. 441 P.2d 912 (Cal. 1968).

339. Id. at 920 . Interestingly, the Dillon court implied that these factors should not be considered exclusive:

[F]oreseeability ... must necessarily be adjudicated only upon a case-by-case basis. ... [N]o immutable rule can establish the extent of [a defendant's] obligation for every circumstance of the future. ... .

...

... All these elements, of course, shade into each other; the fixing of obligation, intimately tied into the facts, depends upon each case. 
dently binding rule separate and apart from the result of Dillon itself. A later court easily might have interpreted this list of factors not simply as a description of how the Dillon court reached its particular result, but as a rule intended to apply in future cases (to "the courts," in the language of the Dillon opinion ${ }^{340}$ ) and looking something like this: If and only if facts $P$ (proximity to the accident), $O$ (direct observance of the accident), and $R$ (close relationship between victim and plaintiff) are present, then result $L$ (potential liability) obtains. The subsequent court might then have felt bound by Dillon to reach a particular result even on facts materially different from those of Dillon. It might have felt bound to reject liability where, say, fact $O$ is absent, despite the presence of the other factors or even of a fourth material fact. Or it might have felt bound to impose liability in the presence of facts $P, O$, and $R$ even where a fourth fact $F$ suggests that liability should not be imposed.

In this way Dillon, like Schenck, had the potential to bind future litigants in situations where interest representation did not function. Indeed, consider Deboe v. Horm, in which a panel of the California Court of Appeal declined to extend Dillon to allow recovery to a plaintiff who had not actually witnessed the accident but had observed her husband's severe injuries at the hospital. ${ }^{341}$ As I suggested above, ${ }^{342}$ Deboe might well be legitimate; it might be seen as a case in which the court recognized material dissimilarities to Dillon and decided, after proofs and reasoned arguments from the parties, not to reach the Dillon result. But the perfunctory opinion in Deboe suggests that in fact the court largely ignored this second step-that it automatically equated the existence of dissimilarity between its case and Dillon with the necessity to reach a different result than in Dillon. The Deboe court quoted the entire passage from Dillon in which the Dillon court set forth its three-factor test and then asserted baldly that, on the facts alleged by the plaintiff, "no liability would exist as a matter of substantive law." ${ }^{443}$ It is thus difficult to shake the impression that the court in Deboe felt itself bound not simply (or even primarily) to the result of Dillon, but also (or instead) to the threefactor test articulated by the Dillon court. If Deboe is read this way, the absence of one of the factors enumerated in Dillon was deemed automatically to dictate a result different from that of Dillon. The litigants in Deboe, despite their dissimilarity to those in Dillon, may have found themselves bound negatively by that case-not to the result of Dillon, but to the opposite result.

Id. at 920-21. These caveats were virtually ignored by subsequent courts at all levels until the decision in Ochoa v. Superior Court, 703 P.2d 1, 8 (Cal. 1985) ("It is important to remember that the factors set forth in Dillon were merely gnidelines to be used in assessing whether the plaintiff was a foreseeable victim of the defendant's negligence.").

340. Dillon, 441 P.2d at 920.

341. See 94 Cal. Rptr. 77, 79 (Ct. App. 1971).

342. See supra Part III.A.3.

343. Deboe, 94 Cal. Rptr. at 79-80. 
4. The Democratic Illegitimacy of Court-Produced General Rules. - When, as in Schenck and Dillon, a court goes beyond merely deciding its case and articulates a rule that could be interpreted by subsequent courts as binding, adjudication as representation potentially breaks down. Subsequent litigants may find themselves constrained by rules created by parties to prior cases who, because they were not similarly situated to the subsequent litigants, were not adequate interest representatives of those litigants. This can happen in one of two ways. The subsequent court may interpret the fact that its case does not conform with the rule (because, for instance, it lacks one or more facts specified by the rule as necessary) to automatically require a result different from that of the precedential case. Arguably, the court in Deboe committed this error. Or the subsequent court, in making its decision, may refuse to consider the potential effect of facts other than those specified by the rule, thus binding the litigants to the same result as in the precedential case even where mitigating factors argue against it. A court deciding our hypothetical museum pornography case might have committed this kind of error. Under either circumstance, the parties to the subsequent case have been illegitimately bound; the result of their case has been determined in part by a rule made by non-interest representatives.

The theory of adjudication as representation thus gives us a new perspective on the debate about rules. It tells us that courts should try to avoid articulating rules and using rule-like language (the language of "standards," "factors," "guidelines," and so on) not merely because of the practical problems and troubling consequences of applying such rules, as Cass Sunstein has argued, ${ }^{344}$ but also because of the inherent illegitimacy of applying them. Of course, there may be competing reasons favoring the use of such rules in certain contexts. But the more we are concerned with preserving democratic legitimacy in adjudication, the less we should tolerate judicially promulgated rules.

The theory of adjudication as representation also sheds some light on the ubiquitous propensity of modern courts to articulate multifactor tests designed to guide the decisions of future courts. Multifactor tests have tended to receive the approbation of commentators who generally disfavor judicially propagated rules ${ }^{345}$ and the condemnation of commentators who generally like such rules. ${ }^{346}$ But the theory of adjudication as representation suggests that multifactor tests are not all that different from stricter rules in the way in which they constrain future courts.

344. See Sunstein, Legal Reasoning, supra note 177, at 121-35. Professor Sunstein appears to confine his attack to strict rules, or at least to those phenomena that are near strict rules on the "ruleness" continuum. He does not extend his critique to factors and the like. For instance, in discussing the problem of strict rules that produce nonsensical results in particular cases, Sunstein suggests that "[p]erhaps it would be best to dispense with rules and instead to allow [people] to comply [with the law] by showing adequate performance under a set of factors." Id. at 131.

345. See, e.g., id. at 136-47.

346. See, e.g., Scalia, supra note 11, at 1178-79, 1182. 
As in Dillon, they tend to dissuade future courts both from reaching similar results when every listed factor is not present, and from reaching different results when every listed factor is present but other factors militate in the opposite direction. Like stricter rules, multifactor tests invariably take on lives of their own, separate from the facts and results of the decisions that produce them; any modern constitutional scholar can confirm this phenomenon. In such cases, the tests threaten to bind dissimilar litigants and thus to undermine adjudicative legitimacy.

Of course, it is one thing to condemn judicial articulation of general rules and quite another thing to distinguish that phenomenon from the act of simply deciding a case and giving reasons for that decision. Adjudication as representation suggests that courts should give reasons for their decisions, to allow both comparison of the facts of subsequent cases and monitoring for responsiveness to the arguments of the parties. But the distinction between general rulemaking and case-by-case decisionmaking may not be all that difficult to draw. Not surprisingly, much of the problem can be solved by simple adjustments in language. Had Holmes, in writing the Schenck opinion, omitted the introductory phrase "The question in every case is whether"347 and replaced it with the phrase "In the instant case," much of the independent force of the "Clear and present danger" language inight have withered on the vine: "clear and present danger" might have looked more like simply a description of the facts in the Schenck case itself. The same thing can be said for soine of the Dillon opinion's language: Declaring that it is "defin[ing] guidelines which will aid in the resolution of such an issue as the instant one"348 and then separately numbering a list of "factors" for "the courts [to] take into account" 349 seems (as the Dillon court surely knew) a surefire way to establish an independent, self-sustaining rule. From the perspective of adjudication as representation, the better course is simply to describe the particular factual circumstances upon which a court is resting its decision and to tell how the decision proceeds from them. Any hint of generality is certain to be taken by future courts, with illegitimate results close behind.

\section{B. Judicial Review}

The real problem of the supposedly counter-majoritarian tendency of judicial review is that so much of the normative work of the courts occurs through a process that is exclusionary rather than participatory.

Steven L. Winter 350

347. Schenck v. United States, 249 U.S. 47, 52 (1919).

348. Dillon v. Legg, 441 P.2d 912, 920 (Cal. 1968).

349. Id.

350. Winter, supra note 128 , at 1507 . 
It is always important at the outset to focus precisely on the controversy before the Court.

\section{Regents of the University of California $v$. Bakke (opinion of Stevens, J.) $)^{351}$}

To a significant extent, the debate over rules discussed in the previous section has occurred as part of the continuing, arguably larger debate over the proper scope of judicial review. ${ }^{352}$ A number of respected constitutional scholars recently have suggested that there are particularly good reasons to avoid the articulation of broad rules in constitutional decisions and to proceed instead on a gradual, case-by-case basis. ${ }^{353}$ The theory of adjudication as representation adds one more good reason to avoid rules: the preservation of democratic legitimacy in adjudication. This reason applies to constitutional cases in the same way we have already seen it apply to judicial decisions generally.

But constitutional cases can pose special problems. Often they are cases of tremendous import extending beyond merely the litigants before the court and similarly situated future litigants. They involve not simply the application, modification, or rejection of a rule made by a previous court, but the potential invalidation of a democratically enacted statute. And the parties to such cases frequently do not fit the common law model of private, self-interested litigants seeking to resolve a dispute. What does the theory of adjudication as representation have to say about these unusual features?

The theory, as we will discover momentarily, finds judicial review problematic froin the standpoint of democratic legitinacy-not because it often results in the invalidation of majoritarian statutes, but because the effects of such an invalidation often extend to people whose interests have not adequately been represented before the invalidating court. But the theory also suggests soine remedies for this pathology. It favors both judicial ininimalisin in the constitutional review of statutes and increased participation by interested parties and groups in the adjudicative process. Together, these prescriptions might substantially increase the democratic legitimacy of constitutional adjudication.

1. Two Types of Constitutional Decisions. - To see why this is so, it will be helpful to divide our topic into two types of constitutional decisions, viewed froin an ex post perspective. The first type simply consists of those decisions in which the party challenging a statute on constitutional grounds-let us call her the plaintiff, although of course she could also

351. 438 U.S. 265, 408 (1978) (Stevens, J., concurring in part and dissenting in part) (footnote omitted).

352. See, e.g., Sunstein, Legal Reasoning, supra note 177, at 10-12, 136-90; Scalia, supra note 11, at 1182-84; Sullivan, supra note 311, at 112-21.

353. See Sunstein, Legal Reasoning, supra note 177, at 171-82; Brilmayer, supra note 176 , at 812-13; Strauss, supra note 258, at 935; Cass R. Sunstein, The Supreme Court, 1995 Term-Foreword: Leaving Things Undecided, 110 Harv. L. Rev. 6, 33-44 (1996). 
be a civil or criminal defendant-loses, and the constitutionality of the statute or provision being challenged is upheld. The second type consists of those decisions producing the opposite result: the plaintiff wins, and the challenged statute, or the challenged provision of a statute, is declared invalid by the court on constitutional grounds.

From the perspective of adjudication as representation, the first type of constitutional decision, the one in which the plaintiff loses, typically can be analyzed the same way we would analyze a common law decision. The court in such a case, if it has adhered to the common law method, simply has decided that, on the particular facts of that case, the statute may constitutionally be applied to the plaintiff to yield a certain result. As with a common law case, the only binding portion of such a decision is its result: who has won, and on what set of facts? Future courts and litigants then will be bound by the decision only to the extent that the facts of their cases materially coincide with the facts of the precedential case. Adjudication as representation can operate properly under such conditions to legitimize the binding effects of the case on future parties.

Of course, this type of constitutional case, where the plaintiff loses, is susceptible to the risk of judicial rule-stating discussed in the previous section. Holmes in Schenck succumbed to this risk. Instead of simply deciding that, on those particular facts, the plaintiff (actually, the criminal defendant in Schenck) lost-that is, the statute could be applied constitutionally-he uttered the language of a rule ("clear and present danger") apparently intended to have binding effect separate and apart from the result of the case. For the reasons we have discussed, the theory of adjudication as representation frowns on this kind of judicial ambition. Just as in other types of cases, courts upholding statutes against constitutional challenges should avoid the articulation of general rules to govern future cases if those courts want to preserve adjudicative legitimacy.

In contrast, the second type of constitutional decision, the one in which the plaintiff wins, must be viewed somewhat differently from the typical common law decision. In fact, this type of case itself can be subdivided into two subcategories: those decisions in which only the application of a statute on certain facts is held to be unconstitutional, and those decisions in which the statute itself, or a portion of it, is wholly stricken down as unconstitutional.

Decisions in the first subcategory can be analyzed exactly like decisions in which the plaintiff loses; they are like common law decisions, and, unless the court has articulated a broad rule, only the results are controlling. Subsequent courts and litigants will be bound only to the extent that the facts of those cases materially coincide with the facts of the precedential case. (The Supreme Court's decision in Brandenburg $v$. Ohio, ${ }^{354}$ discussed in a previous section, ${ }^{355}$ is an example of such a case.) 
Decisions in the second subcategory, though, are inherently different from the typical common law decision. In such cases, more than a simple fact-specific result has occurred: An entire statute, or a portion of an entire statute, has been declared constitutionally invalid on all potential facts, with respect to everyone. The court in a case like this is in essence forced to answer a "yes or no" question: Is the statute unconstitutional, or isn't it? Faced with a "yes" answer to this kind of yes or no question, a subsequent litigant cannot attempt to distinguish the decision; he cannot argue that the statute is not invalid as to him because the facts of his case differ from those of the precedential case. The subsequent litigant will be bound by the statute's invalidation, even if he is not similarly situated to (and thus his interests were not adequately represented by) a party to the prior case. Indeed, because statutes typically affect the lives of a wide variety of dissimilarly situated people, a court's invalidation of a statute almost always will in some sense bind parties who are very different from those who participated in the invalidating decision. Many. of those parties automatically will be affected as soon as the operation or enforcement of the invalidated statute ceases.

From the standpoint of adjudication as representation, decisions striking down statutes on constitutional grounds thus inherently produce some degree of illegitimacy. The second necessary condition of adjudication as representation, the binding only of similarly situated parties, will always be violated to some extent by such decisions. This is because the precedential decision always will bind more than just those future litigants (or, more significantly, those affected nonlitigants) who are similarly situated to the original litigants in a material way. Must we therefore despair for the democratic legitimacy of such decisions? Are we thrust back into the clutches of Alexander Bickel's "counter-majoritarian difficulty"?356

2. The Government As a Party. - Not entirely. For one thing, much of the perceived democratic illegitimacy of judicial invalidation of statutes often will be illusory in an important way. Remember that one of the parties to constitutional cases, the party defending the statute at issue, typically will be the government in some form-the prosecuting attorney, the state attorney general, the U.S. attorney, the Solicitor General. These parties are (or are made up of) officials who are democratically elected or who are appointed by other officials who have been democratically elected. As such, they are presumed to carry out their duties in a way that is responsive to and reflective of the wishes of the public. Perhaps more to the point for adjudication as representation, they are charged with representing the public interest; they are supposed to do their jobs with the same focus on the interests of their constituents that a legislator is presumed to possess. While they may not be interest representatives by virtue of exact similarity of situation, they are legitimate representatives in 
the primary democratic sense of direct, electorally induced responsiveness to the public good. Thus their activities can be considered legitimately binding on us in the same sense that the activities of Congress or the President can, and if they lose a legal challenge to a statute that we support, we cannot claim that their representation of us in the proceedings was democratically illegitimate.

So the mere fact of government participation in a constitutional challenge inserts legitimacy into the result of the challenge that might otherwise be lacking from the perspective of adjudication as representation. Of course, government cannot coherently represent every diverse interest that will be impacted if a statute is invalidated; some of those interests will conflict with one another. And there will always be those cases involving constitutional challenges to statutes in which the government is not a party; Fletcher v. Peck, ${ }^{357}$ Dred Scott v. Sandford, ${ }^{358}$ and Home Building E' Loan Ass'n. v. Blaisdell ${ }^{359}$ are some well-known examples. But although judicial review cases inevitably will threaten representational legitimacy as a result of these facts of life, the theory of adjudication as representation suggests ways to reduce this threat significantly.

3. Minimalism and the "Passive Virtues." - One obvious lesson of adjudication as representation is that courts striking down statutory provisions should be as minimalist as possible in doing so. ${ }^{360}$ They should decline to reach constitutional questions unless they must decide them to decide the case; they should invalidate only those portions of a statute implicated by the facts of the particular case; and they should avoid using langnage that would suggest, in the words of one Supreme Court Justice, "any opinion about the legal status of any [statute] other than" the one before the court. $^{361}$ In this sense, their decisions, and the opinions reporting them, should be what Cass Sunstein has called "narrow." 362 Narrowness of decisionmaking avoids binding unrepresented future litigants and affected nonlitigants to any greater extent than is absolutely necessary in striking down a statute. For the same reason, courts should be careful not to theorize their decisions too deeply; ${ }^{363}$ they should avoid justifying their decisions with comprehensive principles other than those necessary to explain how the facts of a particular case produce the result reached. Comprehensive principles, like strict rules, multifactor tests, and other examples of "rnleness," can be treated by future courts as binding over

357. 10 U.S. (6 Cranch) 87 (1810).

358. 60 U.S. (19 How.) 393 (1856).

359. 290 U.S. 398 (1934).

360. I borrow the term "minimalist" in this context from Cass Sunstein. See Sunstein, supra note 353 , at $6-7$.

361. Regents of the Univ. of Cal. v. Bakke, 438 U.S. 265, 408 (1978) (Stevens, J., concurring in part and dissenting in part). Justice Stevens was referring to the state medical school admissions program at issue in Bakke.

362. See Sunstein, supra note 353, at 15-20.

363. Here again I borrow terminology from Professor Sunstein. See Sunstein, Legal Reasoning, supra note 177, at 35-61; Sunstein, supra note 353, at 20-21. 
and above the simple result of the case producing them and, as such, can threaten representational legitimacy.

Another lesson of the theory of adjudication as representation might seem to be one of support for the "passive virtues," Alexander Bickel's name for the strategic use by courts (particularly the Supreme Court) of justiciability doctrines and other procedural techniques to avoid deciding issues the Court believes are best deferred to a later date. ${ }^{364}$ Bickel favored the passive virtues mostly for prudential reasons: He believed that the Court sometimes should conserve its political capital and encourage democratic processes by declining to speak on a controversial issue until just the right moment in the national debate. ${ }^{365}$ Adjudication as representation, at least on the surface, appears to provide an additional prudential reason for a court carefully to pick and choose the constitutional cases it accepts. Knowing that it might be about to make a rule (through invalidation of a statute) that will affect people other than the parties before it, a court might choose not to adjudicate a case that seems particularly ill-suited to the production of an accurate rule. That is, a court might reject a case featuring litigants who are not representative of those typically affected by the statute, ${ }^{366}$ or bearing facts that do not seem fully enough developed to support a completely informed decision. In rejecting such cases and waiting for, in Bickel's phrase, a "well-tempered case," 367 a court might be seen to promote legitimacy by ensuring that a statute will be invalidated, and thus nonlitigants will be bound, only for the best of reasons and with the greatest possible amount of information before the court.

Ultimately, however, the theory of adjudication as representation rejects the passive virtues. Recall the first necessary condition for legitimacy under that theory: that the binding decision actually be produced to a significant degree by the litigants. ${ }^{368}$ A judicial refusal to review a statute for constitutionality can bind just as strictly as an adjudicative invalidation of the statute can; when it occurs, parties subject to the operation of the potentially unconstitutional statute are left without redress, are bound to the continued. unconstitutional operation of the statute itself. Such a decision, that is, binds the litigants to the status quo. But unlike an adjudicative decision invalidating a statute on constitutional grounds, a strategic judicial decision not to review the statute has little or no basis in the proofs and reasoned arguments of the parties; it is not actually produced

364. See Bickel, supra note 307 , at 111-98.

365. See id.; see also Sunstein, supra note 353, at 36-42 (discussing "democracyforcing" aspects of judicial minimalism).

366. I will explore this particular possibility in more depth during my discussion of justiciability doctrines in the next section. See infra Part IV.C.

367. Bickel, supra note 307, at 169 .

368. See supra Part II.C. 
to a significant degree by the litigants. ${ }^{369}$ Indeed, the effect of such a decision is to foreclose the presentation of proofs and reasoned arguments on the issue. Even where an exercise of the passive virtues follows briefing by the litigants-as, for instance, on dismissal of a case for want of standing or denial by the Supreme Court of certiorari-the court's decision will not actually be responsive to the arguments of the parties if it is based upon extraneous criteria such as the imprudence of adjudicating the issue at that time or the possibility that adjudication will produce an unsatisfactory rule. In short, a self-conscious, prudential exercise of the passive virtues by a court usually will undermine legitimacy from the perspective of adjudication as representation.

The theory of adjudication as representation, then, suggests that courts should not avoid deciding constitutional cases for prudential reasons. Instead they should act as minimalists when presented with a constitutional issue: They should decide it only if necessary to decide the case, and they should not invalidate a statute unless the facts of the particular case require it. If possible (and it will not always be), courts should invalidate a statute's application on particular facts rather than striking down an entire statutory provision. In these ways, courts can limit themselves to deciding only what is necessary while avoiding the potential legitimacy problems of a decision not to decide.

4. Broad Participation. - Finally, adjudication as representation suggests that courts faced with constitutional challenges to statutes should actively ensure that the voices of as many diverse interests as possible are heard during the adjudicative process. Government agencies charged with interpreting and enforcing the statute at issue should be allowed, even encouraged, to intervene in the proceedings. ${ }^{370}$ Amicus curiae briefs and arguments should be entertained, even solicited, from a wide

369. "The greatest freedom of judicial choice lies in determining the appropriateness of the issues for judicial decision." 13 Charles Alan Wright et al., Federal Practice and Procedure \$ 3529, at 287 (2d ed. 1984).

370. Pursuant to Federal Rule of Civil Procedure 24(b), a federal court may in its discretion allow a government officer or agency to intervene whenever "a party to an action relies for ground of claim or defense upon any statute or executive order administered by [that] ... agency or upon any regulation, order, requirement, or agreement issued or made pursuant to the statute or executive order." Fed. R. Civ. P. 24(b). 
variety of potentially affected interest groups. ${ }^{371}$ Joinder and intervention should be liberally permitted. ${ }^{372}$

These conclusions may at first seem counterintuitive in light of the importance to adjudication as representation of the common law method, a model of adjudicative decisionmaking whose usual medium is the traditional sort of lawsuit between two private individuals seeking mutually opposed results. ${ }^{373}$ But while it is important for adjudication as representation to preserve those aspects of traditional adjudication-that is, of the common law method-that pass along only those binding rules created by interest representation, it is equally important to ensure that interest representation occurs in the first place in the precedential case. To a certain extent, deficiencies in the former process can be cured by tinkering with the latter. Encouraging active participation in the litigation by affected interest groups can largely compensate for the fact that the court's invalidation of a statute will extend beyond those parties whose interests are represented by the core litigants in the case. As such,

371. Federal Rule of Appellate Procedure 29 allows most amicus curiae briefs to be filed "by written consent of all parties, or by leave of court," although the federal government is allowed to file amicus briefs without consent or leave. Fed. R. App. P. 29. Motions for leave to file amicus briefs must "identify the interest of the applicant and ... state the reasons why a brief of an amicus curiae is desirable." Id. Supreme Court Rule 37 similarly allows amicus briefs only by consent of the parties or leave of Court, specifically encouraging amicus briefs "which bring[ ] to the attention of the Court relevant matter that has not already been brought to its attention" but discouraging briefs not serving this purpose as a "burden [ ] [on] the Court." Sup. Ct. R. 37.

372. The current Federal Rules require joinder of a person whose ability to protect an "interest relating to the subject of the action" might "as a practical matter [be] impair[ed] or impede[d]" by her absence, as long as joinder is feasible and would not defeat the court's jurisdiction. Fed. R. Civ. P. 19(a). The Rules also require a court to permit intervention of persons whose interests may be impaired or impeded unless those interests are "adequately represented by existing parties." Fed. R. Civ. P. 24(a). The Rules allow permissive joinder and permissive intervention of persons with claims or defenses sharing questions of law or fact common with those already present in the case. Fed. R. Civ. P. 20(a), 24(b).

The theory of adjudication as representation suggests that these rules be interpreted liberally in constitutional cases to allow joinder of, and intervention by, any party with a distinct interest potentially implicated by the case whose interests are not already, in the language of Rule 24, "adequately represented by existing parties." If the Rules cannot fairly be read to allow joinder or intervention to such an extent, the theory suggests that they should he amended to do so.

As a sidelight, it is instructive to note the degree to which the concept of interest representation is embodied in these and other Federal Rules, particularly the class action provisions. See, e.g., Fed. R. Civ. P. 23(a) (requirements that claims or defenses of named parties in class actions be "typical of the claims or defenses of the class" and that the named parties "fairly and adequately protect the interests of the class").

373. For a classic exposition of this bipolar model and a comparison of that model with modern public law litigation, see Abram Chayes, The Role of the Judge in Public Law Litigation, 89 Harv. L. Rev. 1281 (1976). 
it can bolster the representational legitimacy that is threatened by the imperfect operation of interest representation in such cases. ${ }^{374}$

The need for broad participation might also seem at odds with the belief held by Lon Fuller (and endorsed by Hart and Sacks) that disputes involving a multiplicity of parties and interests, what Fuller called "polycentric" disputes, are inappropriate for adjudication because of their inherent complexity. ${ }^{375}$ In a sense a conflict does indeed exist. The theory of adjudication as representation gives us a reason for, in effect, turning some "monocentric" disputes into "polycentric" disputes: to preserve the democratic, representational legitimacy of the result. But the theory does not contradict the conclusion drawn by Fuller and by Hart and Sacks that these sorts of complicated, polycentric controversies are more effectively resolved by nonadjudicative means-private negotiation, for instance, or legislation. ${ }^{376}$ The theory only suggests that if such disputes are to be resolved by adjudication, they should, to preserve democratic legitimacy, be resolved with the participation of as many affected interests as possible.

5. Adjudication As Representation, the "Counter-Majoritarian Difficulty," and the Assumption of Constitutional Supremacy. - Viewed through the lens of adjudication as representation, then, judicial review might not seem quite so problematic an antithesis to democratic government as is usually believed. Constitutional cases often will not be perfect examples of adjudication as representation in operation, but judicial minimalism and broad participation can bring them fairly closely into line with the common law model of interest representation. By that model, no one bound by a judicial decision is bound illegitimately; everyone constrained by a decision, even a constitutional decision, will have had her interests represented in the decisionmaking process, and even the invalidation of democratically enacted statutes will therefore occur by democratically legitimate means. As such, if constitutional adjudication is done in a certain way, the "counter-majoritarian difficulty" of judicial review begins to look a lot less difficult: The process of judicial review may not be majoritarian,

374. Existing parties to a litigation, of course, often will have no incentive to argue for the inclusion of additional interest groups, and indeed may have incentives to oppose their participation. This means that the court probably will have to take an active role in soliciting the participation of such groups and determining whether and how a particular group should be allowed to participate. This judicial role, however, need not conflict with the ideal of extensive and meaningful litigant control of the litigation as long as it is limited in function and guided by procedural rules (as, for instance, the judge's function in the certification of class actions currently is, see Fed. R. Civ. P. 23). Indeed, it seems probable that in high-profile cases, a wide variety of interest groups will quickly make themselves known to the court if the possibility of their meaningful participation is perceived to be a real one. The court's role then will become more the traditional one of taking proofs and hearing reasoned arguments, albeit on the somewhat nontraditional issues of whether a particular interest should be represented in the litigation and whether a certain group adequately represents that interest.

375. See Hart \& Sacks, supra note 259, at 646-47; Fuller, supra note 133, at 393-405.

376. See Hart \& Sacks, supra note 259 , at 647 ; Fuller, supra note 133, at 393-405. 
but it is democratic in a sense closely akin to that of majoritarian lawmaking.

The theory of adjudication as representation thus suggests that how to apply the Constitution is something of a democratic choice after all. The implications of this suggestion are simultaneously comforting and troubling. They are comforting because they tell us that judicial review is not so susceptible to the whims and politics of particular judges as it might seem, that constitutional adjudication is not ultimately a matter of rule by judicial fiat. They are troubling because they shift the question of the countermajoritarian difficulty to another, higher level: They force us to face the tension between a supposedly immutable, "metademocratic" Constitution on the one hand, and a primarily democratic procedure for determining what that Constitution means on the other. The trouble no longer is the apparent anomaly of allowing nonelected judges the power to invalidate majoritarian statutes. Instead, the trouble has become the practice, no less anomalous, of subjecting the Constitution-a document of metademocratic commitment that supposedly is immune to the vagaries of everyday democracy-to interpretation by a process that is itself significantly democratic.

Adjudication as representation therefore challenges a long-held assumption of constitutional law, the assumption of constitutional supremacy. Exploring the ramifications of such a challenge is simply beyond my scope here. But let me tentatively suggest that subjecting the Constitution to interpretation through a democratic process of participation by those affected is at least a preferable alternative to interpretation at the unfettered discretion of a judge or panel of judges. The former process gives expression to the fundamental democratic tenet of participatory government; the latter succumbs to the dangers of rule by fiat.

\section{Justiciability Doctrines}

[A] Court of Justice acting as such ... does not declare the law eo nomine and in the abstract, but waits until a case between man and man is brought before it judicially involving the point in dispute: from which arises the happy effect that its declarations are not made in a very early stage of the controversy; . . . that the Court decides after hearing the point fully argned on both sides by lawyers of reputation; decides only as much of the question at a time as is required by the case before it, and its decision ... is drawn from it by the duty which it cannot refuse to fulfil, of dispensing justice impartially between adverse litigants.

John Stuart Mill377

377. Mill, Representative Government, supra note 61, at 403 . 
The Art[icle] III aspect of standing ... reflects a due regard for the autonomy of those persons likely to be most directly affected by a judicial order.

Valley Forge Christian College v. Americans United for Separation of Church and State, Inc. ${ }^{378}$

Intimately connected with debates about judicial review are questions about the proper scope and use of justiciability doctrines-doctrines emerging primarily from Article III's "case or controversy" requirement ${ }^{379}$ and limiting the circumstances in which courts can adjudicate issues. As "public law" litigation has grown in importance over the last half century, academic contention over the role of justiciability doctrines, especially the three most important of them-standing, ripeness, and mootness-has raged. ${ }^{380}$ The most significant voices on the subject, those of the nine members of the Supreme Court, have themselves rarely been in harmony about it. ${ }^{381}$ The result has been a twisting maze of deci-

378. 454 U.S. 464,473 (1982).

379. Article III, Section 2, Clause 1 of the Constitution reads:

The Judicial Power shall extend to all Cases, in Law and Equity, arising under this Constitution, the Laws of the United States, and Treaties made, or which shall be made, under their Authority;-to all Cases affecting Ambassadors, other public Ministers and Consuls;-to all Cases of admiralty and maritime Jurisdiction;-to Controversies to which the United States shall be a Party;- -to Controversies between two or more States;-between a State and Citizens of another State;between Citizens of different States;--between Citizens of the same State claiming Lands under Grants of different States, and between a State, or the Citizens thereof, and foreign States, Citizens, or Subjects.

U.S. Const. art. III, $\S 2$, cl. 1.

380. See, e.g., Brilmayer, supra note 176; Brilmayer, supra note 191; Lea Brilmayer, A Reply, 93 Harv. L. Rev. 1727 (1980); William A. Fletcher, The Structure of Standing, 98 Yale LJ. 221 (1988); Louis L. Jaffe, The Citizen As Litigant in Public Actions: The NonHohfeldian or Ideological Plaintiff, 116 U. Pa. L. Rev. 1033 (1968); Evan Tsen Lee, Deconstitutionalizing Justiciability: The Example of Mootness, 105 Harv. L. Rev. 605 (1992); Maxwell L. Stearns, Standing Back from the Forest: Justiciability and Social Choice, 83 Cal. L. Rev. 1309 (1995); Cass R. Sunstein, Standing and the Privatization of Public Law, 88 Colum. L. Rev. 1432 (1988); Mark V. Tushnet, The Sociology of Article III: A Response to Professor Brilmayer, 93 Harv. L. Rev. 1698 (1980); Winter, supra note 128. One author recently performed a LEXIS search revealing "117 articles over the last 10 years in which the term 'standing' appears in the title." Stearns, supra, at 1317 n.21.

381. See, e.g., United States v. Hays, 115 S. Ct. 2431 (1995) (denying standing to voter in racial gerrymandering case; three separate opinions filed); Lujan v. Defenders of Wildlife, 504 U.S. 555 (1992) (denying standing to environmental group in Endangered Species Act case; four separate opinions filed); Thomas v. Union Carbide Agric. Prods. Co., 473 U.S. 568 (1985) (finding sufficient ripeness in FIFRA case; three separate opinions filed); Allen v. Wright, 468 U.S. 737 (1984) (denying standing to parents of black children challenging IRS tax-exempt standards for segregated private schools; three separate opinions filed); Valley Forge Christian College v. Americans United for Separation of Church and State, Inc., 454 U.S. 464 (1982) (denying standing to group challenging government's sale of property to religious college; three separate opinions filed). 
sional law on justiciability that justifies Justice Douglas's complaint that "[g]eneralizations about standing to sue are largely worthless as such."382

The theory of adjudication as representation cannot straighten the justiciability maze. But it can provide a theoretical foundation for much of the current law in the area, and thus it can give us some clues about how to find our way out of the labyrinth. Adjudication as representation disfavors leniency in justiciability, and favors the "personal stake" requirement of existing doctrine, because it tells us that a plaintiff without a personal stake in the resolution of an issue can produce a decision that constrains in an overbroad way. So-called "ideological" plaintiffs may litigate issues in the abstract, without a firm grounding in actual facts upon which the court can rest its decision. This severely impairs the ability of later litigants to analogize or distinguish their cases from the precedential case-and thus potentially compromises interest representation. The result once more is a lack of democratic legitimacy in the constraint imposed by a precedential decision.

1. Ideological Plaintiffs and "Yes or No" Decisions. - Let us begin, again, with the second necessary condition for adjudication as representation: that a judicial decision bind only those future litigants who are similarly situated to the original litigants in a material way. ${ }^{383}$ We have seen how courts violate this condition when they range beyond the mere decision of cases to articulate general rules intended to bind future courts. Such rules take on lives of their own, constraining future litigants who are not in fact situated similarly to the litigants in the precedential case. But even where a court avoids the language of a general rule in deciding a precedential case, it may end up binding future litigants who are differently situated in material ways from the litigants before it. This can happen where a precedential case is litigated without a grounding in facts correlated to the interests of one or more of the litigants in that case-where, that is, a litigant in the precedential case is in effect vindicating not his own actual interests, but the abstract interests of other people.

To illustrate how this might occur, let us borrow and adapt an example offered by Lea Brilmayer in a groundbreaking article in which she connects justiciability doctrines to representational legitimacy in adjudication. ${ }^{384}$ Professor Brilmayer hypothesizes "a citizen in a town that has recently enacted an ordinance prohibiting the posting of campaign signs on residential property." 385 The citizen is offended by the ordinance, believing it to be a First Amendment violation. But he lacks either the de-

382. Association of Data Processing Serv. Orgs., Inc. v. Camp, 397 U.S. 150, 151 (1970). Maxwell Stearns points out that Justice Douglas's statement, which itself is a generalization, "is not self-contradictory if it is viewed not as a generalization about standing, but rather as a generalization about generalizations about standing." Stearns, supra note 380 , at 1375 n.207.

383. See supra Part II.C.

384. See Brilmayer, supra note 191, at 298-99.

385. Id. at 298. 
sire or the ability to post a sign himself-let us suppose that he lives in a high-rise apartment-and so he himself has not been and cannot be prosecuted under the ordinance. Nonetheless, the citizen, whom we will call Mr. Watchdog, files a lawsuit against the town in which he alleges that the ordinance violates the First Amendment on its face and seeks an injunction against its enforcement.

Suppose the court agrees to hear Mr. Watchdog's case. (Under current standing doctrine this possibility is unrealistic, at least in a federal court; ${ }^{386}$ but this is only a hypothetical, and indeed the unlikelihood of this situation is precisely the point.) Mr. Watchdog presents evidence that the ordinance serves no compelling government interest and would severely impair the ability of the town's citizens to express their political views. The town (let us call it Dullsville) defends itself with evidence that campaign signs detract from the natural and architectural beauty of Dullsville, thus significantly reducing the income from tourists who come to see Dullsville's stately antebellum homes, and that the signs contribute to litter and are frequent targets of unsightly vandalism. Dullsville also points out that other fora are available for its citizens to air their political views, including the Dullsville town square, which is frequently the site of political speeches and rallies.

After a bench trial, the court enters a judgment against $\mathrm{Mr}$. Watchdog and in favor of Dullsville. The court finds that the Dullsville ordinance is narrowly tailored to serve a compelling state interest, and that Dullsville citizens have adequate alternative fora in which to express their political opinions. The decision is appealed to the state supreme court, which affirms.

Now it is a year later. Another Dullsville citizen, Ms. Martyr, has been arrested under the same ordinance for posting a campaign sign on her front lawn. To make things more interesting, let us suppose that Ms. Martyr lives not in one of the old neighborhoods of Dullsville featuring lovely nineteenth-century homes, but in a modern, rather nondescript subdivision out by the shopping mall. In her misdemeanor trial for violation of the ordinance, Ms. Martyr is defending herself on the ground that the First Amendment prohibits the enforcement of the ordinance against her.

Of course, Dullsville's attorneys immediately have referred the court to the decision in Watchdog $v$. Dullsville, claiming it to be precedent with respect to Ms. Martyr's First Amendment defense. Notice the extent to which Ms. Martyr is boxed in by the Watchdog result. She can try to argue that the result does not apply to her because her home is not one of those antebellum mansions the court seemed so concerned about in Watchdog, or because she is not similarly situated to the plaintiff in Watchdog, an ideological litigant lacking a real personal stake in the issue. But these arguments are likely to be unavailing. The court in Watchdog, remember,

386. See, e.g., Hays, 115 S. Ct. 2431; Lujan, 504 U.S. 555; Allen, 468 U.S. 737. 
did not decide merely that the ordinance was constitutional as applied to the plaintiff in that case; it could not limit its decision in this way, because the ordinance had never even been applied to the plaintiff in Watchdog. Rather, the plaintiff in Watchdog had forced the court in that case to reach what in essence was a "yes or no" decision: Does the ordinance violate the First Amendment, or doesn't it? There was no room for the Watchdog court to limit its decision to the particular facts of that case, because that case had no particular facts.

Thus the defendant in People $v$. Martyr probably will not be able to distinguish Watchdog; and Ms. Martyr will be bound by that decision. She will be constrained by the result of Watchdog, that is, despite the rather salient differences between her situation and that of the Watchdog plaintiff. She will be bound illegitimately, without interest representation, and adjudication as representation will be compromised.

The plight of poor, aptly named Ms. Martyr illustrates quite starkly the implications of adjudication as representation for justiciability doctrines. Current (but much-maligned) justiciability jurisprudence generally requires, inter alia, that a plaintiff have a "personal stake" in the outcome of a case before he can be heard in court. ${ }^{387}$ In the context of standing, this means that the plaintiff must have suffered an "injury in fact"; ${ }^{388}$ in the context of ripeness, it means that the injury must be actual or imminent and not contingent or merely anticipated; 389 and in the context of mootness it means essentially that judicial relief must potentially do some good. ${ }^{390}$ The theory of adjudication as representation provides a theoretical justification for this personal stake requirement, and thus supports the idea that it should be strictly enforced. If plaintiffs are allowed to force judgments in which they have an insufficient personal stake, future litigants with actual stakes in the issue may be illegitimately bound by those judgments. This might happen where a future litigant finds herself, like Ms. Martyr, unable to distinguish a precedential case that in essence has no particular facts to distinguish.

It is worth noting in this regard the relationship between plaintiffs lacking personal stakes, or "ideological" plaintiffs, and facial challenges to statutes, that is, lawsuits asserting that a statutory provision is constitutionally invalid on its face. In a sense, the legitimacy problem in the hypothetical Dullsville litigation had more to do with the fact that $\mathrm{Mr}$. Watchdog's lawsuit forced the court to assess the facial validity of the ordinance than with the fact that Mr. Watchdog had no real personal stake in the outcome. Ms. Martyr's inability to free herself from the binding effect of the Watchdog decision stemmed from the "yes or no" breadth of that decision, not from Mr. Watchdog's ideological status. As such, adju-

387. The phrase "personal stake" comes from Baker v. Carr, 369 U.S. 186, 204 (1962).

388. See Hays, $115 \mathrm{~S}$. Ct. at 2435. (1985).

389. See, e.g., Thomas v. Union Carbide Agric. Prods. Co., 473 U.S. 568, 580-81

390. See, e.g., Lewis v. Continental Bank Corp., 494 U.S. 472, 477-82 (1990). 
dication as representation would appear to have more of a quarrel with facial challenges to statutes in general than with litigants lacking personal stakes in the outcomes of cases.

But the two issues, standing and the legitimacy of facial challenges, are intimately connected. A plaintiff with no personal stake in the outcome of a case almost inevitably will be forced to bring a facial challenge to a statute, because the statute will not have been applied to him in any way that allows the court to limit the scope of its decision. Thus, requiring plaintiffs to have personal stakes in the outcomes of cases will have the effect of severely limiting the legitimacy risk posed by broad facial challenges. Plaintiffs with personal stakes will still be able to bring facial challenges, but the court will always have the option of limiting the scope of its decision to the actual application to the plaintiff of the challenged statute. The theory of adjudication as representation suggests that the personal stake requirement can be seen at least in part as a way to limit the availability of facial challenges to statutes, whose results might bind future dissimilar litigants.

And the theory of adjudication as representation has reason to be suspicious of plaintiffs lacking personal stakes even outside the context of facial challenges to statutes. There is no reason to believe that ideological plaintiffs need be confined to constitutional and statutory litigation. A plaintiff without a personal stake could desire that the common law move in a certain direction and file a lawsuit to urge it along. A consumer advocacy group, for instance, could sue a manufacturer on a theory of strict product liability, hoping to force that manufacturer and others to incorporate better safety features into their products. If the consumer group loses the case, future litigants actually injured by unsafe products might be illegitimately bound by the decision. The theory of adjudication as representation tells us that a personal stake requirement is a good idea in these kinds of cases as well, at least from the perspective of democratic legitimacy.

Of course, there may be other good reasons, reasons not connected with democratic legitimacy, why we should relax the personal stake requirement in certain instances. Sometimes there will be a collective action problem hindering a challenge to an unconstitutional statute or some other aspect of the status quo: Every member of a certain class is being imjured in some way by the status quo, but no individual member has a sufficient interest in change to undertake the time and expense of filing a lawsuit. In such cases, ideological lawsuits may be the only way to redress widely dispersed harms. ${ }^{391}$ And, in any case, we may have some confidence that subsequent courts and litigants, faced with a precedent upholding the validity of a statute against a facial challenge, will nonetheless find ways to hold that the statute is invalid as applied in certain circumstances. But there seems reason to suppose that subsequent courts 
will not always fully succeed in doing so-that a decision rejecting a facial challenge will have at least some prejudicial effect on future litigants who really have been harmed by a statute. The theory of adjudication as representation tells us that this kind of binding effect may be illegitimate, and it therefore gives us reason to enforce standing doctrines in a fairly rigid way.

2. The Effectiveness of Ideological Plaintiffs. - In several insightful articles written in the late 1970s, Lea Brilmayer pointed to the connection between justiciability doctrines and representational legitimacy as a strong reason to deny court access to ideological plaintiffs seeking to challenge the constitutionality of statutes. In "Judicial Review, Justiciability and the Limits of the Common Law Method," Professor Brilmayer argued that the legitimacy of judicial review depends on a strict application of the "case method," that is, judicial action only in the context of concrete cases. Restricting judicial review to specific cases, she contended, ensures that "participation in the challenge [to the statute] will be limited to those persons actually suffering the statute's adverse impact." 392 This in turn preserves the legitimacy of the process with respect to later litigants, who will be free "to reargue the statute's invalidity as applied to [them] to the extent that [they] ha[ve] experienced the statute's impact in a different way." 393 The case method thus inserts a form of representational legitimacy into judicial review: The plaintiff challenging a statute can really be said to represent "all others who are in a similar position." ${ }^{94}$ Brilmayer used these observations to support her argument against expansive justiciability doctrines in constitutional cases.

Similarly, in "The Jurisprudence of Article III: Perspectives on the 'Case or Controversy' Requirement," Professor Brilmayer asserted that the "case or controversy" language of Article III can be explained in part by the desirability of protecting litigants from the binding precedential effect of decisions reached through the participation of previous litigants with insufficient personal stakes in the outcome. ${ }^{395}$ Brilmayer again noted that a litigant involved in producing a precedential decision can be said to represent future litigants who will be affected by the decision. She then suggested that a so-called "ideological" plaintiff-"a challenger [of legislation] without the traditional personal stake"396 - is not likely to be as adequate a representative of future affected parties as a "traditional plaintiff," who may be "better able vividly to illustrate the adverse effects of the complained-of activity." 397

Professor Brilmayer's representational argument against relaxation of justiciability requirements focused on the idea that ideological plain-

392. Brilmayer, supra note 176 , at 816 .

393. Id. at 816-17.

394. Id. at 817 .

395. See Brilmayer, supra note 191, at 306-10.

396. Id. at 306.

397. Id. at 309. 
tiffs, because they lack a personal stake in the outcome of a case, are unlikely to do as good a job litigating the case as a "traditional" plaintiff (or, in a criminal case, a defendant) might. She pointed, for example, to the "danger that by seeking to change the law too rapidly an ideological plaintiff will take greater risks by framing the issues in a broader, more controversial, manner."398 This argument has been criticized by Mark Tushnet, who questions Brilmayer's premises that plaintiffs are likely to pursue public interest litigation without some degree of ideological motivation $^{399}$ and that ideological plaintiffs are unlikely to litigate as effectively as traditional plaintiffs. ${ }^{400}$

But the theory of adjudication as representation gives us reason to disfavor purely ideological plaintiffs éven if Professor Tushnet's criticisms are valid. One concern of adjudication as representation seems indeed to be the adequacy of the litigants' participation at the precedential level; recall our tentative third condition of adjudication as representation, adequacy of participation. 401 But even if this concern is misplaced with respect to ideological plaintiffs, the problem of compromised interest representation remains. Think back for a moment to Ms. Martyr's hypothetical predicament. She found herself constrained by the result of Watchdog v. Dullsville despite her manifest dissimilarity to the Watchdog plaintiff. But Ms. Martyr's constraint was illegitimate irrespective of the quality of Mr. Watchdog's advocacy. Even if his advocacy was impeccable, Ms. Martyr still was constramed by a rule created by a non-interest representative. Because the ordinance had not been applied to $\mathrm{Mr}$. Watchdog personally, the Watchdog court was forced to reach a general, once-andfor-all, "yes or no" decision about the constitutionality of the ordinance, without grounding its decision in the (nonexistent) particular facts of the case. Thus subsequent litigants like Ms. Martyr were prevented from distinguishing Watchdog on its facts, and Watchdog dictated the results of their cases despite their lack of similarity to the Watchdog plaintiff.

The theory of adjudication as representation, then, supports denying justiciability even to an extremely competent and motivated ideological plaintiff. Because that theory is concerned primarily with true interest

398. Id. As support for this concern, Professor Brilmayer noted the example of Sierra Club v. Morton, 405 U.S. 727, 731-41 (1972), in which the ideological plaintiff "deliberately omitted from its complaint any allegation that its members had been injured in fact .... One suspects that its arguments would have been heard more sympathetically if it had adopted a less radical stance." Brilmayer, supra note 191, at 309 n.39. Brilmayer also cited several articles in which "[p]ublic interest lawyers [have] acknowledge[d] that these dangers exist." Id. at 309-10 \& nn. 40-41; see Gary Bellow \& Jeanne Kettleson, From Ethics to Politics: Confronting Scarcity and Fairness in Public Interest Practice, 58 B.U. L. Rev. 337 (1978); John P. Dawson, Lawyers and Involuntary Clients in Public Interest Litigation, 88 Harv. L. Rev. 849 (1975); Michael Meltsner, Litigating Against the Death Penalty: The Strategy Behind Furman, 82 Yale L.J. 1111 (1973).

399. See Tushnet, supra note 380 , at $1708-11$.

400. See id. at 1711-21.

401. See supra Part II.C. 
representation through similarity of circumstances, it rejects judicial decisions made "in the air"-without a foundation in specific facts applied to specific people, and thus without a basis upon which subsequent litigants can "choose" their representatives by the process of analogy and distinction.

3. Justiciability, the "Passive Virtues," and Broad Participation. - The theory of adjudication as representation thus speaks strongly in favor of interpreting justiciability doctrines strictly, of requiring plaintiffs in most cases $^{402}$ to have a personal stake in the outcome. This conclusion does not contradict my suggestion in a previous section ${ }^{403}$ that adjudication as representation disapproves the Bickelian "passive virtues." Justiciability should be denied when, and only when, a plaintiff does not have a sufficient personal stake in the outcome to produce a legitimately binding rule. In judicial review and statutory interpretation cases, this inquiry will focus on whether the statute in question actually has been applied to the plaintiff in a detrimental way. The determination should be made only after the court has heard reasoned arguments and, if appropriate, taken evidence presented by the parties; it should be accompanied by an opinion explaining the facts upon which it is based. The point is simply to deny adjudication in those cases where the lack of a personal stake prevents the court from basing its substantive decision on facts particular enough to allow later litigants to distinguish them.

But the passive virtues contemplate denials of justiciability on grounds of prudence, not on grounds of legitimacy. They care less about whether the plaintiff has a personal stake in the outcome of a case than about whether the issue presented by the case is politically ripe for decision, or whether the case presents the ideal set of facts for determination of an issue, or whether deciding the case will have ramifications beyond the effects upon the parties in the courtroom. ${ }^{404}$ That is, the passive virtues require the court to make the decision of whether to accept a case a strategic decision. This kind of strategic calculus undermines adjudica-

402. As Professor Brilmayer acknowledges, there certainly will be cases in which plaintiffs should be allowed to assert the rights of third parties, such as where the third party has no means of asserting the right, see Barrows v. Jackson, 346 U.S. 249 (1953) (white landowner permitted to assert equal protection rights of black purchaser of real property in defense to suit for breach of racially restrictive covenant); where the third party's rights would effectively be foreclosed by a judgment against the plaintiff, see Griswold v. Connecticut, 381 U.S. 479 (1965) (physicians permitted to assert privacy rights of patients to whom they had prescribed birth control); or where the assertion of the right by the third party would in effect render the right useless, see NAACP v. Alabama, 357 U.S. 449 (1958) (civil rights organization permitted to assert First Amendment rights of members in suit to prevent disclosure of membership list). See Brilmayer, supra note 176, at 825-26. A similar example is the "capable of repetition, yet evading review" exception to the mootness doctrine. See, e.g., International Org. of Masters, Mates \& Pilots v. Brown, 498 U.S. 466, 473 (1991).

403. See supra Part IV.B.3.

404. See generally Bickel, supra note 307, at 111-98 (discussing the courts' options and considerations in deciding whether, when, and how much to adjudicate). 
tion as representation because it is not truly based upon the proofs and reasoned arguments of the parties.

So a call for strict enforcement of justiciability doctrines is not an endorsement of the passive virtues. Nor is it a renunciation of the requirement that courts deciding constitutional cases liberally allow participation by affected parties and interest groups in addition to the original parties to the case. ${ }^{405}$ Adjudication as representation requires that a plaintiff have a personal stake in order to initiate a lawsuit; it does not require that every participant in the lawsuit have such a stake. As long as one of the litigants challenging a statute has a real personal stake in the outcome, the problem of deciding a case "in the air," with no particular facts upon which to ground the decision, should be averted, and subsequent litigants should be able to avoid constraint by non-interest representatives. Ideally, every affected interest would be represented in the litigation by someone with a true personal stake in the proceedings; but this is probably too much to ask, and the practical remedy of allowing representative interest groups to participate even absent a personal stake is at least an improvement on the lack of any such participation at all.

4. Justiciability, Separation of Powers, and Prudence. - The prevailing view, both in the commentary ${ }^{406}$ and in the case law, ${ }^{407}$ is that justiciability doctrines have two sources: (1) the constitutional principle of separation of powers as reflected in Article III; and (2) "prudent judicial administration." 408 But, as we have seen, the theory of adjudication as representation suggests a third justification for those doctrines: the preservation of democratic legitimacy in adjudication. The validity of this justification does not mean that justiciability doctrines cannot be traced to constitutional roots. As Professor Brilmayer has pointed out, ${ }^{409}$ the case or controversy requirement of Article III might be seen as a specific mechanism for ensuring that the general constitutional philosophy of democratic legitimacy applies to adjudication as well as to parliamentary lawmaking. But the doctrines have nothing to do with separation of powers, at least not as that concept traditionally is understood. Their purpose is not to prevent courts from deciding issues that should be left to legislatures, but rather to ensure that whatever issues courts do decide are decided in a democratically legitimate way.

Nor, as I have suggested, are justiciability doctrines a matter of prudence when seen from the perspective of adjudication as representation.

405. See supra Part TV.B.4.

406. See generally, e.g., Erwin Chemerinsky, Federal Jurisdiction $\S \S 2.1-2.6$, at 41-166 (2d ed. 1994); Richard H. Fallon, Jr., et al., Hart and Wechsler's The Federal Courts and the Federal System 67-98 (4th ed. 1996); Martin H. Redish, Federal Courts: Cases, Comments and Questions 16-129 (2d ed. 1989); 13 Wright et al., supra note 369, \$ 3529-3529.1, at 278-308.

407. See, e.g., Lujan v. Defenders of Wildlife, 504 U.S. 555, 559-62 (1992); Allen v. Wright, 468 U.S. 737, 750-51 (1984).

408. Chemerinsky, supra note $406, \S 2.1$, at 42 .

409. See Brilmayer, supra note 191, at $\mathbf{3 1 0}$. 
Indeed, denying justiciability for prudential reasons vitiates the operation of adjudication as representation; it binds parties to decisions that those parties have not substantially participated in creating. The theory of adjudication as representation implies that justiciability doctrines are best interpreted to ensure that cases are decided legitimately rather than to allow courts better to administer their dockets or shape the evolution of the law.

\section{CONCLUSION: AdJUDICATION AS REPRESENTATION AND "Judicial ACTIVISM"}

Disguised or not, the habit of legislating policy from the bench, once acquired, is addictive .... The activist or revisionist judge ... can no more restrain himself from doing "good" in construing a statute than when he purports to speak with the voice of the Constitution.

Robert Bork ${ }^{410}$

[T] he French jurist, Saleilles, [writes]: "One wills at the beginning the result; one finds the principle afterwards; such is the genesis of all juridical construction. ..." I would not put the case thus broadly. So sweeping a statement exaggerates the element of free volition. It ignores the factors of determinism which cabin and confine within narrow bounds the range of unfettered choice.

Benjamin Cardozo ${ }^{411}$

I began this Article with an introduction to Robert Bork's understanding of the proper judicial role, an understanding in which that role stood in sharp contrast to the role of elected legislators. I hope I have shown in the pages since then that this understanding is somewhat myopic. What Judge Bork and many others have missed is the operation of adjudication as representation and the significant measure of democratic legitimacy it provides. It is a process to which Judge Bork's antecessor on a different bench, Justice Cardozo, was not entirely blind when he wrote of "the factors of determinism which cabin and confine within narrow bounds the range of unfettered [judicial] choice."412 Cardozo, although certainly no believer in judicial impotence, ${ }^{413}$ at least perceived that the power of judicial decision was not quite the power of unbounded creation, divine or diabolical, that Judge Bork and many others have thought it to be.

410. Bork, supra note 1 , at 16 .

411. Cardozo, supra note 7 , at 170 (citation omitted).

412. Id.

413. Indeed, most of The Nature of the Judicial Process is a testament to Cardozo's vision of a powerful, self-directed judiciary. See Cardozo, supra note 7. 
In this Conclusion, I will bring the theory of adjudication to bear on the idea that perhaps bothers Judge Bork the most in The Tempting of America, an idea that grows out of Bork's fundamental distrust of a judiciary he believes to be constrained in practice only by its own conscience. The idea is judicial activism. ${ }^{414}$ As we have seen, Bork uses the phrase pejoratively, to refer to the phenomenon of courts doing what they should not be doing in a system of constitutional democracy. I want to suggest here that the idea of judicial activism, seen as a negative, is less about what courts do than about how they go about doing it - that is, that our concerns for the legitimacy of judicial decisionmaking should focus less on the substance of the decisions courts actually make and more on the processes used by courts in making those decisions. This suggestion should come as no surprise to the reader who has made it this far.

Recall that the notion of judicial activisin is animated by a fear of rule by judicial fiat, of government by Platonic Guardians. ${ }^{415}$ But the theory of adjudication as representation suggests that this fear is largely unfounded in the context of adjudication, because the premise upon which it is based-unfettered judicial power-is incorrect. In fact, as that theory tells us, courts are constrained in making their decisions. They are constrained by the factual proofs and legal arguments that have been placed before them by the litigants; they are required to work with a limited number of decisional alternatives, each of which has been authored to a significant degree by the litigants themselves. As such, their discretion is mostly confined within the realm of these alternatives and the reasons that the parties have advanced for them.

If courts are practically constrained by the mechanism of participatory adjudication, then the central question asked by critics of judicial activism like Judge Bork- "[W] ho is to protect us from the power of judges? How are we to be guarded from our guardians?"416_-loses much of its meaning. We need less protection from judicial power than antiactivists think, because judges simply have less power than anti-activists assume. The real power, or much of it, resides in the litigants. And the litigants in precedential cases, as we have seen, are in a sense "[ ] elected, [ ] accountable, and [ ]representative" 417 in a way that inany judges ${ }^{418}$ are

414. For my understanding of how the term "judicial activism" typically has been used, see supra text accompanying notes 15-26. For some other understandings of the term, see the sources cited supra note 15 .

415. See supra notes $23-26$ and accompanying text.

416. Bork, supra note 1 , at 5 .

417. Id.

418. Not, apparently, most judges. Through a survey of state constitutional provisions, Steven Croley has found that "[m]ost judgeships in the United States are elective offices." Steven P. Croley, The Majoritarian Difficulty: Elective Judiciaries and the Rule of Law, 62 U. Chi. L. Rev. 689, 690, 725-26 (1995) (emphasis added). This fact should mean that Judge Bork's fears about judicial activism do not apply to a significant portion of the adjudication actually occurring in the country today, since those fears are purportedly focused upon judges who are "unelected, unaccountable, and unrepresentative." Bork, 
not. They are "elected" through the process of participatory adjudication that occurs in future cases, when future litigants determine whether and how a precedent will bind them by presenting proofs and reasoned arguments to the court. And they are "accountable" and "representative" because, through the common law method, their interests in effectively litigating the issues coincide with those of future litigants who will be bound by their actions. Adjudication-even adjudication that invalidates democratically enacted statutes, forces the restructuring of public institutions, or otherwise seems "activist" in some sense-therefore need not be "tyranny." It can itself be democratically legitimate in a meaningful way.

Herein, of course, lies a touch of myth. Judge Bork and others are not crazy to fear judicial discretion; no one seriously doubts that the personal values of judges sometimes do creep into the activity of judicial decisionmaking. The process of adjudication as representation cannot completely elimmate the risk of this occurring. But-and this is my key point-recognizing the existence of adjudication as representation can force us to rethink the questions of just what judicial activism means and precisely in what ways we do not want judges to be "active."

What the theory of adjudication as representation suggests is that courts deciding cases are illegitimately active from a democratic perspective whenever they cause one or more of the necessary conditions of adjudication as representation to be vitiated. Recall those three conditions:419 actual, meaningful litigant participation in the decision; constraint of only those litigants similarly situated to the participating litigants in every material way; and effectiveness of litigant participation. We can disregard the third condition for present purposes, since a court vitiating the first condition necessarily will vitiate the third as well. But the first two conditions together give us a standard against which we can measure illegitimate judicial activism.

The first condition, that a judicial decision actually have been produced to a significant extent through the participation of the litigants, is vitiated to the degree that a judge's decision is based on facts and reasons other than those offered by the parties. This will happen, for instance, when a judge takes an exceptionally active managerial role in the litigation by closely supervising discovery, encouraging the paring down of legal claims and theories, suggesting potential proofs or arguments, or the like. It also will happen when a judge, explicitly or otherwise, actually grounds her decision in some rationale not advanced by either party. In such cases, a judge can be said to have been active in a way that compromises the legitimacy of the decision.

This first condition explains, in a new way, the anti-activist reaction to the idea of judges "imposing their own values" in adjudication. Judi-

supra note 1, at 5. But one senses that Bork's disregard for "the politicization of the law," id. at 2, would not disappear if it were elected judges doing the politicizing.

419. See supra Part II.C. 
cial imposition of values is indeed illegitimate, but not because it "makes" rather than "declares" the law. It is illegitimate because it is a judicial encroachment on lawmaking territory that properly is reserved for the litigants-because it is the imposition of judicial values rather than the values advanced by litigants, through reasoned proofs and arguments, as the interest representatives of future affected parties.

The importance of the first condition also might help explain the typical anti-activist distaste for extensive court involvement in the oversight of public institutions like schools and prisons, what one judge approvingly has called "remedial activism." 420 Judges handling such cases tend to take a more active role in managing the progress of the case than is usual in so-called traditional litigation. ${ }^{421}$ This active role implies a reduced role for the litigants-a smaller percentage of actual litigant authorship of the eventual decision. As such, democratic legitimacy in such cases is compromised, and charges of judicial activism have some sting.

The second necessary condition of adjudication as representation, that judicial decisions bind only similarly situated parties, also suggests some kinds of judicial conduct that are illegitimately active from the democratic point of view. That condition, as we have seen, will be vitiated to the extent that a court tries to broaden the binding scope of its decision beyond the mere result of the case. Thus, the judicial articulation of rules, multifactor tests, and even general principles can be viewed as illegitimate judicial activism because it purports to bind future parties without strict regard to similarity of situation. ${ }^{422}$ Likewise, as we also have seen, judicial willingness to expand traditional boundaries of justiciability can be viewed as illegitimately active because it can force broadly constraining "yes or no" decisions instead of fact-specific judgments. ${ }^{423}$ And failures of judicial minimalism-such as aggressive judicial invalidation of statutes in circumstances where invalidation is not absolutely necessaryamount to improper activism for the same reason. ${ }^{424}$

The force of the second condition, like that of the first, contributes to an explanation of the anti-activist attack on "remedial activism" in structural reform litigation. Not only do judges tend to act managerially in such cases, potentially violating the first condition, but the results of their decisions often have constraining effects on parties not adequately represented in the decisionmaking process. The primary effects of structural reform litigation tend to be relatively contemporaneous rather than intertemporal: They extend to a wide variety of existing nonlitigants but usually do not have strong precedential effects on future litigants. Thus, parties affected by a court decree reforming a prison would include pris-

420. See Justice, supra note 15 , at 2.

421. See generally Chayes, supra note 373, at 1302-04 (describing the difference between the judicial roles in "traditional" private litigation and public law litigation).

422. See supra Part IV.A.

423. See supra Part IV.C.

424. See supra Part IV.B. 
oners, guards, other employees, administrators, families of prisoners, and taxpayers, among others, many or most of whom will not actually have had the opportunity to participate in the litigation. This fact threatens legitimacy in light of the second condition of adjudication as representation, which demands that only represented parties be bound by a decision. If these difficulties are not remedied, structural reform litigation can indeed be seen as illegitimately "activist" in violating the second condition of adjudication as representation.

So the theory of adjudication as representation actually justifies some typical anti-activist positions, although it does so on reasoning different from that usually offered by anti-activists. But in another, fundamental sense, the theory threatens the project of anti-activism as that project most often is conceived, including by Judge Bork. Bork and other critics of judicial activism typically focus on the substance of a judicial decision, on what a court has done. A decision is condemned as activist if it decides an issue the critic believes should be left to the legislature ${ }^{425}$ or if it seems to incorporate a particular viewpoint about what the "right" or "just" (as opposed to the legally correct) resolution of an issue should be. ${ }^{426} \mathrm{~A}$ decision is activist, that is, if the decision itself is bad. But the theory of adjudication as representation does not ask us to focus on the substantive results, on the what, of adjudicative decisionmaking in this way. What is important to the theory of adjudication as representation is the how: not the actual result of a case, but the process by which that result has been achieved. As such, the theory provides no justification for criticizing the substance of a particular judicial decision as activist, at least not if judicial activism is thought to be about democratic legitimacy. It justifies only a critique of a court's process of decisionmaking.

For exainple, charges of judicial activism are often leveled when a court strikes down a democratically enacted statute; this indeed is the most frequent target of Judge Bork's criticism. ${ }^{427}$ But the theory of adjudication as representation tells us that such an act is not inherently activist on a scale of democratic legitimacy. Even the act of interpreting the Constitution incorrectly to strike down a statute is not illegitimate activism from a democratic perspective: If judicial minimalism has been adhered to and broad participation has been allowed, that incorrect interpretation is in fact the product of a democratic decisionmaking process. Such a decision may be illegitimate on other grounds-"metademocratic" reasons of constitutional supremacy, for instance-but it is not illegitimate for the reason advanced by Judge Bork and other opponents of judicial activism, that is, because it is performed by judges who are "unelected, unaccountable, and unrepresentative."428 From the standpoint of democracy, such decisions are illegitimate only if they have been reached by

425. See, e.g., Bork, supra note 1, at 3-4 (discussing Roe v. Wade).

426. See, e.g., id. at 2-3.

427. See id. at 17.

428. Id. at 5 . 
some other process than adjudication as representation. In Judge Bork's own words, their "democratic integrity ... depends entirely upon the degree to which [their] processes are legitimate." 429

Thus the theory of adjudication as representation suggests that the debate about judicial activism should be refocused. The substance of judicial decisions-what a court has decided-can, of course, be criticized, but grounding such a critique in charges of judicial activism misses the point. Judicial activism, if it is truly illegitimate from a democratic perspective, is illegitimate because it has compromised the process, not the substance, of judicial decisionmaking. Activism is a problem of how decisions are made, not of what those decisions look like or what their effects may be.

$* * * * *$

At bottom, what I have called the theory of adjudication as representation is remarkably elementary, even obvious-almost unworthy of the appellation "theory." It says simply that when adjudication operates as that process often, perhaps even usually does, according to the common law method that it has known for centuries, it brings with it the ingredients of a truly democratic legitimacy. And it tells us that all we have to do in order to sustain that legitimacy in adjudication is to preserve the common law features that produce it: resolution only of actual controversies; fact-specific, case-by-case adjudication; initiation and control of lawsuits by affected parties; and narrow application of stare decisis.

My method in this Article has been a combination of description and justification, akin to John Rawls's technique of "reflective equilibrium."430 It has not been history. I have not tried to demonstrate that adjudication as representation has developed historically as a means of injecting democratic legitimacy into the adjudicative process, nor do I believe it is necessary to demonstrate that. It may well be that our current process of adjudication evolved, like democratic processes of parliamentary lawmaking, in continuing response to the liberal demands for ever-greater individual autonomy and involvement in government decisionmaking.431 But where adjudication as representation came from does not matter. What matters is that it exists and that it results in a measure of democratic legitimacy.

Of course, democratic legitimacy may not be the whole story. We live not just in a democracy, but in a constitutional democracy; this fact implies a commitment to metademocratic rule on some issues, to decisionmaking on another level entirely than the level of contemporaneous individual participation and majority rule. It is possible that the everyday

429. Id. at 2.

430. See John Rawls, Political Liberalism 8-9, 96-97 (1993); John Rawls, A Theory of Justice 20-21, 48-51 (1971).

431. Such an evolution is suggested by a reading of Yeazell, supra note 190 . 
democratic legitimacy of adjudication may sometimes have to be sacrificed in the name of metademocratic, constitutional legitimacy. Perhaps we do not want individual litigants to play a dominant role in determining what the Constitution means; perhaps we would rather have that role played by unelected judges. The theory of adjudication as representation cannot tell us how to resolve such a question. Nor can it tell us whether, or when, other considerations-pragmatic criteria like consistency, perhaps, or a need to preserve democracy in the long run by sacrificing it in the particular case-might outweigh the value of democratic legitimacy in adjudication.

What the theory can do is challenge the usual assumption that constraint by judicial decision is, inherently, a nondemocratic constraint. In doing so, it might also challenge other, more specific assumptions: that the debate over judicially articulated rules is simply a debate about utility, for instance; that justiciability doctrines have primarily to do with separation of powers or prudent judicial administration; and that judicial review ultimately means rule by an unelected, unrepresentative judiciary. And the theory might subtly change the nature of our anxiety about adjudication, causing us to worry a little less about the substantive legitimacy of judicial decisions and a little more about the legitimacy of the processes used to reach them.

In short, if the theory of adjudication as representation tells us anything, it is that a fundamental concern for process in adjudication, or in any kind of social decisionmaking, is not just an elevation of style over substance. Process is the engine of legitimacy in a democratic government, even if process is viewed from a functionalist perspective, as the means to an end. It is the participatory process of decisionmaking in a democracy that makes that form of government distinct and gives it special value. The fact that a government decision is made in a courtroom rather than an assembly hall does not exempt that decision from the basic democratic requirement of procedural legitimacy. 